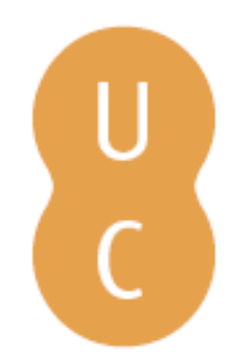

\title{
pompalina
}

\section{Vidas Paralelas: Alcibíades e Coriolano}

Autor(es): $\quad$ Plutarco Publicado por: Imprensa da Universidade de Coimbra; Centro de Estudos Clássicos e

URL

persistente: URI:http://hdl.handle.net/10316.2/2391

DOI: $\quad$ DOI:http://dx.doi.org/10.14195/978-989-8281-55-5

Accessed : $\quad$ 26-Apr-2023 10:34:00

A navegação consulta e descarregamento dos títulos inseridos nas Bibliotecas Digitais UC Digitalis, UC Pombalina e UC Impactum, pressupõem a aceitação plena e sem reservas dos Termos e Condições de Uso destas Bibliotecas Digitais, disponíveis em https://digitalis.uc.pt/pt-pt/termos.

Conforme exposto nos referidos Termos e Condições de Uso, o descarregamento de títulos de acesso restrito requer uma licença válida de autorização devendo o utilizador aceder ao(s) documento(s) a partir de um endereço de IP da instituição detentora da supramencionada licença.

Ao utilizador é apenas permitido o descarregamento para uso pessoal, pelo que o emprego do(s) título(s) descarregado(s) para outro fim, designadamente comercial, carece de autorização do respetivo autor ou editor da obra.

Na medida em que todas as obras da UC Digitalis se encontram protegidas pelo Código do Direito de Autor e Direitos Conexos e demais legislação aplicável, toda a cópia, parcial ou total, deste documento, nos casos em que é legalmente admitida, deverá conter ou fazer-se acompanhar por este aviso.

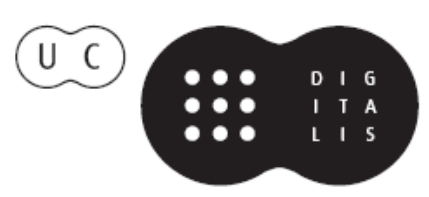




\section{Plutarco}

\section{Vidas Paralelas}

\section{Alcibíades}

Coriolano

TRADUÇÃO DO GREGO, INTRODUÇÃO E NOTAS Maria do Céu Fialho e Nuno Simões Rodrigues 
Série "Autores Gregos e Latinos -

TRADUÇÃO, INTRODUÇÁO E COMENTÁRIO”

ISSN: 2183-220X

Apresentação: Esta série procura apresentar em língua portuguesa obras de autores gregos, latinos e neolatinos, em tradução feita diretamente a partir da língua original. Além da tradução, todos os volumes são também caraterizados por conterem estudos introdutórios, bibliografia crítica e notas. Reforça-se, assim, a originalidade científica e o alcance da série, cumprindo o duplo objetivo de tornar acessíveis textos clássicos, medievais e renascentistas a leitores que náo dominam as línguas antigas em que foram escritos. Também do ponto de vista da reflexão académica, a coleçáo se reveste no panorama lusófono de particular importância, pois proporciona contributos originais numa área de investigaçáo científica fundamental no universo geral do conhecimento e divulgaçáo do património literário da Humanidade. 
(Página deixada propositadamente em branco) 
(Página deixada propositadamente em branco) 


\section{Plutarco}

\section{Vidas Paralelas: \\ Alcibiades e Coriolano}

TraduÇÃo do GREgo, INTROdUÇÃo E NOTAS DE

Maria do CÉu Fialho

Universidade de Coimbra

Nuno Simốes Rodrigues

Universidade de Lisboa

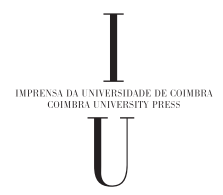


Todos os Volumes desta SÉRIE SÃo SUJeITOS A ARbitragem CIENTÍFICA INDEPENDENTE.

Título - Vidas Paralelas - Alcibíades e Coriolano.

Tradução do grego, introduçāo e notas: Maria do Céu Fialho e Nuno Simóes Rodrigues

Autor - Plutarco

Série Autores Gregos e Latinos - Textos

Coordenador Científico do plano de edição: Maria do Céu Fialho

Conselho Editorial

José Ribeiro Ferreira

Francisco de Oliveira

Maria de Fátima Silva

Nair Castro Soares

Director Técnico: Delfim Leão

\section{Obra realizada no Âmbito das actividades da UI\&D \\ Centro de Estudos Clássicos e Humanísticos}

\section{EDIÇÃo}

Imprensa da Universidade de Coimbra

URL: http://www.uc.pt/imprensa_uc

E-mail: imprensa@uc.pt

Vendas online:

http://www.livrariadaimprensa.com

\section{CoORdenAÇÃo EDITORIAL}

Imprensa da Universidade de Coimbra

Concepçấo gráfica \& Paginação

Rodolfo Lopes \& Nelson Henrique

Pré-IMPREssão

Imprensa da Universidade de Coimbra

\author{
Impressáo e ACABAmento \\ www.artipol.net
}

ISBN

978-989-26-0278-3

ISBN DigitaL

978-989-26-0289-9

\section{DOI}

http://dx.doi.org/10.14195/978-989-8281-55-5

\section{Depósito Legal \\ $346986 / 12$}

1a EdiçÃo: CECH・2010

2a EDIÇÃO: IUC • 2012

(C) JULHO 2012.

IMPRENSA dA UNIVERSIDADE DE CoImbra

Classica Digitalia Vniversitatis Conimbrigensis (http://classicadigitalia.uc.pt)

Centro de Estudos Clássicos e Humanísticos da Universidade de Coimbra

Reservados todos os direitos. Nos termos legais fica expressamente proibida a reprodução total ou parcial por qualquer meio, em papel ou em edição electrónica, sem autorizaçáo expressa dos titulares dos direitos. É desde já excepcionada a utilização em circuitos académicos fechados para apoio a leccionação ou extensâo cultural por via de e-learning. 


\section{ÍNDICE}

INTRODUÇÃO GERAL

Vida de Alcibíades

INTRODUÇÃO

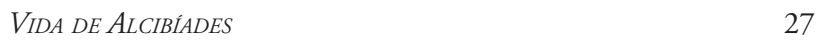

Vida de Coriolano

$\begin{array}{lr}\text { INTRODUÇÃO } & 99\end{array}$

VIDA DE CORIOLANO 117

COMPARAÇÁO ENTRE ALCIBÍADES E CORIOLANO 179

$\begin{array}{lr}\text { Biblografia } & 189\end{array}$

$\begin{array}{ll}\text { ÍNDICE DE NOMES } & 197\end{array}$ 
(Página deixada propositadamente em branco) 


\section{INTRODUÇÃO GERAL}

Ao pôr em paralelo o percurso biográfico de Alcibíades e de Coriolano, Plutarco escolheu duas figuras, uma grega, outra romana, de contextos históricos não muito similares. Alcibíades pertence ao contexto de uma democracia em crise, numa Hélade em vésperas de se lançar na guerra civil generalizada ou já envolvida nela - a Guerra do Peloponeso - em que, inclusivamente, o velho inimigo persa era visto como aliado possível para ajudar a enfraquecer a facção grega contrária. Coriolano, por seu turno, pertence aos primórdios da República, numa Roma pré-helénica. A figura do primeiro tem contornos históricos nítidos, enquanto na do segundo se esbatem a História e os contornos lendários. Ambos ficaramórfãos demasiadocedo, na infância, distinguindo-se Alcibíades pelo refinamento da sua educação. Mas a essa paideia refinada corresponde uma capacidade camaleónica (a imagem é de Plutarco) de adaptação às circunstâncias, enquanto Coriolano, na sua dureza e intransigência, deixa transparecer, pela negativa, traços do ancestral perfil do Romano. A inegável coragem de ambos não foi sempre posta ao serviço da pátria. Mal compreendidos ou ressentidos com os seus concidadáos, ambos vieram a representar uma ameaça para as respectivas pátrias, aliando-se, respectivamente com Espartanos ou Persas, ou com os Volscos, para granjear a sobrevivência ou a vingança. 
O começo da biografia de Coriolano prepara já a synkrisis entre as duas Vitae, na medida em que responde, de alguma forma, ao paralelismo entre a infância das duas personagens. Coriolano também ficou órfăo de pai na infância, mas manteve sempre, em relação à mãe, um grande afecto. Em Alcibiades não se fala, à partida, de afectos, mas de grupos de jovens que rodeavam o protagonista e o seguiam. A Coriolano faltou-lhe a presença vigorosa de um pai e a educação que desenvolvesse as virtudes do seu carácter e inteligência, refreando os defeitos e impulsos, como a cólera, a que era propenso, e a arrogância. Com a bela imagem de matriz platónica ${ }^{1}$ realça Plutarco o papel necessário que a educação exerce sobre as naturezas nobres e os caracteres potencialmente bons (Cor.1.2-3):

Órfão de pai, Gaio Márcio (pois é sobre ele que aqui se escreve) foi educado pela mãe viúva, provando que a orfandade, apesar de ter coisas desagradáveis, não impede que se venha a ser um homem virtuoso e que se distinga da maioria, ainda que alguns, mesquinhos, a responsabilizem e culpem pela corrupção, tendo em conta a negligência com que supostamente terão sido tratados. Este mesmo homem deu testemunho dos que acreditam que a natureza, ainda que nobre e boa, se for desprovida de educação, produz muitas coisas boas, mas também más, tal como acontece na agricultura, quando um terreno fértil é deixado ao abandono e sem cuidados.

Estas consideraçóes constituem uma espécie de resposta ao itinerário de juventude de Alcibíades. Este,

${ }^{1}$ Ver Platáo, República 491 d-e. 
em contrapartida, teve tutores de prestígio, teve quem se ocupasse da sua educação e, sobretudo, contou com a dedicação de Sócrates, empenhado em fazer desabrochar o que de melhor havia no jovem. $\mathrm{O}$ que, à partida, se pode considerar o ethos potencial de Alcibíades, com as boas e más qualidades que exigiam a intervenção de um educador, mas também o esforço do próprio, foi sendo sujeito a agentes externos contraditórios, de modo a que o que de pior havia em Alcibíades prevaleceu, como resposta a um destes tipos de agentes.

No espírito e conduta de ambos vislumbrou Plutarco a presença de traços da tirania que sempre póe em perigo o equilíbrio e destino de uma comunidade (ainda que, em alguns momentos, os rasgos de patriotismo falassem mais alto).

Imitando o ritmo da oscilação deste carácter e do seu destino, Plutarco conclui a comparação das Vitae de Alcibíades e Coriolano com um desfecho teatral: começa por estabelecer um paralelismo que aparenta ser favorável em aptidóes a Alcibíades sobre Coriolano para no fim, inesperadamente, operar um volte-face e concluir que a philotimia de Coriolano foi redimida pela sua sophrosyne e pelo desprendimento em relação às riquezas, enquanto Alcibíades se revelou como o homem mais destituído de escrúpulos e mais destituído de sentido moral - to kalon.

A tradição manuscrita não é unânime quanto à ordenaçáo deste par de Vitae - o que tem paralelo nas actuais ediçóes. Ainda que pareça ser mais forte a tradição que faz anteceder Coriolano a Alcibíades 
(quiçá por motivos de cronologia relativa), entendemos, não havendo unanimidade na tradição e, estando este volume integrado numa série de publicaçôes das Vidas em tradução, em que a grega antecede a romana, respeitar essa mesma ordenação no que toca aos biografados Alcibíades e Coriolano².

Para a tradução destas Vitae, usámos como texto base a lição de K. Ziegler, Plutarchi Vitae Parallelae (recognouerunt $\mathrm{Cl}$. Lindskog et $\mathrm{K}$. Ziegler, da colecção Bibliotheca Scriptorum Graecorum et Romanorum Teubneriana), publicada em Leipzig pela casa B. G. Teubner, em 1959.

Finalmente, deixamos explícito o nosso agradecimento ao Coordenador Científico do Projecto "Plutarco e os fundamentos da Identidade Europeia", o nosso Colega Doutor Delfim Ferreira Leão, pelo interesse manifestado e apoio prestado à publicação deste volume, traduzidos, inclusivamente, na cuidadosa revisão de texto e em sugestóes dadas.

${ }^{2}$ Sobre este assunto veja-se Pérez JimÉneZ (2006) 10-11. 
Vida de Alcibíades 
(Página deixada propositadamente em branco) 


\section{INTRODUÇÃO}

Em muitas das Vitae de Plutarco apercebemo-nos de uma espécie de tensão agonística entre valores naturais, que se deixam adivinhar nas potencialidades que o seu carácter parece revelar à partida, e estímulos externos ou contingências que, muitas vezes, póem à prova e se sobrepóem a essa natureza promissora. Do resultado dessa luta, seja ele já perceptível na juventude, ou na maturidade ou no fim da vida, decorre a configuração final do ethos do herói.

Neste contexto revela-se particularmente interessante o caso da Vida de Alcibiades. Sobre esta fascinante e polémica figura afirma Plutarco (4.2.) curiosamente no mesmo capítulo inicial em que refere, de forma enfática, a força positiva da presença de Sócrates:

É que não há outro homem a quem a fortuna (tyche) tenha envolvido e rodeado de um tal conspecto de atributos, para o tornar invulnerável à filosofia..."

O capítulo citado pertence ao conjunto de capítulos iniciais que se ocupam, de modo aparentemente desordenado, da ascendência e de episódios da infância e adolescência desta figura.

Nascido, como o atesta Plutarco, das mais ilustres famílias atenienses em 451 a. C., dotado de inteligência, 
beleza, força e coragem, capacidade de sedução e dotes oratórios, além de um sentido estratégico apurado e uma pronta capacidade de resposta às situaçôes, vem a morrer, fora da pátria e acossado por várias facçóes, incluindo os seus compatriotas, em 404 a. C. Foi responsável pelas campanhas atenienses de maior êxito na Guerra do Peloponeso, mas igualmente responsável pelos reveses que a sua cidade pátria sofreu. É que aos dotes naturais correspondiam características que os moldavam e conduziam, muitas vezes, no sentido das piores condutas. Alcibíades ficou conhecido como alguém de vaidade desmedida, de extrema ambição, a que se associava a procura incontida de notoriedade. A propensão para o excesso determinou a sua vida dissoluta, rodeado de amantes, entregue à bebida e à influência de aduladores. Estes traços negativos, potenciados por factores de ordem externa, levaram a que a influência filosófico-pedagógica de Sócrates ${ }^{1}$, que nele soube vislumbrar o que havia de virtude e potencial congénito, se esbatesse e fosse anulada, como se a Tyche ${ }^{2}$, como um vento, arredasse o filósofo e envolvesse o jovem por essa nuvem de agentes de dissolução.

A sua existência agitada e instável é imagem da da própria pólis ateniense do tempo da sua maturidade, envolvida na Guerra do Peloponeso, onde se jogaram interesses, alianças, sediçóes e traiçóes que levaram Atenas da hegemonia à queda e perda da democracia de que tanto se orgulhava. Se os cidadáos temiam os

${ }^{1}$ BeCCHi (1999) 25-43.

2 Pérez Jiménez (1973) 103 sqq. 
traços que, em Alcibíades, poderiam denunciar a sua propensão para a tirania, foi, contudo, sem Alcibíades, que sofreram a experiência tirânica imposta pelos inimigos, no final da guerra.

Não admira, pois, que a figura de Alcibíades tivesse atraído a inveja dos seus contemporâneos e que, mediante acusaçóes de fundamento nebuloso, tivessem querido anular a sua preponderância para, depois, lamentarem o facto de, com isso, o terem empurrado para a facção inimiga.

O fascínio que esta personagem exerceu na Antiguidade e continua a exercer até nós está comprovado pelo número de autores antigos, quer contemporâneos quer posteriores, que lhe devotaram atenção, na sua obra: Aristófanes, Tucídides, Xenofonte, Platão, Teofrasto, a filosofia de tradição platónica, estóicos como Zenão e Cleantes, oradores diversos ${ }^{3}$, historiógrafos dos sécs. IV e III a. C., historiadores romanos, autores de literatura biográfica, de que distingo Cornélio Nepos, e, não esquecer, Plutarco ${ }^{4}$.

Náo encontramos nesta biografia propriamente um prólogo 5 . Plutarco entra directamente no assunto: Alcibíades descende de heróis da saga épica, ao mesmo tempo que a linha materna o liga aos Alcmeónidas. Seu pai combateu os Persas em Artemísio e os Beócios em Coroneia, onde morreu. Péricles e Arífron foram

${ }^{3}$ Vide Calvo Martínez (2004) 37-48.

${ }^{4}$ Para informação mais analítica vide PéRez Jiménez (2006) 20-21.

${ }^{5}$ StAdTER (1988) 275-295 distingue duas espécies de prólogos, nas Vitae de Plutarco, e inclui o da presente Vita no grupo dos prólogos integrados. 
seus tutores, teve uma mulher da Lacónia como ama e como pedagogo um homem chamado Zópiro. Plutarco antecipa aqui, como uma espécie de determinante da futura sorte de Alcibíades, o papel da presença de Sócrates na sua vida: foi a eunoia e a philanthropia do filósofo que contribuiram substancialmente para a doxa de que o jovem viria a gozar (1.3.).

Da sua beleza física imperecível, que o acompanhou até à morte, Plutarco passa para a referência às inconsistências de carácter reveladas na idade adulta e que relaciona com pragmasi megalois kai tychais polytropois (2.1.). O autor sublinha, nestas consideraçóes prolépticas, como se viria a reconhecer em Alcibíades um philoneikos e philoprotos, para regressar à sua infância e juventude e ilustrar, com breves anedotas, o carácter que já se anunciava. A sua rebeldia para com os mestres denuncia até que ponto este jovem promissor é avesso à influência da educação e sabe desde cedo, por intuição, jogar com as circunstâncias e manipular, servindo-se dos seus dotes. Mostra Th. Duff ${ }^{6}$ até que ponto esta ordenação aparentemente caótica dos capítulos iniciais da vida de Alcibíades contém uma semiótica própria. Plutarco joga com uma espécie de prefiguração do que será a própria anarquia da vida do biografado, embora os episódios relatados corroborem a sua extrema e incrível capacidade de resposta rápida às situaçôes e o seu arrojo. Uma leitura mais superficial deixaria o leitor criar expectativas de estar perante um indivíduo genial - que o era - de quem se poderia vir a esperar um brilhante futuro.

${ }^{6}$ Duff (2003) 94 sqq. 
Do mesmo modo, o fim da vida de Alcibíades condensa, numa espécie de simbologia, a síntese da sua própria existência: é um fim envolto em incerteza, polémico, escandaloso e ambíguo pela própria cosmética feminina com que aparece no seu sonho premonitório e pelas vestes de cortesã com que, por fim, Timandra o cobre.

A ambiguidade remete para o episódio de juventude de luta livre com o adversário, que o acusa de recorrer a processos pouco ortodoxos (2.2.) ${ }^{7}$ :

Tu mordes, ó Alcibiades, tal e qual como as mulheres!

O processo de condensação simbólica constitui um recurso de escrita do gosto de Plutarco, para tornar mais forte o poder de sugestáo do quadro final sobre o percurso que a ele leva. Outros desfechos de biografias o ilustram, como, por exemplo, o da de Teseu, de Catáo de Útica ou de César. Esta última envolve na narrativa o fim do assassinado, do assassino e da república romana. Diga-se, de passagem, que se trata de um recurso próprio da narrativa poética e que provoca, por parte do leitor, uma adesáo ao texto que está para além da razão e que se prende com os efeitos de sugestão e representação próprios da poiesis.

As relaçóes de sangue de Alcibíades ligam-no aos Alcmeónidas, simultaneamente ilustres e ligados a um caso passado de sacrilégio. A coragem do pai parece ser

${ }^{7}$ Duff (2003) 96 sq., Pérez Jiménez (2006) 132, n.13 apontam a ambiguidade sexual, contida neste episódio, que prefigura já a ambiguidade sexual que pautará a conduta futura de Alcibíades. 
espelho dos futuros feitos militares do filho. Não deixa de ser expressivo, no discurso de Plutarco, dar aquele como combatente contra Persas e contra Gregos, assim como anotar o papel de tutor de Péricles, cuja influência e exemplo parece nada ter significado para o jovem, em simultâneo com um pormenor aparentemente insignificante: o da ama, oriunda de um espaço ligado a Esparta.

Por outro lado, o registo da beleza física antecede consideraçóes sobre o ethos de alguém que parece preso não só das alteraçóes da fortuna, mas da sua própria beleza, que o condiciona a ser admirado e assediado sem ter estrutura ética para resistir à pressão desse assédio. Alcibíades apresenta-se, à partida, condicionado por essa beleza, pelo arrojo demonstrado, por um carácter fraco e volúvel e por uma inteligência brilhante a desempenhar um agitado protagonismo na vida de Atenas. Frequentemente utiliza Plutarco a conjugação tolma kai synesis para definir esses actos de arrojo que vão da infância ao fim da vida. Não é andreia o termo escolhido - mas este é o termo que Plutarco selecciona, em contrapartida, para designar a coragem de Coriolano e sublinha, na biografia correspondente, que este termo equivale ao que os Romanos designam por arete. Isto é, adivinhamos no grego do autor o esforço de equiparação ao latim uirtus. Com ela se conjugam a temperança e o sentido de justiça (enkrateia kai dikaiosyne). O lado negativo do seu carácter reside na extrema arrogância e orgulho que o hão-de perder. 
Por um lado, considere-se o conjunto daqueles que admiravam o corpo e manifestaçōes físicas de Alcibíades - os aduladores, os jovens movidos pelo impulso de um eros físico, que nele exacerbavam o desejo de satisfazer o prazer imediato. A este estímulo facilmente se associa o prazer do vinho e a embriaguez, a imoderação nos banquetes e na vida pública, a procura da glória fácil, ainda que com o sacrifício da coerência, da correcção ética, do bem da cidade. $\mathrm{O}$ episódio relatado por Plutarco em 4.5 serve como que de pórtico a um historial de atitudes de insolência e prepotência de Alcibíades, manifestadas no espaço de convívio social, como é o do banquete, provocadas pela imoderação na bebida e pela consciência de que as pessoas que humilha estão sob o império do fascínio que ele exerce, como é o caso de Ânito ${ }^{8}$.

A intervenção de Alcibíades a meio do banquete do antagonista de Sócrates recorda um outro Banquete, o de Platâo, onde a problemática de eros é discutida e em que Alcibíades, chegando também com atraso, manifesta não estar apto a passar além do plano da erótica do mundo sensível.

A corrupção de Alcibíades arrasta a corrupção de companheiros da sua geração. E se as adversidades da Tyche podem funcionar como uma espécie de teste de carácter, enfraquecê-lo mas também fortificá-lo, no caso de Alcibíades o factor Tyche, como se pode ver no passo acima referido (4.2), por lhe ter sido excepcionalmente favorável, não o pôs à prova e arredou-o da disposição

${ }^{8}$ Vide Cerezo Magán (1999) 171-180. 
de alma para reconhecer as limitaçóes do humano e a necessidade de uma reflexão filosófica e da adesão a uma filosofia prática.

De facto, as alusóes à presença de Sócrates estão contidas nesta primeira fase da vida do jovem e aparecem intencionalmente entremeadas com os desmandos do protagonista. A referência à relação erótica física com Ânito, fonte de arrogância e desequilíbrio para Alcibíades (4.5), aparece antecedida da referência ao eros de Sócrates por Alcibíades, ao qual se contrapóe (4.1). É que este representa o eros direccionado para as qualidades inatas, que se dedica a ajudar a desenvolver na alma do eroumenos. Numa espécie de vivência caótica, Sócrates representa a voz da Filosofia, o apelo da ordem e à ordem da alma, pela askesis de uma filosofia prática que faz desenvolver no indivíduo o amor ao Belo e ao Bom, nunca separando eticamente aquele deste. Mas Sócrates constituia uma excepção. Apenas Sócrates, pela visão privilegiada de um daimonios ${ }^{9}$ que depurou a capacidade de ver através do desprendimento do plano do material ao cultivar a verdadeira Filosofia como modo de vida verdadeiro, podia vislumbrar as qualidades, em estado seminal, que existiam na alma de Alcibíades e que era urgente fazer frutificar. Este constitui o segundo agente que luta por anular o primeiro de que se falou. No entanto, a estratégia das referências à acção e às intençôes de Sócrates faz perceber que a sua acção se tornará ineficaz, sobre um jovem envolvido por

9 Sobre a tradição, na filosofia e literatura antigas, do Sócrates daimonios vide Hershbell (1988) 365-382. 
um turbilhão de estímulos que apelam para o que de pior há em si, reforçados por uma tyche em aparência excepcionalmente favorável, como se vê em 4.1.

Segue-se a referência à tyche excepcional, que tornou o jovem "invulnerável à filosofia”, como antecipação, à maneira da tragédia esquiliana, entremeada no discurso sobre a influência de Sócrates na sua pessoa e a atracção por Sócrates, que o levava a ouvi-lo com encanto, com quem ouve um amante, e a tornar-se companheiro habitual do filósofo, desprezando "amantes ricos e famosos". Terá Alcibíades sido alguma vez verdadeiramente tocado pela sabedoria socrática? A planta frágil possuia qualidades para isso, mas o campo em que nasceu (antecipando a imagem da Vita de Coriolano) e todas as condiçóes adversas ao seu crescimento tornaram vã a acção de Sócrates. É o que Plutarco pretende mostrar à partida com a organização do seu discurso. Mais tarde será mais explícito, ao referir ten tes physeos anomalian deste homem (16.6). Nem o próprio Alcibíades se apercebeu, na fase de proximidade de Sócrates, que a acção benfazeja do génio filosófico não encontrava verdadeiramente condiçóes para exercer a sua eficácia (4.3-4).

Segue-se de imediato o episódio da embriaguez e excessos no banquete de Ânito.

A partir daí, o motivo da acção de Sócrates é tratado por Plutarco com uma hábil expressividade, de modo a deixar perceber que a influência do filósofo em Alcibíades se vai progressivamente perdendo, como se o crescimento desse rebento com potencialidades, na alma do jovem, fosse asfixiado por ervas daninhas (6.1). 
Não é já a imagem do amor, segundo Platão, que Alcibíades sente que Sócrates nele consegue despertar, mas o medo e a reverência, de que tenta escapar, enquanto o filósofo tenta, já em vão, exercer o seu múnus sobre esta alma prestes a perder-se no turbilhão dos prazeres. A eficácia da influência de Sócrates é agora posta a par da dos aduladores, como seus rivais; não é já constante e não se impóe pela sedução natural. Expressiva é a imagem do escravo fugitivo.

O retrato de Sócrates, como um ser excepcional, assistido pelo daimon (17.4), como só o pode ser alguém que cultiva em tão alto grau a filosofia prática e a ela conduz os seus formandos, está em perfeita sintonia com a visão tida com respeito a Sócrates na época de Plutarco e com o próprio tratamento da figura em outras obras de Plutarco, sob influência do modelo dos diálogos platónicos. O seu De genio Socratis, em especial, é perceptível em vários passos das diferentes Vitae ${ }^{10}$.

AúltimatentativadeSócrates parafazerdesabrochar o sentido dos valores, em Alcibíades, é já uma tentativa de recurso extremo, na sequência da batalha de Potideia, para que o mérito que verdadeiramente cabia ao próprio Socrates, mais do que a Alcibíades, fosse reconhecido a este. Comenta Plutarco (7.5):

O prémio de mérito cabia, com toda a justiça, a Sócrates. No entanto, como os generais mostravam o desejo de distinguir Alcibiades com esta honra, em virtude da sua alta posição,

${ }^{10}$ Platão e Xenofonte desempenharam um papel determinante para a posterior imagem de Sócrates na Antiguidade. Sobre o caso específico de Plutarco veja-se Hershbell (1988) 365-382. 
Sócrates, que pretendia estimular no jovem a ambição de praticar acçóes belas (to philotimon en tois kalois), foi $o$ primeiro a testemunhar em seu favor...

Isto é, o filósofo faz um apelo desesperado a algo que é, em Plutarco, negativamente valorizado a philotimia - e que constitui um traço de carácter acentuado em Alcibíades, para o direccionar para as boas acções e, assim, para o que é belo, sendo bom ${ }^{11}$.

$\mathrm{Na}$ retirada dos Gregos em Délio, a retirada de Sócrates, ainda que protegida por Alcibíades, quase assume o valor simbólico da saída do filósofo da vida deste homem.

Toda esta tensão de forças parece traduzir-se estilisticamente no jogo de palavras compostas, no grego, com o radical phil-: à philanthropia de Sócrates (1.2) ficou a dever um contributo fundamental para a sua fama (doxa), mas o facto de se manifestar, desde cedo, philoneikos e philoprotos (2.1), fizeram-lhe alcançar fama fácil e protagonismo sem virtude, de modo a se tornar impenetrável à philosophia do mestre (4.2). Sócrates diagnostica nele uma philotimia que tenta encaminhar para o eticamente correcto, mas em vão o faz. Essa philotimia desenvolver-se-á com a adulação, com a consciência dos seus dotes naturais, o pendor para o excesso e a prepotência, com a sua sorte favorável, a ponto de os cidadãos de boa reputação a encararem como um perigo, já que facilmente se poderia associar à tirania

${ }^{11}$ Sobre as acepçóes positivas ou negativas do termo, consoante os contextos e outros termos a que figura associado vide FIalHo (2008) 114 n. 11 e Frazier (1988) 109-127. 
(16.1-2). No vulgo Alcibíades desperta sentimentos tão contraditórios quanto a sua própria natureza, já que é amado, odiado, e a sua presença desejada.

No contexto de uma Hélade em profunda crise, que se digladia e em que a sorte e o poder, na guerra, facilmente se alteram e favorecem uns ou outros, Alcibíades aprende, por essa mesma incontrolável ambição e sede de protagonismo, a mudar facilmente de lado e a facilmente persuadir os aliados de momento ou a traí-los, se oportuno, usando a sua synesis kai tolme ("inteligência e audácia”, 35.2). Com igual facilidade assume, ou melhor, o comportamento honesto e o desonesto, a prática do excesso e os hábitos de pompa, entre os Persas, como os costumes mais sóbrios e severos, entre Espartanos. Tudo isto em função da ambição e do proveito. Para o vulgo, esta volúvel e genial adaptação às circunstâncias mantém o risco de poder despertar o sonho da tirania (35.1). Para Plutarco, esta aberraçáo monstruosa de carácter, que se vai agravando com a própria crise da Hélade, assume características comparáveis às de um animal, rastejante o camaleão (23.3).

Assim, este homem que teve a capacidade de dividir e desestabilizar todo o Peloponeso, que anulou o esforço pacificador de Nícias, converteu-se numa espécie de corporização da própria crise, de materialização do espírito do tempo. Se a ordem da cidade algum paralelismo tem com a ordem da alma, a anomalia de uma physis que Sócrates não conseguiu modelar está em consonância com uma Atenas ao sabor de maiorias movidas pela tiranização de impulsos. É esse o contexto 
em que se multiplicam os demagogos e os chefes sem escrúpulos, os senhores da guerra, que dela tiram proveito. Assim o frágil rebento da virtude secou, para dar lugar, cada vez mais evidente, aos movimentos do camaleão.

A sua morte é o quadro que melhor ilustra a sua vida: vítima dos temores da ameaça da tirania que ele representava e dos sentimentos contraditórios que a sua doxa despertava, vítima das intrigas que semeou, envolvido, ambiguamente, em roupas de cortesã, ou pura e simplesmente apanhado em fuga depois de saciar o seu eros. 
(Página deixada propositadamente em branco) 
VIDA DE ALCIBÍADES 
(Página deixada propositadamente em branco) 
1. 1. A família de Alcibíades parece remontar, nas suas origens, a Eurísaces, filho de Ájax. Era um Alcmeónida, pelo lado materno, uma vez que nasceu de Dinómaca, filha de Mégacles $^{1}$. Seu pai, Clínias, combateu gloriosamente na batalha de Artemísio ${ }^{2}$ com uma trirreme equipada a expensas próprias, e veio a morrer mais tarde, em Coroneia ${ }^{3}$, pelejando contra os Beócios. 2. Por isso, Péricles e Arífron, filhos de Xantipo, ficaram como tutores do jovem, por serem os seus parentes mais próximos.

3. Diz-se - e não sem razão - que a estima e simpatia que Sócrates lhe consagrava contribuíram, em não pequeno grau, para a fama que granjeou. É um facto que de Nícias, Demóstenes, Lâmaco, Fórmion, Trasibulo e Terâmenes, que foram homens ilustres e seus contemporâneos, não se sabe sequer o nome da mãe de um só deles, enquanto que de Alcibíades conhecemos até o nome da ama, uma mulher espartana chamada

1 Dinómaca era sobrinha-neta de Clístenes. Seu pai, Mégacles, foi votado ao ostracismo nos anos de 487-486 a. C. Sobre a expressividade das etimologias dos nomes dos progenitores de Alcibíades, vide Pérez Jiménez (2006) 129, n.2.

${ }^{2}$ A batalha deu-se em 480 a. C. Náo é certo que Clínias seja, como afirma Plutarco, o pai, pois este teria, à altura, cinco anos de idade, mas sim um tio-avô deste.

${ }^{3} \mathrm{O}$ recontro de Coroneia teve lugar em 447 a. C.. O exército ateniense foi vencido e o seu general, Tólmides, morto. 
Amicla, e do preceptor, Zópiro. A referência à primeira é feita por Antístenes, ao segundo por Platãó .

4. Em relação à sua beleza, talvez nada seja preciso dizer, excepto que floresceu em cada fase da sua existência: ao longo da infância, da juventude, da sua vida de homem feito, conferindo-lhe um aspecto encantador e agradável. 5. É um facto que a observação de Eurípides, de que em todos os homens belos até no Outono da sua vida a beleza se mantém, nem sempre é verdadeira ${ }^{5}$. No caso de Alcibíades, porém, como em outros raros casos, a afirmação é válida devido aos seus dotes naturais e à perfeição do seu corpo. 6. Diz-se que o seu defeito de pronúncia conferia força de persuasáo ao seu discurso e acrescentava-lhe encanto. 7. O próprio Aristófanes ${ }^{6}$ lembra esse defeito naqueles versos em que pôe a ridículo Teoro:

Então Alcibiades dirigiu-se a mim naquele seu jeito de pronúncia:

- Olha pala Teolo! Tem cabeģa de colvo!

- Eneste caso Alcibiades, falou com acerto, ao confundir o 'r' com o '?'

8. Também Arcipo $^{7}$ faz troça do filho de Alcibíades nestes termos:

${ }^{4}$ Platão, Alcibiades $122 \mathrm{~b}$.

${ }^{5}$ Cf. Plutarco, Moralia 177a e 770c.

${ }^{6}$ V. 44-46. É impossível, na tradução, manter o efeito de ambiguidade e jogo de sentidos do original grego: é que korax ("corvo"), ao ser pronunciado como kolax, torna-se homónimo de "adulador".

${ }^{7}$ PCG frg. 48. Arcipo foi um comediógrafo contemporâneo de Aristófanes. 
Caminha com afectação, arrastando as longas vestes, de modo a parecer o retrato do pai, e inclina a cabeça com afectação $e$ não pronuncia os ' $r$ '.

2. 1. O seu carácter, numa fase posterior da sua vida, manifestou-se inconsequente e instável, como é natural, dadas as grandes empresas em que esteve envolvido e as vicissitudes da sorte que o atingiu. Era, por natureza própria, um homem dado a muitas e violentas paixóes, das quais a mais forte era a ambição e a ânsia de preponderar, como se torna evidente nos episódios que se recordam da sua infância.

2. Certa vez, em que estava em apuros numa luta, para não cair, aproximou em direcção à sua boca os braços do adversário que o dominava, e quase lhos trincava de um lado ao outro. 3. Este, largando a presa, disse-lhe: "Tu mordes, ó Alcibíades, tal e qual como as mulheres!" - ao que Alcibíades respondeu: "Não, tal e qual como os leóes!"8

A dada altura, quando ainda era pequeno, estava a jogar aos dados numa rua estreita e, precisamente quando tinha chegado a sua vez de os lançar, aproximou-se um carro com uma enorme carga. 4. Começou por ordenar ao carroceiro que parasse, pois os dados tinham caído no trilho por onde o carro ia passar. Este porém, que

${ }^{8}$ Sobre o Leitmotiv do leão, utilizado por Plutarco em relação a Alcibíades como modo de sugerir a relação deste com o poder, bem como sobre a ambiguidade sexual da comparação ao comportamento das mulheres, neste episódio, vide Pérez Jiménez (2006) 132, n.13 e o estudo aí citado de Duff (2005) 159. Dou razão a Pérez JimÉnEZ ao entender "que esa ambigüedad es recurrente en toda la Vida". 
era um homem rude, não lhe deu ouvidos e continuou a avançar. Os restantes garotos fugiram, mas Alcibíades lançou-se ao chão, de cabeça, diante do carro, e deitou-se à sua frente, instigando o homem a avançar, se assim o queria, a ponto de este, apavorado, ter estacado à força os animais. As pessoas que presenciaram este episódio correram, em pânico e aos gritos, para ajudar o rapazinho.

5. Quando chegou à altura de começar os seus estudos, escutava de bom grado as liçóes dos seus mestres, mas recusava-se a tocar flauta', por considerar que esta era uma actividade vil e indigna de homens livres. $\mathrm{O}$ uso do plectro e da lira, segundo ele, em nada prejudicavam a figura e o aspecto que convêm a um homem livre, mas quando um homem aplica a sua boca a soprar numa flauta, até os seus familiares têm dificuldade em reconhecer o seu rosto. 6. Em contrapartida, quem dedilha uma lira pode, ao mesmo tempo, falar ou cantar, mas a flauta, na medida em que ocupa e tapa a boca, priva o músico da voz e da palavra. "Que toquem flauta" dizia "os filhos dos Tebanos", já que não sabem conversar. Porém nós, os Atenienses, consoante o dizem nossos pais, temos Atena como deusa fundadora e Apolo como criador da nossa raça. A primeira deitou fora a flauta, o segundo esfolou o flautista. 7. Com estes argumentos,

9 Traduzo por "flauta" o grego aulos. Segundo a tradição foi Atena quem inventou a flauta mas, ao ver, espelhado na água, o seu rosto deformado pelo esforço do sopro, deitou o instrumento fora. O sátiro Mársias tê-lo-ia apanhado, aprendido a tocá-lo e, num gesto de fanfarronice, desafiado Apolo para um certame. Apolo venceu, tocando a sua lira. Como punição pelo seu arrojo, o deus esfolou vivo Mársias. Vide RE s. u. "Marsyas". 
meio a brincar meio a sério, Alcibíades abandonou este instrumento e levou a que outros jovens o fizessem ${ }^{10}$. É que depressa se espalhou entre os da sua idade a ideia de que Alcibíades tinha razáo quando repudiava a flauta e troçava dos que aprendiam a tocá-la.

3. 1. Nas Invectivas de Antifonte ${ }^{11}$ conta-se que Alcibíades, ainda menino, fugiu de sua casa para ir ter com Demócrates, um dos seus amantes, e que Arífron queria procurá-lo mediante uma proclamação pública, mas que Péricles o não permitiu, alegando as seguintes razões: "Se ele está morto, com a proclamação só o saberemos um dia mais tarde; se está a salvo, será como se o não estivesse para o resto dos seus dias". Conta ainda Antifonte que ele matou, com um golpe de bastão, um dos seus servidores na palestra de Sibírtio. 2. Todavia, não há provavelmente motivo para dar crédito a estas acusaçóes, formuladas por alguém que reconhecia ter escrito invectivas contra ele, motivado pelo ódio que por ele alimentava.

4. 1. Já eram muitos os homens de nobre estirpe que se juntavam à volta de Alcibíades e o cumulavam de atençôes. Era evidente que todos eles se sentiam rendidos e prestavam honras ao esplendor da sua juventude; porém, só o amor que Sócrates lhe devotava valia como um importante testemunho do mérito e das qualidades

${ }^{10}$ Sobre a tradição da aversão de Alcibíades à flauta, vide Platão, Alcibiades 106e.

${ }^{11}$ Não é certo, todavia, que se trate de Antifonte, o Orador, autor das Tetralogias, ou do seu homónimo, o Sofista. 
inatas do jovem, cujo brilho ele via transparecer através do seu aspecto físico ${ }^{12}$. No entanto, como Sócrates receava os possíveis efeitos da sua riqueza, da sua posição social, da multidão de cidadáos, de estrangeiros e de aliados que procurava antecipar-se a conquistá-lo com adulaçóes e favores, tratou de o proteger e de não permitir que uma planta desta natureza se estragasse em flor e perdesse o fruto que lhe correspondia dar. 2 . É que não há outro homem a quem a fortuna tenha envolvido e rodeado de um tal conspecto de atributos, para o tornar invulnerável à filosofia e insensível à sua linguagem franca e mordaz. No entanto, Alcibíades, embora pervertido desde o início e impedido pelo círculo dos que o adulavam de prestar ouvidos a quem estava pronto a aconselhá-lo e a instrui-lo, graças aos seus dons inatos reconheceu o valor de Sócrates e admitiu-o na sua companhia. Assim afastou o séquito dos seus amantes ricos e famosos. 3. Depressa fez deste o seu companheiro habitual e escutava os ensinamentos de um amante que não andava em busca de prazeres indignos de um homem, nem reclamava beijos ou carícias - pelo contrário, apontava-lhe os podres da sua alma e reprimia a futilidade e insensatez do seu orgulho. Então Alcibíades ${ }^{13}$ "agachava-se e baixava as suas asas, como um galo vencido".

4. Chegou a pensar que a obra de Sócrates constituía, de facto, uma missão de que os deuses o haviam

${ }^{12}$ A relação entre Sócrates e Alcibíades está, de algum modo, retratada nos diálogos platónicos Alcibiades e Banquete - e assim a tomou a tradição que se atesta em Plutarco.

${ }^{13} \mathrm{O}$ verso é da autoria de Frínico (frg. $17 \mathrm{Nauck}^{2}$ ). 
incumbido, de vigilância e salvaguarda da juventude. Assim, cultivando o desprezo por si mesmo e a admiração por aquele, cuja bondade estimava e cuja virtude the merecia respeito, foi adquirindo, sem dar conta, uma imagem do amor, um "reflexo do amor", como diz Platáo $^{14}$, a ponto de toda a gente se admirar ao vê-lo cear com Sócrates, lutar com Sócrates e albergar-se na mesma tenda com ele. Em contrapartida, era ríspido e intratável com os seus outros amantes e chegava a comportar-se em relação a alguns deles com uma extrema arrogância, como em relação a Ânito, filho de Antémion ${ }^{15}$.

5. Ora acontecia que este homem, Ânito, estava tomado de amores por Alcibíades e, numa ocasião em que recebia uns hóspedes seus, convidou também Alcibíades para a ceia. Este declinou o convite mas, depois de se entregar ao vinho em sua própria casa, veio com os seus companheiros, em cortejo de ébrios, até à casa de Ânito. Parou à entrada da sala de jantar e, ao ver as mesas repletas de taças de prata e de ouro, deu ordens aos seus escravos para recolherem metade das taças e as levarem para sua casa. Ele, por sua vez, nem se dignou entrar e foi-se embora, depois desta proeza. 6. Os convivas, indignados, protestavam perante a insolência e a arrogância com que Alcibíades havia tratado Ânito, ao que este retorquiu: "dizei antes que agiu com cordura e bondade, pois poderia ter levado tudo consigo e deixou-nos uma parte"16.

${ }^{14}$ Platão, Fedro 255d. Esta especularidade de eros vem já a ser desenvolvida desde 255c.

15 Ânito, como se sabe, viria a ser um dos principais acusadores no processo que conduziria Sócrates à morte.

${ }^{16}$ Este episódio é referido em Moralia 762 e Ateneu 534e-f. 
5. 1. Alcibíades tratava todos os seus outros apaixonados com similar arrogância, excepção aberta para um só homem, ao que se diz: um meteco que não tinha muito de seu, mas que vendeu tudo e levou o dinheiro que apurou - ao todo cem estateres ${ }^{17}-\mathrm{a}$ Alcibíades, rogando-lhe que os aceitasse. Alcibíades largou a rir e, divertido, convidou-o para cear. 2. Depois de o ter acolhido à sua mesa e lhe ter concedido provas de amizade, devolveu-lhe o dinheiro e ordenou-lhe que, no dia seguinte, entrasse na licitação e mantivesse a proposta mais alta para adquirir o direito a cobrar impostos públicos. 3. O homem tentou esquivar-se, porque o valor da compra ascendia a uma soma grande de talentos. Contudo, Alcibíades ameaçou mandá-lo açoitar, caso se recusasse. É que tinha motivos pessoais contra os cobradores. 4. No dia seguinte, de manhã cedo, o meteco dirigiu-se à ágora e fez uma licitação de um talento ${ }^{18}$. Então, os cobradores juntaram-se, furiosos contra ele, e intimaram-no a indicar o seu fiador, persuadidos de que náo encontraria nenhum. Mas no momento em que o homem se retirava, perturbado, Alcibíades, que se encontrava presente, gritou de longe aos magistrados: "Registai o meu nome. Sou amigo dele, fico por seu fiador." 5. Ao ouvirem estas palavras, todos os cobradores ficaram desorientados. É que tinham por hábito sistemático pagar o contrato anterior com os proventos do seguinte e não viam como sair da

${ }^{17}$ Esta quantia correspondia a duzentas dracmas.

${ }^{18} \mathrm{O}$ talento tinha o valor de seis mil dracmas. 
dificuldade em que ficaram. Pediram ao homem que desistisse, mediante a oferta de uma soma de dinheiro. Alcibíades, porém, proibiu-o de aceitar uma quantia inferior a um talento. Os outros deram-lhe então um talento e Alcibíades disse ao meteco que o aceitasse e se retirasse. E foi assim que lhe providenciou lucros.

6. 1. O amor de Sócrates por Alcibíades, embora contasse com muitos e poderosos rivais, dominava, por vezes, Alcibíades. É que os discursos do filósofo tocavam os dons inatos do carácter do jovem e mexiam com o seu coração até às lágrimas. Mas outras vezes, porém, entregava-se aos seus aduladores, que lhe acenavam com prazeres inúmeros, e escapava, entâo, a Sócrates. Este movia-lhe caça, como se de um escravo fugitivo se tratasse - era o único homem que lhe inspirava respeito e temor; pelos demais sentia desprezo. 2. Cleantes ${ }^{19}$ dizia que só dominava o seu amado pelos ouvidos, enquanto este oferecia aos seus rivais muitos outros pontos, em que aquele nunca ousaria tocar, por onde ser dominado. Referia-se ao estômago, aos genitais e à garganta. E Alcibíades era, sem dúvida, facilmente arrastado para os prazeres. 3. Tucídides ${ }^{20}$, ao falar do desregramento físico da sua vida privada, deixa que tal se perceba. 4. No entanto, era antes de mais pela sua ambição e pela sua ânsia de glória que o manipulavam aqueles que o corromperam e o lançaram prematuramente em

${ }^{19}$ Referência ao filósofo estóico Cleantes de Assos (frg. 614 Arnim) que viveu nos sécs. III-II a. C. Chegado a Atenas cerca de 280 a. C., sucedeu a Zenão na Stoa.

${ }^{20}$ Tucídides 6.15.4. 
grandes empresas. Persuadiam-no de que, mal iniciasse a sua carreira política, não só ofuscaria prontamente os outros generais e chefes do povo, como até ultrapassaria o poder e a fama de Péricles entre os Gregos. 5. Assim como o ferro que amolece ao fogo de novo endurece por acção do frio e contrai em si todas as suas partículas, do mesmo modo, sempre que Sócrates recuperava o seu domínio sobre um Alcibíades inchado de sensualidade e vão orgulho, reprimia-o e retraía-o com as suas palavras, até o tornar humilde e modesto, fazendo-lhe ver a importância das qualidades que lhe faltavam e as imperfeiçóes que o mantinham arredado da virtude.

7. 1. Já tinha saído da infância quando, em certa ocasiáo, se acercou de um mestre-escola e lhe pediu um livro de Homero. Tendo este respondido que não possuía nada de Homero, Alcibíades aplicou-lhe uma bofetada e prosseguiu o seu caminho. 2. Um outro disse-lhe que possuía um Homero corrigido por seu próprio punho. "Ai sim?!" - exclamou - "Ensinas os jovens a ler, quando és capaz de corrigir Homero, em vez de os instruíres?".

3. Em certa ocasião, querendo encontrar-se com Péricles, veio até à porta da casa deste. Mas quando o informaram que Péricles estava muito ocupado, pois tratava de encontrar maneira de dar contas aos Atenienses, Alcibíades comentou, à medida que se afastava: "Não seria melhor tentar encontrar maneira de não lhes prestar contas?"

Era ainda um adolescente quando tomou parte na expedição militar contra Potideia. Era companheiro 
de tenda de Sócrates e combatia a seu lado nas refregas. 4. Ora quando teve lugar uma grande batalha, ambos se distinguiram na luta, mas como Alcibíades foi ferido e caiu por terra, Sócrates colocou-se à sua frente, protegendo-o, e, sem sombra de dúvida, salvou-o com as suas armas. 5. O prémio de mérito cabia, com toda a justiça, a Sócrates. No entanto, como os generais mostravam o desejo de distinguir Alcibíades com esta honra, em virtude da sua alta posição, Sócrates, que pretendia estimular no jovem a ambição de praticar acçôes belas, foi o primeiro a testemunhar em seu favor e a solicitar que lhe fosse concedida a coroa e a panóplia.

6. Também na batalha de Délion ${ }^{21}$, quando os Atenienses bateram em retirada, Alcibíades, que se encontrava a cavalo, avistou Sócrates, que se retirava a pé, com um pequeno grupo de infantaria. Em vez de prosseguir adiante, no seu cavalo, Alcibíades foi-o escoltando e protegendo dos inimigos que os perseguiam e provocavam grande número de baixas. Mas este episódio ocorreu em data posterior.

${ }^{21}$ Sobre a participação de Sócrates e Alcibíades na campanha de Potideia (431) e na batalha de Délion (424), veja-se Platão, Banquete 220a-221c. Potideia, antiga cidade da Macedónia, foi fundada em 600 a. C. por Coríntios. Situava-se no istmo que liga a península de Palene à Calcídica. Aderiu à Liga de Delos mas, ao ver aumentado o imposto anual pago à Liga, revoltou-se contra Atenas em 432. Rendeu-se pela fome, após um duro cerco de dois anos montado pelos Atenienses. Esta agressáo ateniense constituiu uma das causas do deflagrar da Guerra do Peloponeso. A batalha de Délion, santuário beócio não longe da Ática, próxima do golfo eubeico, foi travada, no decorrer da Guerra do Peloponeso, entre Beócios, que a venceram, e Atenienses. 
8. 1. A Hiponico, pai de Cálias e homem que gozava de grande reputação e autoridade, graças à sua fortuna e linhagem, aplicou Alcibíades uma bofetada $^{22}$. Não o fez movido pela cólera ou por qualquer desavença, mas por chalaça, na sequência de uma aposta feita com os seus companheiros. 2. Esta insolência tornou-se um escândalo na cidade e suscitou, como era natural, a indignação generalizada. No dia seguinte, manhã cedo, Alcibíades dirigiu-se a casa de Hiponico e, depois de ter batido à porta, foi levado à sua presença. Então, tirou o seu manto e ofereceu-lhe o corpo, incitando-o a que o fustigasse e o punisse. 3. Mas Hiponico perdoou-lhe e ultrapassou o seu ressentimento, e mais tarde veio a dar-lhe em casamento a sua filha Hipáreta. Alguns autores afirmam, no entanto, que não foi Hiponico, mas Cálias, seu filho, quem deu Hipáreta em casamento a Alcibíades, juntamente com um dote de dez talentos, e que Alcibíades, quando esta lhe deu um filho, exigiu outros dez talentos, com o argumento de que tal tinha sido acordado se filhos houvesse ${ }^{23}$. 4. Cálias, temendo congeminaçôes por parte de Alcibíades, apresentou-se à Assembleia do povo a quem deixou os seus bens e a sua casa, no caso de vir a morrer sem deixar descendência.

${ }^{22}$ Hiponico era, no seu tempo, considerado como o homem ais abastado de Atenas.

${ }^{23}$ Comenta Mossé (2002) 19 n. 16 que o montante normal dos dotes, de acordo com informação colhida em processos judiciais, oscilava entre as mil e as oito mil dracmas. Ora, correspondendo um talento a seis mil dracmas, pode avaliar-se o quantitativo desmesurado do dote exigido por Alcibíades. 
Hipáreta era uma mulher discreta e amante do seu marido, mas infeliz no seu casamento por causa dele, que frequentava cortesãs estrangeiras e atenienses. Deixou a sua casa e foi viver para casa de seu irmão. 5 . Como Alcibíades não se preocupava e prosseguia com a sua vida dissoluta, ela teve de apresentar ao arconte o seu pedido de divórcio - e fê-lo, não através de um intermediário, mas em pessoa. Quando se apresentou para o fazer, de acordo com a lei ${ }^{24}$, Alcibíades foi ao seu encontro, agarrou-a e levou-a para sua casa, atravessando a ágora sem que alguém ousasse enfrentá-lo ou tirar-lha. 6. Ela ficou com ele até ao fim da sua vida, que chegou não muito tempo depois, quando Alcibíades navegava rumo a Éfeso. Esta violência não pareceu minimamente nem contrária à lei, nem à humanidade: é que parece que é por este motivo que a mulher que quer abandonar o marido deve comparecer perante o magistrado - para que o marido tenha oportunidade de se reconciliar com ela e conservá-la.

9. 1. Alcibíades tinha um cão de um tamanho e de uma beleza admiráveis, que havia adquirido por setenta minas ${ }^{25}$. Cortou-lhe a cauda, embora ela fosse magnífica. 2. Quando os seus familiares o censuravam e lhe diziam que todos o criticavam e falavam mal dele por causa do cáo, soltou uma gargalhada e disselhes: "É isso mesmo que eu pretendo; quero que os

${ }^{24} \mathrm{O}$ passo denota que estaria, todavia, previsto na lei que a mulher pudesse pedir e obter o divórcio, em circunstâncias determinadas.

${ }^{25}$ Soma correspondente a sete mil dracmas. 
Atenienses falem deste assunto para evitarem dizer pior a meu respeito."

10. 1. A sua primeira intervenção na vida pública, ao que dizem, deu-se por ocasião de uma contribuição voluntária para o Estado - que não tinha sido objecto de deliberação prévia, da sua parte. Ele ia a passar quando deu conta de grande alvoroço dos Atenienses na Assembleia. Indagou qual era o motivo. Quando o informaram de que estava em curso uma contribuição voluntária, dirigiu-se à tribuna e fez a sua oferta. A multidáo aplaudia-o e gritava de alegria, a ponto de Alcibíades se ter esquecido da codorniz que por acaso levava no seu manto. 2. A ave, assustada, fugiu e, então, os Atenienses redobraram a gritaria. Muitos levantaram-se para ajudar a caçá-la, mas foi Antíoco, o piloto, quem conseguiu apanhá-la e dá-la de volta a Alcibíades. $\mathrm{Na}$ sequência deste episódio tornou-se o seu amigo favorito. 3. Tinha abertas diante de si as portas principais de acesso à carreira política, graças à sua linhagem, à sua fortuna, à bravura demonstrada em combate e ao grande número de amigos e parentes, mas por nada tinha ele mais apreço do que por impor a sua autoridade sobre a multidáo a partir do poder de sedução da sua palavra. 4. E quanto ao vigor dos seus dotes oratórios, dele são testemunho os poetas cómicos e o maior dos oradores ${ }^{26} q u e$, no seu discurso Contra Midias, afirma que Alcibíades reunia às demais qualidades a sua espantosa eloquência.

${ }^{26}$ Demóstenes, 21.145. 
Se dermos crédito a Teofrasto ${ }^{27}$ que, pela sua preocupação em investigar e conhecer a história, pode ser posto a par de qualquer filósofo, Alcibíades era, entre todos os homens, o mais capaz de descortinar e perceber o que convinha a cada circunstância; e assim, na medida em que ele procurava não só o que era preciso dizer mas também por que palavras e expressóes era preciso dizê-lo, e nem sempre dispunha destes recursos, hesitava com frequência, fazia pausas a meio do discurso e suspendia a palavra quando lhe fugia a expressão certa, enquanto se recompunha, numa atitude de reflexáo.

11. 1. A casta dos cavalos que criava tornou-o particularmente famoso, tal como o elevado número dos seus carros de corrida. Ninguém mais, cidadão privado ou rei, se apresentou sete vezes às competiçóes de corrida, nos Jogos Olímpicos: só Alcibíades. 2. E a glória de ter alcançado uma vez a vitória, de outra vez o segundo lugar, e também o quarto, segundo a versão de Tucídides ${ }^{28}$, ou o terceiro, de acordo com Eurípides, ultrapassa em esplendor e renome tudo o que se pode ambicionar neste domínio.

3. Eis o que Eurípides ${ }^{29}$ canta na sua ode:

És tu quem eu irei cantar, ó filho de Clínias.

Bela é a vitória. Mais belo ainda o que nenhum outro Heleno

${ }^{27}$ Frg. 134 Wimmer de Teofrasto, o sucessor de Aristóteles no Liceu.

${ }^{28}$ Tucídides 6.16.2. A vitória foi alcançada em 416 a. C.

${ }^{29}$ Trata-se, provavelmente, de um epinício de que restou o frg. 3 Diehl. 
logrou alcançar: nas corridas de carros ser o primeiro, o segundo,

[o terceiro, e duas vezes regressar, sem fadiga, coroado de folhas de oliveira, para ser, na voz do arauto, objecto de proclamação.

12. 1. Sem dúvida que o brilho das suas vitórias foi tornado mais intenso pela emulação que as cidades nutriam a seu respeito. Os Efésios ergueram em sua honra uma tenda magnificamente ornamentada; os habitantes de Quios abasteceram-no de comida para os seus cavalos e ofereceram-lhe um elevado número de vítimas; os Lésbios prodigalizaram-lhe vinho e outras provisóes em abundância, para que recebesse à sua mesa hóspedes em profusão. 2. No entanto, o rumor, fosse ele calúnia ou tivesse fundamento, de uma acção indigna, cometida por ocasião daquela competição vitoriosa, deu azo a comentários ainda mais numerosos. 3. Diz-se que havia em Atenas um certo homem, de nome Diomedes - homem honesto, amigo de Alcibíades -, que alimentava o desejo de arrebatar uma vitória nas competiçóes olímpicas. Inteirado de que os Argivos possuíam um carro público e sabendo que Alcibíades gozava em Argos de grande influência e tinha nessa cidade muitos amigos, convenceu-o a comprar o carro. Ora Alcibíades comprou o carro, mas registou-o como seu e mandou Diomedes passear. Este, indignado, invocou como suas testemunhas homens e deuses. Parece mesmo que o caso foi levado a tribunal e que 
Isócrates escreveu até um discurso Sobre a biga ${ }^{30}$ para o filho de Alcibíades. Nesse discurso o litigante tem o nome de Tísias, não de Diomedes.

13. 1. Quando se lançou na política, ainda que fosse um adolescente, eclipsou a maior parte dos oradores. Teve, contudo, que antagonizar com Féax, filho de Erasístrato, e com Nícias, filho de Nicérato. Este último era um homem já entrado em anos e considerado um excelente general. Féax, em contrapartida, estava, no momento, na fase de aumentar a sua influência, tal como Alcibíades, e provinha, ele também, de antepassados ilustres, mas, quanto a tudo o resto, era inferior a Alcibíades, sobretudo como orador. 2. Passava por ser afável e com capacidade de persuasão em conversas privadas, mais do que por ser um indivíduo capaz de sustentar os confrontos de uma assembleia. Era, como $\operatorname{diz} \hat{E}_{\text {upolis }}{ }^{31}$ :

Um excelente conversador e um orador incapaz.

3. Conserva-se um discurso atribuído a Féax, Contra Alcibiades, em que se afirma, entre outras coisas, que muitos vasos rituais de ouro e prata, pertença da cidade, eram usados por Alcibíades no seu dia-a-dia, como se fossem propriedade sua.

${ }^{30}$ O discurso data, provavelmente, de 396 a. C. Mossé (2002) 24 n. 22: "Vingt ans s'étaient écoulés depuis les événements, et Tisias est sans doute le fils de Diomède, qui aurait repris l'action au nom de son père."

${ }^{31}$ Frg. 95 CAF I 281. 
4. Havia um certo Hipérbolo, do demo de Peritoídas, a quem Tucídides ${ }^{32}$ se refere como sendo um homem perverso, que proporcionou a todos os poetas cómicos, de modo similar, contínuo motivo de troça para explorar em cena. 5. Ele, todavia, mantinha-se impassível perante a sua má reputação e insensível a ela, por desprezo para com essa sua reputação - o que alguns classificavam como audácia e coragem e que não é mais que falta de vergonha e insensatez. Ninguém gostava dele, mas, com frequência, o povo servia-se dele quando queria humilhar e caluniar cidadãos dignos. 6. Pois bem, deixando-se convencer por este homem, o povo ia, então, aplicar o ostracismo, medida pela qual cerceavam sempre a carreira de um cidadáo que se distinguisse dos outros pela seu renome e poder, expulsando-o. E faziam-no mais para mitigar a sua inveja que para sossegar do seu medo. 7. Ora quando se tornou óbvio que o ostracismo recairia sobre um dos três oradores, Alcibíades pôs de acordo as diferentes facçôes e, uma vez concertado com Nícias, levou a que o ostracismo recaísse sobre Hipérbolo. 8. Há quem diga que não foi com Nícias mas com Féax que Alcibíades se concertou e que, agregando a facção de Féax, conseguiu a expulsão de Hipérbolo, que não estaria à espera de tal. 9. É que nunca um homem sem valor e sem reputação fora objecto de tal medida, como diz, de algum modo, Platão o Cómico ${ }^{33}$, ao recordar Hipérbolo:

${ }^{32}$ Tucídides 8.73.3.

${ }^{33}$ Frg. 187 CAF I 654, reproduzido também em Plutarco, Nícias11.5-7. 
Recebeu, sem dúvida, o castigo que a sua conduta merecia, ainda que para as suas falhas fosse um destino imerecido, pois não foi para tais homens que o ostracismo se inventou.

14. 1. A Alcibíades não o incomodava menos que Nícias fosse tão admirado pelos seus inimigos quanto venerado pelos seus concidadãos. Alcibíades era, de facto, próxeno dos Lacedemónios e tinha cuidado daqueles que haviam caído prisioneiros em Pilos ${ }^{34}$. 2 . Mas, como foi sobretudo graças à acção de Nícias que os Lacedemónios conseguiram obter a paz e recuperar os prisioneiros, nutriam por este uma particular afeiçáo. Dizia-se, entre os Gregos, que, se Péricles os havia vinculado à guerra, Nícias dela os tinha libertado. E a maioria chamava a esta paz a "paz de Nícias" 35 . Tudo isto provocava em Alcibíades um descomedido desgosto e a sua inveja levou-o a projectar uma violação do tratado. 3. Então, apercebendo-se de que os Argivos odiavam e invejavam os Espartanos e procuravam separar-se deles, alimentou-lhes, em segredo, a esperança de uma aliança militar com Atenas e, quer através de emissários, quer em

${ }^{34}$ Alusão à batalha travada em 424 a. C. em que o general Demóstenes ocupou a baía de Pilos. Nela foram capturados muitos hoplitas espartanos. Pela proxenia um cidadáo de uma pólis era constituído representante dos interesses de determinados cidadãos estrangeiros nessa pólis, e por eles deveria zelar, tendo como fronteira os interesses da sua própria cidade. Sobre este assunto veja-se Ferreira (2004) 227-239.

${ }^{35}$ Este tratado de paz foi celebrado entre Espartanos e Atenienses em 421 a. C. e rematou uma fase da Guerra do Peloponeso. Segundo os seus termos, foram libertados e entregues a Atenas os prisioneiros de Esfactéria e, em contrapartida, foram libertadas as cidades da Liga de Delos que haviam quebrado laços com a Liga. 
encontros com os chefes do povo, tratou de os encorajar a nada recearem e a não cederem aos Lacedemónios, mas, antes, a voltarem-se para os Atenienses e aguardarem que chegasse o momento em que estes náo hesitassem em quebrar o tratado de paz. 4. Quando os Lacedemónios celebraram uma aliança com os Beócios e entregaram aos Atenienses a fortaleza de Panácton, não incólume, como devia ser, mas em ruínas, Alcibíades, aproveitando a exasperação dos Atenienses, acicatou-os ainda mais. Entretanto atacava Nícias, procurando desacreditá-lo com acusaçóes que não deixavam de ser verosímeis. Apontava-lhe o facto de, ao tempo em que fora estratego, não ter querido tomar como prisioneiros de guerra os inimigos que tinham ficado isolados em Esfactéria e de, quando outros os capturaram, os ter libertado e entregue aos Lacedemónios, para lhes cair em graça. 5. Depois acusava-o de não ter demovido os Lacedemónios, de quem era amigo, de estabelecer uma aliança com os Beócios, outra com os Coríntios, e até de impedir qualquer de entre os Gregos que quisesse tornar-se amigo e aliado dos Atenienses de o fazer, caso isso não fosse do agrado dos Lacedemónios.

6. $\mathrm{Na}$ sequência destes ataques, Nícias encontrava-se numa situação difícil quando quis a sorte que chegassem embaixadores vindos da Lacedemónia, trazendo propostas razoáveis e garantindo que estavam investidos de plenos poderes para concluir qualquer acordo que fosse justo para ambas as partes. 7. O Conselho recebeu-os e o povo devia reunir-se em assembleia no dia seguinte. Alcibíades, apreensivo, 
arranjou maneira de chegar à fala, em privado, com os embaixadores. 8. Logo que se reuniram interpelou-os: "Que pensais vós, ó Espartanos? Como não vos destes conta de que o Conselho trata sempre com moderação e cortesia aqueles a quem recebe em audiência e a Assembleia do povo é sempre arrogante e de grandes ambições?! Se declarardes que vindes com plenos poderes de negociação, destratar-vos-á dando-vos ordens e usará de violência. 9. Vamos, ponde de lado essa disposição ingénua. Se quereis ser tratados com moderação pelos Atenienses e não permitir que vos obriguem ao que for contra vossa vontade, discuti sobre o que vos parece justo, como embaixadores que não dispóem de plenos poderes. E eu irei colaborar convosco, para ser favorável aos Lacedemónios”. 10. Depois destas palavras, concluiu com um juramento e assim os afastou de Nícias. Eles ficaram com uma confiança a toda a prova em Alcibíades, admirando a sua habilidade e inteligência, que não eram próprias de um homem qualquer.

11. No dia seguinte, o povo reuniu em assembleia e os embaixadores apresentaram-se. Então Alcibíades perguntou-lhes, da maneira mais cortês, com que poderes se encontravam ali. Eles responderam que não estavam investidos de plenos poderes. 12. De imediato Alcibíades se atirou a eles com gritos de fúria, como se fosse não o autor, mas a vítima de uma ofensa, apodando-os de gente sem palavra, de mentirosos, que tinham vindo a Atenas para nada mais fazerem e ou dizerem que insânias. $\mathrm{O}$ Conselho ficou indignado, o povo tomado pela ira e Nícias ficou perplexo e desencorajado pela mudança de 
atitude dos embaixadores, pois ignorava a armadilha e engano de que tinham sido vítimas ${ }^{36}$.

15. 1. Os Lacedemónios foram assim mandados embora. Alcibíades foi designado como estratego e conseguiu, de imediato, celebrar alianças entre os Atenienses e os cidadáos de Argos, de Mantineia e da Élide. 2. É um facto que ninguém aprovou a maneira como ele agiu, mas o resultado obtido assumiu grandes proporçóes: dividiu e provocou a agitação em quase todo o Peloponeso; num só dia juntou em redor de Mantineia um grande número de escudos para combater contra as forças dos Lacedemónios e preparou o confronto, com os seus perigos, o mais longe possível de Atenas ${ }^{37}$. Assim, se os Lacedemónios vencessem, a vitória não lhes traria grande vantagem, mas se perdessem a batalha, a Lacedemónia teria dificuldade em sobreviver.

3. Depois da batalha, os Mil ${ }^{38}$ tentaram logo em seguida acabar com a democracia em Argos e submeter a cidade aos Lacedemónios, que se apresentaram ali e puseram fim ao regime democrático. 4. Porém, o povo, pegando de novo em armas, conseguiu sair vencedor. Com a sua presença, Alcibíades consolidou a vitória dos democratas. Convenceu-os então a fazer descer os seus longos muros até ao mar, unindo a cidade ao mar e ligando-a, por completo, ao poderio ateniense. 5 . Mandou vir de Atenas carpinteiros e canteiros e foi tal

${ }^{36}$ Cf. Tucídides 5.45 e Plutarco, Nícias 10.4 .

${ }^{37}$ A batalha de Mantineia foi travada em 418 a. C. Cf. Tucídides 5.66-74.

${ }^{38}$ Os Mil representavam a facção oligárquica da pólis de Argos. 
a dedicação que mostrou que com ela granjeou gratidáo e influência para a sua pessoa e para a sua cidade. 6 . Convenceu igualmente os cidadáos de Patras a ligar a sua cidade ao mar por meio de uma longa muralha. Alguém disse aos cidadãos de Patras: "Os Atenienses vão acabar por vos engolir". "Talvez", retorquiu Alcibíades, "mas pouco a pouco e começando pelos pés, enquanto os Lacedemónios vos engoliriam pela cabeça e de uma só vez". 7. Ele aconselhava, contudo, os Atenienses a conservar os seus vínculos com a terra e a confirmar, por actos, o juramento que se apresentava todos os anos para ser formulado pelos efebos no santuário de Agraulo. 8. É que eles juram tratar o trigo da Ática, a cevada, a vinha, a figueira e a oliveira como fronteiras naturais da Ática e considerar como pertença sua a terra cultivada e fértil.

16. 1. Com a inteligência e a habilidade demonstrada nesta sua actividade política e oratória contrastavam a enorme dissolução dos seus costumes, os seus excessos na bebida, os seus desvarios eróticos. Exibia, como se fosse uma mulher, vestes cor de púrpura, que arrastava pela ágora, num luxo insolente. Mandava fazer incisóes nas cobertas das trirremes para aí dormir com mais conforto, pondo o seu leito sobre faixas de tela, retesadas, em vez de o pôr sobre tábuas. Mandou fazer um escudo dourado, destituído de qualquer emblema tradicional - em vez disso ostentava um Amor portador do raio. 2. Os homens mais notáveis, para além de se escandalizarem e de sentirem indignação perante tais extravagâncias, temiam a sua 
indiferença e desrespeito para com as leis, como um indício de propensão para a tirania e excentricidade. Quanto aos sentimentos que o povo nutria a seu respeito, Aristófanes ${ }^{39}$ não os expressou nada mal quando disse:

\section{Ama-o, detesta-o e todavia quer mantê-lo.}

Aristófanes ${ }^{40}$ é ainda mais contundente na seguinte alusão:

Antes de mais, não criar um leão na cidade;

Mas se se cria um, há que aceitar os seus costumes.

4. De facto, os seus donativos ao Estado, as suas coregias $^{41}$, as suas prodigalidades sem igual para com a cidade, o renome dos seus antepassados, o poder da sua palavra, a beleza e o vigor do seu corpo, juntamente com a sua experiência bélica e a sua bravura, faziam com que os Atenienses reagissem a tudo o mais com indulgência e tolerância, dando, por sistema, aos seus excessos as designaçóes mais suaves, como "criancices" e "desejo de se fazer notar". 5. Assim foi quando Alcibíades sequestrou o pintor Agatarco, até que este the tivesse decorado a casa; depois disso pagou-lhe e deixou-o ir embora. Assim foi também quando esbofeteou Táureas, que era corego ao mesmo tempo

${ }^{39}$ Räs 1425 .

${ }^{40}$ Rãs 1431-1432.

${ }^{41}$ A coregia constituía um cargo atribuído aos cidadãos mais ricos, pelo qual ficavam com a responsabilidade de suportar as despesas decorrentes da contratação de um Coro, no contexto de festividades religiosas da pólis. 
que ele e com ele disputava notoriedade da vitória; assim foi quando tomou para si uma mulher, de entre os cativos de Melos, fez dela sua amante e educou o filho que dela teve. 6. Eis aqui um exemplo do que diziam constituir os seus sentimentos humanitários - e, no entanto, ele foi o grande responsável pela matança dos Mélios que tinham atingido a idade de pegar em armas, pois pronunciou-se a favor da aprovação do decreto ${ }^{42}$. 7. Quando Aristofonte pintou Nemeia com Alcibíades sentado entre os seus braços ${ }^{43}$, toda a gente acorreu para contemplar o quadro, que teve grande sucesso. Todavia, os anciāos atenienses ficaram indignados com tudo isto, pois viam aí sinais de tirania e de desprezo pelas leis. 8 . $\mathrm{E}$ até parecia que Arquéstrato não falava a despropósito, quando afirmava que a Hélade náo teria podido suportar dois Alcibíades.

9. Certa vez Tímon, o Misantropo, avistou Alcibíades que saía da Assembleia, depois de um dia cheio de sucesso, rodeado de luzida companhia. Em vez de seguir o seu caminho ou de o evitar, como costumava fazer com relação a toda a gente, Tímon foi ao seu encontro, saudou-o e disse-lhe: "Fazes bem em te

42 A pequena ilha de Melos, antiga colónia Lacedemónia, juntamente com Tera, eram as únicas ilha Cíclades que mantiveram neutralidade na Guerra do Peloponeso. Uma expedição ateniense foi enviada para atacar a ilha de Melos, em 416 a. C., precisamente por esta se recusar a aderir à Liga de Delos. Depois de um cerco de um ano a ilha foi conquistada e arrasada, os homens em idade de pegar em armas foram executados e as mulheres e crianças reduzidos à escravatura. Cfr. Ps.-Andócides 4..22-23: apud PÉrez JimÉnEZ (2006) 151, n.67.

43 Personificação feminina da Nemeia geográfica, concebida para enaltecer Alcibíades. Vide Pérez Jiménez (2006) 151 n. 68. 
tornares grande, filho, pois a tua grandeza será a ruína de todos estes". Uns riram-se, outros insultaram-no, mas outros houve a quem estas palavras causaram profunda impressão. Era assim que as opinióes sobre Alcibíades divergiam, devido aos contrastes da sua natureza.

17. 1. Já em vida de Péricles os Atenienses tinham os olhos postos na Sicília. Após a sua morte, deitaram máos à empresa. De cada vez que uma comunidade da Sicília era maltratada pelos Siracusanos, enviavam-lhe aquilo que designavam como "auxílio" e "apoio militar". Assim estabeleciam pontes para uma empresa militar de maiores proporçóes. 2. Mas quem, de modo decisivo, lhes fez deflagrar o desejo e os persuadiu a conquistar a ilha, não por partes, progressivamente, mas toda, de uma só vez, fazendo-se ao mar com uma grande armada, foi Alcibíades. Ele incutiu no povo grandes expectativas e alimentava, em relação a si mesmo, ambiçóes mais altas. Considerava a expedição à Sicília como um começo de realização das suas aspiraçóes e não, como era opinião corrente, como um fim em si. 3. Nícias, em contrapartida, tendo consciência de que a tomada de Siracusa constituía uma empresa árdua, tentou demover o povo; mas Alcibíades, que sonhava com Cartago e com a Líbia, e que se via já, uma vez levadas a cabo estas conquistas, capaz de dominar a Itália e o Peloponeso, encarava a Sicília como uma mera fonte de provisóes para a guerra ${ }^{44}$. 4. Até os jovens, empolgados por estas esperanças, eram já seus partidários incondicionais

${ }^{44}$ Cf. Tucídides 6.90.23. 
e escutavam com atenção os mais velhos, que lhes relatavam muitas maravilhas sobre a expedição a ponto de muitos Atenienses, sentados nas palestras e em hemiciclos, desenharem o contorno da ilha e a posição relativa da Líbia e de Cartago ${ }^{45}$.

5. Diz-se, no entanto, que Sócrates, o Filósofo, e Méton, o Astrónomo ${ }^{46}$, não esperavam nada de bom para a cidade daquela expedição. $O$ primeiro, ao que parece, por ter sido advertido pelo génio que sempre o acompanhava ${ }^{47}$; quanto a Méton, fosse porque o receio do que estava para acontecer lhe viesse da razáo, fosse por lhe vir de uma espécie de força divinatória, fingiu ter enlouquecido e, deitando mão a uma tocha acesa, simulou que ia deitar fogo à sua casa. 6. Alguns autores afirmam que a loucura de Méton não foi simulação e que ele incendiou a sua casa de noite mas que, ao romper a manhá, se apresentou diante do povo e pediu e suplicou que, tendo em conta tamanha desgraça, o seu filho fosse dispensado de participar na expedição. De qualquer modo obteve o que pedia, conseguindo enganar os cidadãos.

18. 1. Contra sua própria vontade, Nícias foi eleito estratego - cargo a que tentou esquivar-se, sobretudo tendo em conta o seu colega. É que aos Atenienses

45 Trata-se de uma alusão de Plutarco ao debate que animou Atenas antes da decisão tomada, em 415 a. C., de organizar a expedição, sob pretexto de ir em auxílio de Egesto. Cfr. Mossé (2002) 41 n. 37.

${ }^{46}$ Sobre esta figura, veja-se PÉREz Jiménez (2006)153 n. 73.

${ }^{47}$ Daimon. Sobre a tradição de Sócrates daimonios, recebida por Plutarco, vide Hershbell (1988) 374 sqq. 
afigurava-se que o decurso da expedição correria melhor se não fizessem de Alcibíades chefe absoluto, mas antes combinassem a ousadia deste com a prudência de Nícias. 2. E depois, também o terceiro estratego, Lâmaco, embora entrado em anos, não parecia ser menos impetuoso que Alcibíades, nem menos temerário nos combates. Uma vez que se estava ainda na fase de deliberar sobre a quantidade e o modo dos preparativos, Nícias tentou, uma vez mais, intervir para impedir a guerra. 3. Alcibíades, porém, ripostou-lhe e prevaleceu. Então um dos oradores, Demóstrato, apresentou uma proposta e disse que os estrategos deviam ter plenos poderes, quer para os preparativos, quer para toda a conduçáo da guerra.

4. Quando o povo acabou de votar este decreto e tudo estava preparado para a partida, foram vistos maus presságios, inclusivamente na festa que então se celebrava. 5. Aquela ocasiáo coincidiu com a festa de Adónis - festa em que as mulheres expunham por toda a parte imagens que representavam cadáveres prontos para ser enterrados e em que imitavam os ritos funerários, batendo no peito e entoando cânticos fúnebres. 6. Entretanto ocorreu a mutilação dos Hermes $^{48}$. A cabeça da maior parte deles foi danificada numa só noite, o que perturbou muitas pessoas, incluindo aquelas que não atribuíam importância a tais

${ }^{48}$ Cfr. Tucídides 6.27.1. Crespo (1999) 381 n. 42: "Los hermes eran pilares cuadrangulares de piedra tallada en los que estaban figurados la cabeza y los órganos genitales del dios Hermes, como protector de los caminos, de las calles, de las puertas. Estaban situados a las puertas de las casas particulares, de los templos y en el ágora”. 
coisas. 7. Correu a voz de que os autores tinham sido os Coríntios, uma vez que Siracusa era uma colónia coríntia, na esperança de que este presságio travasse os Atenienses ou os fizesse mudar de ideias. 8. Mas a multidão não se deixou levar por esta explicação, nem pela dos que pensavam que se náo tratava de presságios assustadores, mas do efeito normal da embriaguez de jovens libertinos que se deixaram levar até esta brincadeira sacrílega. A multidão considerava o sucedido com fúria e medo, pois via nele o indício de uma conspiração audaciosa que tinha por detrás objectivos bem mais amplos. Tudo o que podia ser alvo de suspeitas foi implacavelmente investigado. Por causa deste episódio, o Conselho e a Assembleia reuniram várias vezes em poucos dias.

19. 1. Entretanto o orador Ândrocles apresentou como testemunhas uns escravos e uns metecos que acusaram Alcibíades e os seus amigos de terem mutilado outras estátuas e de terem parodiado os Mistérios debaixo do efeito do excesso de bebida. 2. Diziam que um tal Teodoro tinha feito de arauto, Pulítion de portador da tocha, Alcibíades de hierofante e que os outros elementos do grupo assistiram como espectadores, no papel de iniciados nos Mistérios. 3. Este é o relato contido no texto da denúncia apresentada por Téssalo, filho de Címon, que acusava Alcibíades de impiedade em relação às duas deusas ${ }^{49}$. O povo mostrava-se revoltado e com

${ }^{49}$ Deméter e Perséfone, mãe e filha, em honra de quem os Mistérios de Elêusis eram celebrados. Teria sido Deméter a fundá-los, para celebrar o regresso periódico de sua filha do Hades à luz do 
dureza de intenções em relação a Alcibíades; e uma vez que Ândrocles, um dos maiores inimigos de Alcibíades, o atiçava contra ele, os partidários de Alcibíades ficaram, de início, perturbados. 4. Este, ao perceber que todos os marinheiros e soldados que se preparavam para se fazer ao mar rumo à Sicília estavam do seu lado, e ao inteirar-se de que os hoplitas de Argos e de Mantineia, mil ao todo, declaravam abertamente que era por causa de Alcibíades que participavam nesta magna expedição militar do outro lado do mar, mas que se alguém o destratasse desertariam imediatamente, ele e os seus recuperaram a confiança e aproveitaram a oportunidade para se justificar. Assim, os seus inimigos ficaram, por seu turno, desencorajados e receosos de que o povo, no julgamento, fosse mais condescendente com ele porque dele precisava. 5. Perante isto, congeminaram fazer com que tomassem a palavra oradores que náo passavam por ser inimigos de Alcibíades, mas que, na verdade, lhe devotavam um ódio não menor que o dos seus inimigos confessos. Eles levantar-se-iam na Assembleia para dizer que não tinha cabimento, naquela ocasião, quando se acabara de pôr um estratego à frente de forças de tal

dia. Como todo o culto iniciático, os Mistérios estavam rodeados de sigilo e o seu conhecimento apenas era acessível aos iniciados, que não deveriam divulgar o que ocorria nas cerimónias de culto. Daí a maior gravidade da paródia do ritual. Os três intervenientes principais na cerimónia eram o hierofante (lit. "o que mostra as coisas sagradas"), encarregado de presidir às cerimónias e revelar aos iniciados os mistérios; o arauto e o portador da tocha, à imagem da deusa Deméter, que procurou sua filha, munida de uma tocha, com a qual é representada. Apenas aos varôes da família dos Eumólpidas estava, por tradição, atribuída a incumbência de desempenharem a função de hierofante. Vide BurKert (1987) 35 sqq. 
dimensão, investido de poder absoluto, com o exército e os aliados a postos, desperdiçar o momento oportuno com sorteios de juízes e mediçóes de água nas clepsidras. 6. "Pois decerto", argumentavam eles, "que Alcibíades embarque já, em boa hora, e, uma vez acabada a guerra, compareça então para apresentar a sua defesa nas mesmas condiçóes.”. 7. A perfídia deste adiamento não escapou a Alcibíades. Subiu então à tribuna e expôs ao povo até que ponto era terrível a sua situação: ser enviado à frente de um exército, enquanto deixava atrás de si um rasto de acusaçôes e calúnias. Devia sofrer a morte, caso náo as refutasse; mas, se as refutasse e provasse a sua inocência, deixassem-no ir ao encontro dos inimigos sem qualquer temor dos caluniadores.

20. 1. Não conseguiu, contudo, persuadir o povo e recebeu ordem para levantar ferro. Assim, embarcou com os outros estrategos. Levava pouco menos de cento e quarenta trirremes, cinco mil e cem hoplitas, cerca de mil e trezentos arqueiros, homens armados de funda, soldados de infantaria ligeira e material bélico considerável $^{50}$. 2. Mal aportou a Itália tomou Régio ${ }^{51}$ e propôs o plano de operaçóes que se devia seguir. 3 . Ainda que Nícias se opusesse, com a adesão de Lâmaco tomou o rumo para a Sicília e anexou Catana. Mas não foi mais além nos seus planos, pois os Atenienses mandaram-no regressar para ser julgado.

${ }^{50}$ Os números coincidem, por arrredondamento, com os que nos dá Tucídides 6.43 .

${ }^{51}$ Neste ponto Plutarco não segue Tucídides 6.44.3, que refere a neutralidade de Régio. 
4. De início, como já tinha referido, só recaíam sobre Alcibíades umas suspeitas e acusaçóes vagas, com origem em escravos e metecos. 5. Mais tarde, porém, aproveitando a sua ausência, os seus inimigos montaram contra ele um violento ataque e, associando as mutilaçóes dos Hermes à profanação dos Mistérios, mantinham que estes dois crimes foram obra de uma só conspiração revolucionária. Foram, assim, metendo na prisão, sem julgamento prévio, quem se tornou alvo de acusação de qualquer tipo de cumplicidade e arrependiam-se de não ter feito com que Alcibíades tivesse sido objecto de votação em assembleia e de o náo haver julgado por actos de tal gravidade. 6. Todos os seus parentes, amigos, familiares, que se expuseram à cólera contra ele foram tratados com a maior dureza. Tucídides omitiu os nomes dos denunciantes, mas outros autores citam Dioclides e Teucro, tal como o faz o poeta cómico Frínico neste passo ${ }^{52}$ :

7. -Tem cuidado, meu caro Hermes, não vás cair e magoar-te, de modo a servires de pretexto para levantar calúnias a um outro Dioclides que te queira fazer mal.

- Sim vou ter cuidado; nem quero ver Teucro recompensado por ser um delator, esse patife estrangeiro.

8. De facto, os denunciantes não apresentaram qualquer prova segura e consistente. Um deles, ao qual perguntavam como tinha reconhecido os rostos dos Hermocópidas, respondeu que tinha sido graças ao

${ }^{52}$ Frg. 58 CAF I 385. 
luar - o que era completamente falso, pois o crime foi praticado em noite de lua nova. Esta mentira provocou os protestos das pessoas sensatas, mas não tornou o povo, ainda assim, mais contemporizador no que diz respeito às calúnias: prosseguiu conforme tinha começado - a meter na prisão, com o mesmo afâ, qualquer um que fosse denunciado.

21. 1. Entre os que estavam a ferros e presos a aguardar julgamento encontrava-se o orador Andócides ${ }^{53}$, cuja ascendência o historiador Helânico ${ }^{54}$ faz remontar a Ulisses. 2. Era tido como um inimigo da democracia e partidário da oligarquia. Mas o que o tornou suspeito de ter mutilado os Hermes foi, sobretudo, o grande Hermes que se encontrava nas imediaçóes de sua casa e que tinha sido oferta da tribo dos Egidas. 3. Este foi, entre o pequeno número de Hermes dignos de nota, praticamente o único que ficou incólume. É por esse motivo que, ainda hoje, é conhecido por Hermes de Andócides, e toda a gente assim o designa, apesar do testemunho da sua inscrição.

4. Ora aconteceu que, entre os que foram presos debaixo da mesma acusação, Andócides travou estreita amizade com um homem chamado Timeu. Não era um notável, como Andócides, mas era dotado de uma inteligência e de uma audácia extraordinárias. 5. Este homem convenceu Andócides a dar-se como culpado a ele e a alguns outros, em número reduzido; é que, por

${ }^{53}$ Andócides deixou, no seu discurso Sobre os Mistérios, um extenso relato sobre estes acontecimentos.

${ }^{54}$ FGrH 4 F 170 b. 
decreto votado pelo povo, era concedida impunidade a quem confessasse os seus delitos, enquanto o resultado do julgamento era incerto para todos eles, e de temer, especialmente para os que fossem poderosos; mais valia salvar a vida com uma mentira que morrer de forma vergonhosa, sob a mesma acusação e, tendo em conta o interesse comum, sacrificar um punhado de homens de reputaçáo duvidosa para salvar da cólera popular um grande número de homens de bem. 6. Foi isto que Timeu disse e conseguiu convencer Andócides. Este deu-lhe ouvidos e confessou-se culpado, ele, e alguns outros. Obteve a impunidade, segundo os termos do decreto. Porém, todos aqueles que tinha mencionado foram executados, excepto os que fugiram. Para se tornar mais convincente, Andócides denunciou até alguns escravos de sua casa.

7. No entanto, o povo não tinha ainda apaziguado a sua cólera. Pelo contrário: uma vez eliminados os Hermocópidas, descarregou toda a cólera que ainda o dominava sobre Alcibíades e, por fim, fez ao mar a trirreme de Salamina para o trazer de volta, não sem que antes tivesse recomendado aos emissários que não recorressem à violência nem lhe pusessem as mãos em cima, mas que o abordassem com palavras muito comedidas, instigando-o a acompanhá-los para poder ser julgado e convencer o povo da sua inocência. 8. É que se temia agitaçóes e motins do exército em terra inimiga, o que Alcibíades facilmente poderia suscitar, caso quisesse ${ }^{55}$,

${ }^{55}$ Nota Pérez JimÉnez (2006) 160 n. 96 que Plutarco resume aqui, praticamente, Tucídides 6.61.1-4. 
pois os soldados sentiam-se desencorajados com a ideia da sua partida. Temiam que, com o comando nas mãos de Nícias, a guerra se arrastasse com sucessivos compassos de espera e períodos de inactividade, a partir do momento em que fosse retirada essa espécie de acicate que espicaçava à acção. 9. De facto, Lâmaco era um homem belicoso e cheio de coragem; faltava-lhe, contudo, prestígio e autoridade, já que era pobre.

22. 1. Como consequência imediata da partida de Alcibíades, Messina escapou às mãos dos Atenienses. Havia, de facto, cidadãos de Messina que se preparavam para entregar a cidade. Alcibíades, que conhecia exactamente as suas identidades, denunciou-os aos partidários dos Siracusanos e deitou o plano a perder. Uma vez aportado a Túrios, desembarcou da trirreme e escondeu-se, escapando assim aos que o buscavam. 2. Alguém que o reconheceu disse-lhe: "Não confias, ó Alcibíades, na tua pátria?" "Quanto a tudo o resto, sim", retorquiu, "mas no que diz respeito à minha vida, nem na minha própria mãe confiaria, não fosse ela, por lapso, depositar o voto negro em vez do branco!". 3. Quando veio a saber, posteriormente, que a cidade o tinha condenado à morte exclamou: "Pois agora vou-lhes mostrar que estou vivo."

4. Da denúncia pública, que ficou registada por escrito, consta o seguinte: "Téssalo, filho de Címon, do demo de Laquíades, acusa Alcibíades, filho de Clínias, do demo de Escambónides, de ter cometido um sacrilégio em relação às duas deusas, ao parodiar 
os seus Mistérios e os revelar aos seus companheiros, em sua própria casa. Envergando vestes similares às que leva o hierofante quando mostra os objectos sagrados, intitulou-se ele mesmo de hierofante, designou Pulítion portador da tocha, Teodoro, do demo de Fegeia, arauto, e chamou aos restantes companheiros mistas e epoptas ${ }^{56}$, em violação dos preceitos e disposições instituídos pelos Eumólpidas, os Cérices ${ }^{57}$ e os sacerdotes de Elêusis."

5. Alcibíades foi condenado à revelia, os seus bens foram confiscados e ficou ainda decidido que seria amaldiçoado por todos os sacerdotes e sacerdotisas. Uma só, segundo se diz - Teano, filha de Ménon, do demo de Agrila -, se recusou a acatar este decreto. Declarou que a sua função de sacerdotisa era rezar, não amaldiçoar.

23. 1. No momento em que foram pronunciadas tais decisões e tão pesada condenação, Alcibíades encontrava-se em Argos; é que, mal escapou de Túrios, dirigiu-se para o Peloponeso. No entanto, como receava os seus inimigos e uma vez que tinha renunciado de todo à sua pátria, mandou intermediários aos Espartanos, solicitando que estes lhe garantissem imunidade e lhe dessem a sua confiança. Assim ele poderia prestar-lhes favores e serviços mais relevantes que os danos que lhes havia causado no tempo em que contra eles combatera. 2. Os Espartanos concordaram e apressaram-se a recebê-lo. Mal chegou, tomou várias iniciativas decisivas: a primeira, ao dar conta da lentidão e do modo como os

${ }^{56}$ Mistas chegados ao mais alto grau iniciático.

${ }^{57}$ Outra das famílias tradicionalmente associadas às cerimónias dos Mistérios. 
Espartanos adiavam o envio de socorros aos Siracusanos, foi abrir-lhes os olhos e incitá-los a enviar Gilipo como comandante e que desmantelassem, assim, o poderio que os Atenienses lá possuíam; a segunda foi incitá-los a retomar, na Grécia, a guerra contra os Atenienses; a terceira e mais importante consistiu em fortificar Decelia, empresa que contribuiu, mais do que qualquer outra, para deitar a perder e destruir a cidade ${ }^{58}$.

3. Se ele era famoso e admirado pela sua actuação política, não o era menos pela sua vida privada: seduzia e conquistava o povo ao adoptar os hábitos de vida lacónios. Quantos o avistavam de barba rapada, a tomar banho em água fria, a comer o habitual pão de cevada e o caldo negro, dificilmente acreditavam no que os seus olhos viam e interrogavam-se se aquele homem já tivera algum dia um cozinheiro em sua casa, ou se já teria visto um perfumista ou consentido que o seu corpo envergasse vestes de Mileto. 4. É que ele possuía um dom único, segundo se diz, entre os muitos de que era detentor, e que constituía uma técnica para prender as pessoas: tal consistia em se adaptar aos seus costumes e modos de vida. Era mais rápido no seu mimetismo que o camaleão. 5. Há uma cor, ao que se diz, que o camaleão não é capaz de tomar - a cor branca -, enquanto Alcibíades era capaz de passar com igual facilidade do bem ao mal e do mal ao bem e náo havia comportamento a que ele se não conseguisse adaptar ou que não conseguisse assumir. Em Esparta praticava exercícios físicos, era sóbrio e austero;

${ }^{58}$ Os Espartanos ocuparam a fortificação de Decelia, na fronteira ática, vital para daí enviarem expediçôes de ataque. Mantiveram a sua posse até ao fim da guerra. 
na Iónia era efeminado, voluptuoso e indolente; na Trácia entregava-se à bebida e a montar a cavalo; quando esteve na corte do sátrapa Tissafernes, ultrapassou em pompa e despesismo a magnificência persa. Isto não quer dizer que lhe fosse fácil abandonar um modo de vida para adoptar outro, nem que ele estivesse sempre pronto a mudar, pelo seu próprio carácter, mas antes porque, na medida em que tinha consciência de que, se seguisse a sua própria natureza, iria ter dissabores com aqueles que o cercavam, adoptava então, por sistema, as atitudes e formas adequadas àqueles com quem convivia, e aí encontrava o seu modo de se achar seguro.

6. De qualquer modo, na Lacedemónia, a julgar pelo seu aspecto exterior, poderia dizer-se $\mathrm{s}^{59}$ :

Não, tu não és filho de Aquiles, mas Aquiles em pessoa,

um homem como o educou Licurgo. No entanto, se alguém tivesse podido observar os seus verdadeiros sentimentos e acçóes, poderia comentar ${ }^{60}$ :

\section{É hoje a mesma mulher de antes!}

7. De facto, seduziu Timeia, esposa do rei Ágis, enquanto este se encontrava ausente, numa expedição militar em terra estrangeira. E fê-lo a ponto de esta, ainda que ficasse à espera de um filho de Alcibíades, nem sequer o dissimular. Veio a dar à luz um filho varão a quem, em público, chamava Leotíquidas. No

59 TGF adesp. $363 \mathrm{~N}^{2}$.

${ }^{60}$ Eurípides, Orestes 129. 
entanto, portas adentro de sua casa, o nome por que sua mãe o chamava, em voz baixa, diante de amigas e de servas, era Alcibíades, táo grande era a paixão que a dominava. 8. Ele, por seu turno, dizia, ufano, que, se tinha feito aquilo, não fora para ultrajar o rei, nem por se ter deixado dominar pelo prazer, mas para que os seus descendentes reinassem na Lacedemónia. Muitos foram os que denunciaram a Ágis o que se tinha passado. 9. Mas o que o convenceu decisivamente foi o cálculo de tempo. Por ocasiáo de um tremor de terra ele fugiu, assustado, do leito de sua mulher e nos dez meses seguintes não teve relaçóes com ela. Uma vez que Leotíquidas nasceu depois deste período de tempo, o rei declarou abertamente que o filho não era dele. E foi por este motivo que Leotíquidas foi excluído da linha de sucessão ao trono.

24. 1. Depois do desastre dos Atenienses na Sicília ${ }^{61}$, os cidadãos de Quios, de Lesbos e de Cízico, querendo quebrar a aliança com Atenas, enviaram simultaneamente embaixadores a Esparta. Os Beócios apoiavam os Lésbios e Farnábazo apoiava os de Cízico. No entanto, os Espartanos, seguindo os conselhos de Alcibíades, decidiram ir em auxílio de Quios

${ }^{61}$ Uma vez levantado o cerco a Siracusa, deu-se a retirada do exército ateniense, comandado por Nícias que reconheceu a derrota em 413 a. C. A Pérsia viu, então, a oportunidade de apoiar a facção espartana. A debilidade ateniense deu azo à quebra de apoios por parte de aliados seus. Estes factos e os que se seguem são narrados por Tucídides 8 , de modo muito próximo à narrativa de Plutarco, que o tomou como fonte principal. 
antes de mais. 2. Então, o próprio Alcibíades se fez ao mar e provocou praticamente a revolta de toda a Iónia. Acompanhava frequentemente os estrategos da Lacedemónia e náo parava de causar danos a Atenas. 3. Ágis, porém, que se tinha tornado seu inimigo por causa da afronta que lhe tinha feito com relação a sua mulher, sentia-se vexado pela glória que este atingira, pois dizia-se que quase todas as expediçóes se empreendiam e tinham sucesso graças à intervenção de Alcibíades. Os mais poderosos e ambiciosos de entre os demais Espartanos também já nutriam por ele uma inveja insuportável. 4 . Tiveram a influência suficiente para levar os magistrados de Esparta a incumbir os da Iónia de o matar.

Alcibíades foi informado secretamente e ficou com receio. Continuou, entâo, a participar nas empresas dos Lacedemónios, mas evitava, de todas as maneiras, cair nas mãos deles. De modo a ficar em segurança, colocou-se sob a protecção de Tissafernes, sátrapa do $\operatorname{Re}^{i}{ }^{62}$. A partir desse momento tornou-se a figura mais proeminente e influente da corte daquele. 5. A sua versatilidade e o elevado grau da sua inteligência conquistaram a admiração do Bárbaro, que não era um homem frontal, mas antes de mau carácter e dado a perversidades. Além disso, no convívio e nos prazeres do dia-a-dia a companhia de Alcibíades desprendia tal encanto que ninguém lhe resistia nem conseguia ficar-lhe insensível. Até aqueles que o temiam e por ele nutriam inveja eram tocados pelo prazer e alegria de estar com ele

${ }^{62} \mathrm{O}$ governante de uma das satrapias (províncias) ocidentais do império persa. 
e de o contemplar. 6. Deste modo Tissafernes, que, nas demais circunstâncias, se mostrava um homem cruel e odiava os Gregos mais que qualquer outro Persa, acolhia a adulação de Alcibíades a ponto de lhe retribuir com favores, de modo a compensar largamente essa adulação. 7. Assim, de entre os jardins que possuía, o mais belo, pelos seus prados e pelas suas águas cristalinas, pelos seus recantos e pavilhóes decorados com um luxo digno de um rei e inultrapassável, recebeu, da parte do sátrapa, o nome de Alcibíades, e toda a gente o conhecia por esse nome.

25. 1. Alcibíades, após ter abandonado o lado dos Espartanos, por estes não serem de confiança, temia Ágis. Por tal, falava mal deles e tratava de os denegrir aos ouvidos de Tissafernes. Dissuadiu o sátrapa de lhes prestar generosamente apoio e de provocar a completa ruína dos Atenienses; aconselhou-o a, de preferência, usar de parcimónia no seu contributo e, assim, provocar um enfraquecimento e um desgaste gradual às duas partes, até as deixar nas mãos do Rei, após se terem mutuamente esgotado ${ }^{63}$. 2. Tissafernes facilmente se deixou persuadir por Alcibíades e eram evidentes o afecto e admiraçáo que a este dedicava, de modo que ambas as facçóes gregas nele tinham postos os olhos. Os Atenienses arrependiam-se dos decretos que contra ele haviam promulgado e que se tinham convertido na fonte dos seus dissabores. Alcibíades, por seu turno, já sentia também apreensão e receio, caso Atenas fosse

${ }^{63}$ Cf. Tucídides 8.46.1. 
completamente destruída, de poder vir a cair nas máos dos Lacedemónios, por quem era odiado.

3. Nessa ocasião, as forças dos Atenienses estavam praticamente todas concentradas em Samos. Era dali que partiam com a sua armada, umas vezes para reconquistar aliados que se haviam afastado, outras para lhes dar cobertura. É que ainda se encontravam em condiçóes de fazer frente aos seus inimigos em combate naval. 4. Todavia, temiam Tissafernes e as cento e cinquenta trirremes fenícias, cuja vinda se dizia iminente. Com a sua chegada não restava qualquer esperança de salvação para a cidade. 5. Alcibíades, consciente disto, enviou uma mensagem, em segredo, aos Atenienses com poder em Samos. Incutia-lhes a esperança de lhes conseguir a amizade de Tissafernes, não para conquistar as boas-graças do povo, em quem não confiava, mas para agradar aos aristocratas, caso estes tivessem a coragem de pôr termo à insolência do povo e, por si mesmos, salvar a situação e, com ela, a cidade. 6. Todos os estrategos acolheram sem reservas a mensagem de Alcibíades, à excepção de um deles - Frínico, do demo dos Diradiotas, por nutrir suspeitas, aliás fundamentadas, de que Alcibíades não curava mais da oligarquia que da democracia e de que Alcibíades procurava, a todo o custo, provocar que o chamassem de regresso e de que, por isso mesmo, ele começava por criticar o povo, de modo a agradar aos poderosos e captar as suas simpatia. E, assim, Frínico manifestou-se contra as suas propostas. 7. A sua opiniáo, no entanto, não prevaleceu e, considerado já inimigo público de Alcibíades, enviou em segredo uma mensagem 
a Astíoco, almirante da armada inimiga, na qual the recomendava que tivesse cautela em relação a Alcibíades e o detivesse, já que este fazia jogo duplo. Não se apercebeu, no entanto, que ele mesmo se converteu num traidor em conversaçôes com outro traidor. 8. Com efeito, Astíoco, que sentia pavor de Tissafernes e via a grande influência que Alcibíades exercia sobre o Persa, revelou a ambos a mensagem de Frínico. 9. Alcibíades enviou de imediato a Samos mensageiros para denunciar Frínico. Indignados, todos se uniram contra Frínico que, não encontrando outro meio para sair de apuros, tratou de sanar o mal com um mal maior. 10. Enviou de novo um emissário a Astíoco, censurando-o pela sua delação e anunciando-lhe que lhe entregaria as naus e o acampamento militar dos Atenienses.

11. No entanto, a traição de Frínico não prejudicou os Atenienses, graças à contra-reacção traiçoeira de Astíoco, que, mais uma vez, tudo revelou a Alcibíades. 12. Frínico, porém, que já pressentia isto, como esperava uma segunda acusaçáo da parte de Alcibíades, antecipou-se e anunciou aos Atenienses que os inimigos preparavam um ataque, aconselhando-os a não abandonarem as naus e a fortificarem o acampamento. 13. Enquanto os Atenienses se ocupavam destas tarefas, chegou nova missiva da parte de Alcibíades, na qual este os aconselhava a manter vigia sobre Frínico, pois Frínico tinha intenção de entregar a armada aos inimigos. Os Atenienses não acreditaram, pois pensavam que Alcibíades, uma vez que estava a par dos preparativos e dos planos dos inimigos, abusava para lançar contra 
Frínico acusaçôes infundadas. 14. Todavia, quando mais tarde Hérmon, um dos guardas da fronteira ${ }^{64}$, cravou um punhal em Frínico e o matou em plena ágora, os Atenienses, no julgamento que se seguiu, proferiram post mortem a condenação Frínico, reconhecendo-o culpado de traição, e distinguiram com coroas Hérmon e os seus cúmplices ${ }^{65}$.

26. 1. Mas nesse momento, em Samos, os apaniguados de Alcibíades dominavama situação. Enviam, então, Pisandro à cidade de Atenas, com o objectivo de mudar o regime político e encorajar os poderosos a tomar conta dos assuntos de estado e derrubar a democracia, pois essas eram as condiçóes impostas por Alcibíades para assegurar a amizade e aliança de Tissafernes. Esta foi, com efeito, a justificação pretextada pelos cidadáos que estabeleceram a oligarquia. 2. Mas uma vez que aqueles que se designavam por Cinco Mil - e que, na verdade, eram Quatrocentos ${ }^{66}$ - lograram apoderar-se do poder, deixaram de se preocupar com Alcibíades e encaravam os

${ }^{64} \mathrm{~A}$ tarefa de guarda da fronteira, peripolos, era desempenhada por jovens atenienses durante os anos de efebia.

${ }^{65}$ Vide Pérez JimÉnez (2006) 169 n. 114 sobre as fontes de Plutarco para o relato destes acontecimentos. $\mathrm{O}$ assassinato de Frínico teve lugar em 411 a. C., mas não às mãos de Hérmon. Parece ter sido um Grego, náo de Atenas, Trasibulo, o seu assassino. A este mesmo Trasibulo foi concedida a cidadania em 409 a. C.

${ }^{66}$ A queda da democracia, com a criaçáo do Conselho dos Quatrocentos, ocorreu em 411 a. C. Este regime oligárquico reconhecia apenas a cinco mil cidadáos atenienses (de entre os cerca de trinta mil) o direito de participação na vida política. Todavia, o governo ficava nas mãos de quatrocentos cidadãos que, por iniciativa sua, caso entendessem necessário, convocariam os restantes dos cinco mil (Tucídides 8.67.3). 
empreendimentos bélicos com mais lassitude, em parte por não confiarem nos cidadáos, descontentes com a mudança política, em parte por estarem convencidos de que os Lacedemónios, mais favoráveis a uma oligarquia, se mostrariam mais brandos. Então o povo ateniense manteve-se em acalmia, ainda que contra vontade, mas por medo. É que os Quatrocentos tinham chacinado um bom número de cidadãos que lhes tinham feito oposição abertamente. 3. No entanto, os que estavam em Samos, quando se inteiraram desta situação, ficaram indignados e dispuseram-se logo a embarcar rumo ao Pireu. Depois de chamarem Alcibíades e de o nomearem estratego, pediram-lhe que os capitaneasse para irem pôr fim à tirania.

4. Mas este não agiu então como o teria feito alguém subitamente elevado ao poder pelo favor do povo e que, agradado com isso, pensaria dever agir para logo o satisfazer, sem contrariar aqueles que, de exilado e fugitivo, o acabavam de elevar à condição de estratego e de o pôr à cabeça de uma armada táo poderosa, de um exército e de uma força tal. Antes, comportou-se como um verdadeiro comandante. Soube resistir ao impulso daqueles soldados entáo dominados pela cólera, evitou que eles cometessem algum erro e, assim, preservou nessa ocasião, manifestamente, os interesses da sua cidade. 5 . $\mathrm{Se}$, de facto, tivessem levantado ferro e tomado o rumo da cidade pátria, os inimigos poderiam ter-se apoderado de toda a Iónia, do Helesponto e das ilhas, enquanto os Atenienses lutavam com Atenienses, levando a guerra para dentro da sua própria cidade. Foi única e 
exclusivamente Alcibíades, ou pelo menos ele mais que qualquer um, quem evitou que tal sucedesse; é que não só persuadiu o exército e o fez tomar consciência, como o fez em particular, junto de cada homem, pedindo a uns e forçando outros. 6. Com ele cooperou Trasibulo, do demo da Estíria, que o acompanhava, gritando. É que este homem, segundo se dizia, possuía a voz mais forte de Atenas ${ }^{67}$.

7. Depois desta, uma segunda iniciativa de mérito foi tomada da parte de Alcibíades. Prometeu que traria para o seu lado os navios fenícios, enviados pelo Rei e esperados pelos Lacedemónios, ou que, pelo menos, eles não alcançariam o lado do inimigo. Então, embarcou a toda a pressa. 8. Quando os navios se começaram a avistar, perto de Aspendos, Tissafernes impediu-os de prosseguir, faltando ao prometido aos Lacedemónios. Alcibíades foi acusado por ambas as facçôes, sobretudo pela dos Lacedemónios, de estar na origem da retirada dos navios, tendo aconselhado o Bárbaro a deixar que os Gregos se destruíssem uns aos outros ${ }^{68}$. 9. De facto, náo ficava margem para dúvidas que, se uma força tão grande se juntasse a uma das duas facçóes, iria arrebatar à outra todo o poderio marítimo.

27. 1. Na sequência destes factos os Quatrocentos foram derrubados, graças à entusiástica colaboração entre os amigos de Alcibíades e os partidários da democracia. Os

${ }^{67}$ A Estíria ficava na Fócida. Trasibulo veio a ser o restaurador da democracia, em 403 a. C.

${ }^{68}$ Sobre as possíveis razóes desta atitude de Tissafernes veja-se Tucídides 8.87. 
cidadãos que haviam permanecido em Atenas desejavam Alcibíades de volta e incitavam-no a regressar, mas ele, no entanto, entendia que não devia voltar de mãos vazias e sem nada ter feito, graças à compaixão e ao favor do povo, mas, antes, coberto de glória. 2. Por isso, partiu de Samos com um reduzido número de navios rumo às cercanias de Cnidos e de Cós. Aí, uma vez informado de que o Espartano Míndaro rumava em direcção ao Helesponto, com toda a sua armada, e que os Atenienses o perseguiam, apressou-se a ir levar auxílio aos estrategos. 3. Quis o acaso que ele chegasse, com as suas dezoito trirremes, no preciso momento em que ambas as partes se tinham precipitado para o confronto, com a totalidade dos seus navios, e travavam, nas cercanias de Abidos, uma grande batalha naval que se prolongava até ao anoitecer, com vitórias e reveses sucessivos 4. A aparição de Alcibíades provocou reacçóes contrárias num e noutro lado, de modo que os inimigos se encheram de coragem e os Atenienses foram tomados pela inquietação. Mas logo Alcibíades fez içar uma insígnia de amizade na nau capitã e lançou-se, sem delongas, sobre os Peloponésios que estavam em vantagem e que perseguiam os inimigos. 5. Depois de os ter posto em fuga, empurrou-os contra a costa e atacou-os, investindo contra as suas embarcaçóes e destruindo-as. Enquanto os homens escapavam a nado, Farnábazo acorria em seu auxílio, com o seu exército de terra, e combatia junto à costa, para defender os navios. 6. Ora, no final, os Atenienses capturaram trinta navios inimigos, recuperaram os que tinham perdido e ergueram um troféu ${ }^{69}$.

${ }^{69}$ A partir daqui uma das fontes preferenciais é Xenofonte, 
Após este êxito brilhante, Alcibíades, desejoso de logo ostentar o seu prestígio aos olhos de Tissafernes, preparou presentes de hospitalidade e outras ofertas e dirigiu-se à sua presença, com uma escolta digna de um general. 7. Todavia, o encontro não decorreu consoante as suas expectativas, pois a Tissafernes, de quem os Lacedemónios se queixavam havia já muito tempo e que temia ser castigado pelo Rei, pareceu-lhe que a chegada de Alcibíades vinha a calhar. Deteve-o e fê-lo guardar como prisioneiro em Sardes, na esperança de que esta injustiça o libertasse daquelas acusaçóes ${ }^{70}$.

28. 1. Ao fim de trinta dias Alcibíades arranjou maneira de providenciar um cavalo, escapou aos guardas e fugiu para Clazómenas ${ }^{71}$. 2. E contra Tissafernes pôs a correr o boato de que aquele mesmo o tinha deixado partir, enquanto, por si, se fez ao mar, navegando até ao acampamento militar dos Atenienses. Aí ficou a saber que Míndaro se encontrava em Cízico, juntamente com Tissafernes. Então, tratou de acicatar os soldados, dizendo-lhes que, para eles, se tratava de uma questão de necessidade dar luta ao inimigo por mar, por terra e até, por Zeus!, atacando as muralhas das suas cidades, pois não haveria riquezas para quem náo obtivesse a vitória total. 3. Depois de equipar os navios e de chegar ao

Helénicas. Estes acontecimentos específicos são relatados por Xenofonte, Helénicas 1.1.6. Sobre a mistura de fontes e informações em relação ao troféu vide PéreZ JiMÉNEZ (2006) 173 n.125.

${ }^{70} \mathrm{Cf}$. Xenofonte, Helénicas 1.1.9.

${ }^{71}$ Cidade iónica da Lídia, situada na costa sul do golfo de Esmirna. Aí nasceu Anaxágoras. A cidade fez parte da Liga de Delos. 
Proconeso, deu ordens para que as embarcaçóes ligeiras fossem cercadas pela armada e mantidas sob vigilância desta, de modo a que os inimigos não tivessem, de forma alguma, qualquer indício da sua proximidade. 4 . Quis o acaso que caísse de súbito uma chuvada grossa, acompanhada de trovoada e de nevoeiro. Este jogou a seu favor e permitiu-lhe ocultar as suas manobras. É que não só passou despercebido aos seus inimigos, como, para além disso, conseguiu levantar ferro, depois de dar ordem de embarque aos próprios Atenienses que já tinham desistido de entrar em batalha. 5. Pouco tempo depois a bruma dissipou-se e podiam ver-se os navios dos Peloponésios ancorados diante do porto de Cízico. 6. Temendo que os inimigos, ao avistar um grande número de navios, fugissem para terra ${ }^{72}$, Alcibíades deu, então, ordem aos outros estrategos, companheiros na empresa, para que navegassem lentamente, deixando-se ficar para trás, enquanto ele se fazia ver com quarenta naus e provocava os inimigos para o combate. 7. Como estes caíssem na armadilha e subestimassem os adversários, que julgavam ser em pequeno número, saíram ao seu encontro e avançaram para a batalha. Mas quando os demais navios se juntaram à peleja, os adversários, tomados de pânico, puseram-se em fuga. 8. Alcibíades, reunindo as vinte melhores naus, abriu caminho através da armada inimiga, dirigiu-se à costa e desembarcou. Então, lançando-se sobre os que tentavam fugir dos navios, levou a cabo uma chacina. Venceu Míndaro e Farnábazo, que acorreram a socorrer as tropas. Míndaro

\footnotetext{
${ }^{72}$ Vide Xenofonte, Helénicas 1.1.16-17.
} 
foi morto num aceso combate, enquanto Farnábazo se pôs em fuga. 9. Grande número de cadáveres e de armas ficaram em poder dos Atenienses, a totalidade dos navios inimigos caiu na sua posse e tomaram Cízico, após a fuga de Farnábazo e a morte dos Peloponésios. A partir daí não só ganharam uma posição segura no Helesponto como expulsaram vigorosamente os Peloponésios do resto do mar. 10. Apreenderam até a missiva que, em termos lacónios, comunicava aos éforos o desastre ocorrido: "Perderam-se os navios. Míndaro morreu. Os soldados têm fome. Não sabemos que fazer" ${ }^{\text {”3 }}$.

29. 1. Tão ufanos ficaram os soldados que tinham combatido ao lado de Alcibíades, e de tal modo orgulhosos da sua vitória, que consideravam coisa indigna misturarem-se - eles, os invencíveis - com os outros que haviam sido vencidos muitas vezes. 2 . É que, pouco tempo antes, Trasilo tinha sofrido uma derrota em Éfeso, cujos habitantes ergueram um troféu, para vergonha dos Atenienses. 3. Era, pois, isto que os soldados de Alcibíades, orgulhosos de si e do seu general, apontavam aos de Trasilo; e recusavam-se a participar, com estes, nos treinos físicos, ou a partilhar espaço no acampamento militar. 4. No entanto, quando Farnábazo, à frente de um grande corpo de cavalaria e de infantaria, caiu sobre estes últimos, na sequência de uma incursão que levavam a cabo a Abidos, Alcibíades acudiu em seu auxílio e, ele e Trasilo juntos, puseram

${ }^{73}$ Lembra Pérez Jiménez (2006) 176, n.134 que Xenofonte, Helénicas 1.1.23, diz tratar-se de uma carta enviada pelo filho de Míndaro, Hipócrates. 
em debandada Farnábazo e os seus e perseguiram-nos até ao cair da noite. E foi assim que ambos os esquadróes atenienses se misturaram e regressaram ao acampamento, confraternizando, juntos e satisfeitos. 5 . No dia seguinte, Alcibíades ergueu um troféu e saqueou as terras de Farnábazo sem que alguém ousasse resistir. Aos sacerdotes e sacerdotisas que aprisionou libertou-os, contudo, sem pedir resgate. 6. De seguida, partiu para dar luta aos Calcedónios, que tinham desertado e acolhido uma guarnição e um governador lacedemónio. Mas quando foi informado de que eles tinham reunido tudo o que fosse possível objecto de saque e o tinham posto a salvo, enviando-o da sua terra para as mãos dos Bitínios, que eram seus amigos, avançou com o seu exército até à fronteira e enviou-lhes um arauto, para apresentar as suas queixas. Estes, tomados de medo, entregaram-lhe o saque e celebraram com ele um tratado de amizade.

30. 1. Ao impor um bloqueio a Calcédon, de mar a mar, Farnábazo acorreu, com o objectivo de romper o cerco; então, o governador Hipócrates saiu da cidade com todas as tropas que tinha consigo, para atacar os Atenienses $^{74}$. 2. Mas Alcibíades dispôs as suas tropas de modo a fazer frente a ambos. Levou Farnábazo a bater em retirada, coberto de vergonha, e, quanto a Hipócrates, matou-o, bem como a muitos dos seus soldados, após os ter vencido. 3. Em seguida, rumou

${ }^{74}$ Estes acontecimentos ocorreram em 409 a. C. Calcédon ficava na costa asiática frente a Bizâncio. Como "muro" entenda-se em parte uma paliçada, em parte o muro humano, formado pelo acampamento militar de Alcibíades (Xenofonte, Helénicas 1.3.4). 
para o Helesponto; aí lançou impostos e conquistou Selímbria, ocasião em que se expôs a perigo de vida. 4 . Aqueles que deviam entregar-lhe a cidade combinaram com ele erguer um archote aceso no meio da noite; todavia, viram-se obrigados a fazê-lo antes de tempo, com receio de um dos conjurados, que havia mudado inesperadamente de opinião. 5. No entanto, como o archote foi levantado quando o exército náo estava ainda preparado, Alcibíades tomou consigo trinta soldados que lhe estavam próximos e correu para as muralhas, depois de dar ordem aos restantes para que o seguissem rapidamente. 6. Foram-lhes abertas as portas e aos trinta soldados se juntaram outros vinte de infantaria ligeira. No entanto, ao entrar, Alcibíades apercebeu-se de imediato de que os habitantes de Selímbria se dirigiam em armas ao seu encontro. 7 . Vendo que não havia saída para um combate de resistência, mas sendo, ao mesmo tempo, demasiado orgulhoso para fugir - ele que até àquele dia se tinha mantido invencível nas suas campanhas - após ter dado ordem de silêncio por meio da trombeta, deu instruçôes a um dos que o acompanhavam para proclamar aos de Selímbria que não pegassem em armas contra os Atenienses. 8. Esta proclamação esfriou em alguns o ardor de combater, pois acreditaram que todo o exército inimigo se encontrava portas adentro da cidade, e a outros deu-lhes esperanças de que se chegasse a um acordo. 9. Enquanto se reuniam uns e outros e discutiam propostas, o exército de Alcibíades alcançou a cidade. Este, partindo do princípio, aliás verdadeiro, de que os habitantes de Selímbria estavam predispostos a manter a paz, tomou- 
se de receios que os Trácios pilhassem a cidade. 10. É que tinha muitos, no seu exército, que combatiam com ardor, por gratidão e amizade em relação à sua pessoa. Enviou-os, entâo, a todos, para fora da cidade e, tocado pelas súplicas dos Selímbrios, nenhum dano lhes fez. Limitou-se a exigir-lhes uma soma de dinheiro e a deixar ali uma guarnição, após o que se retirou.

31. 1. Os estrategos que mantinham o cerco a Calcédon chegaram a um acordo de paz com Farnábazo ,mediante as seguintes condiçóes: que lhes fosse entregue uma determinada quantia, que os Calcedónios voltassem a ficar sob o domínio dos Atenienses, mas que o território de Farnábazo não fosse, garantidamente, molestado e que Farnábazo proporcionasse, assim, uma escolta aos embaixadores dos Atenienses para estes se poderem apresentar em segurança diante do Rei. 2. Como Alcibíades estava, então, de regresso, Farnábazo achou por bem que também ele prestasse juramento de observância do tratado, mas Alcibíades negou-se a fazê-lo antes que o próprio Farnábazo o fizesse.

3. Uma vez prestados os juramentos, Alcibíades marchou sobre Bizâncio, que se havia revoltado contra Atenas, e pôs cerco à cidade. Posto que Anaxilau, Licurgo e alguns outros haviam acordado entregar-lhe a cidade, com a condição de a não arrasar, fez que se espalhasse a notícia da sua partida para a Iónia, por causa de revoltas que aí tinham surgido, e levantou ferro em pleno dia, com todos os navios; mas, noite caída, regressou e desembarcou ele mesmo com os hoplitas, aproximou-se 
das muralhas e aí se manteve em silêncio. Entretanto os seus navios dirigiram-se ao porto, onde forçaram a entrada, com grande alarido, tumulto e ruído. Assim assustaram os Bizantinos, colhendo-os de surpresa, e permitiram aos partidários de Atenas receber Alcibíades em segurança, pois toda a cidade tinha acorrido em defesa do porto e dos navios. 4. No entanto, o avanço de Alcibíades não se fez sem combate: é que os Peloponésios, Beócios e Megarenses instalados em Bizâncio fizeram retroceder os soldados que tinham desembarcado dos navios e forçaram-nos a voltar para bordo. Mas, quando se aperceberam de que os Atenienses se encontravam dentro dos muros da cidade, organizaram-se para o combate e avançaram ao seu encontro. 5. Deu-se entáo um violento recontro, do qual Alcibíades, à frente da ala direita, e Terâmenes, à frente da ala esquerda, saíram vencedores. Dos inimigos que sobreviveram tomou cerca de trezentos como prisioneiros. 6. Nenhum Bizantino foi morto ou exilado após a batalha, pois foi sob estas condiçóes que os partidários de Atenas $^{75}$ entregaram a cidade e, no que acordaram, não estabeleceram qualquer cláusula que os salvaguardasse ${ }^{76}$. 7. Por esse motivo, quando Anaxilau foi julgado na Lacedemónia sob

75 Sigo, neste ponto, a proposta de tradução de PÉREZ JimÉnez ("os partidários de Atenas"), por me parecer particularmente feliz. Descodificar hoi andres como "traidores" é inadequado para a atitude de quem garante a segurança da cidade, sem, contudo, pensar na sua própria - que o texto que segue ratifica.

${ }^{76}$ Nota Pérez Jiménez (2006) 180-181, n.147 que Plutarco segue, aqui, uma fonte diversa de Xenofonte, Helénicas 1.3, sendo mais evidente a coincidência de versôes com Diodoro Sículo 13.66.5-67.7. 
acusação de traição, transpareceu, nas suas palavras, que não se envergonhava pelo que havia feito. 8. Declarou que não era lacedemónio, mas sim bizantino, e que não era Esparta que ele tinha visto em perigo, mas Bizâncio, pois à cidade cercada nenhum auxílio lograva chegar e as provisóes que lá existiam eram os Peloponésios e os Beócios que as comiam, enquanto os Bizantinos passavam fome, com os seus filhos e as suas mulheres. $\mathrm{E}$ mais declarou que não tinha entregue a cidade a inimigos, mas que a tinha libertado da guerra e dos seus horrores, à imitação dos melhores entre os Lacedemónios, para quem só havia uma coisa bela e justa - o bem da pátria. Então os Lacedemónios, ao escutarem estas palavras, tomados de respeito, absolveram os acusados.

32. 1. Alcibíades sentia já saudades de rever a sua pátria mas, mais ainda, tinha vontade de se mostrar aos seus concidadãos, coberto de tantas vitórias sobre os inimigos. Por isso regressou com as trirremes áticas a circundá-lo, engalanadas com uma profusão de escudos e despojos, e fazendo-se seguir de uma quantidade de trirremes capturadas. Mais elevado era, no entanto, o número de figuras ornamentais de proa que transportava, correspondente a navios vencidos e destruídos por ele. Uns e outros, no total, não eram menos de duzentos. 2. Dúris de $\operatorname{Samos}^{77}$, que se dava por descendente de Alcibíades, acrescenta ainda estas informaçóes adicionais: o trabalho dos remadores era

${ }_{77}$ FGrH 76 F 76. Dúris foi discípulo de Teofrasto e foi, tal como Plutarco, que o cita frequentemente, um polígrafo. 
marcado pelo compasso da flauta tocada por Crisógono, vencedor de certames píticos, e quem dava as ordens era Calípides, actor de tragédia, ostentando ambos túnicas direitas, vestes adejantes e demais atavios próprios dos jogos. Mais ainda: a nau capitá entrou no porto ostentando uma vela cor de púrpura, como se viessem à frente de um cortejo dionisíaco, depois de se terem entregado à bebida. Estes factos não aparecem referidos por Teopompo, nem por Éforo, nem por Xenofonte, nem é verosímil que Alcibíades se entregasse a tais ostentaçóes perante os Atenienses, após um exílio e tantas vicissitudes. Pelo contrário - aportou receoso e, uma vez chegado, não deixou a sua trirreme antes de avistar em terra, chegando à ponte do navio, o seu primo Euriptólemo com um grande número de outros parentes e amigos que estavam ali para o acolher e o chamavam para terra.

3. Quando desembarcou, os que ali se juntaram pareciam náo dar conta da presença dos demais estrategos, pois acorriam na direcção de Alcibíades, gritando, acercando-se dele para o abraçar, o acompanhar e lhe oferecer coroas. Os que não conseguiam aproximar-se dele contemplavam aquele espectáculo de longe e os mais velhos indicavam-no aos jovens. 4. Mas a esta alegria da cidade misturava-se uma profunda tristeza e, perante a felicidade presente, recordavam-se desgraças anteriores. As pessoas comentavam que não se teria dado o fracasso na Sicília nem qualquer outro plano teria falhado se se tivesse mantido Alcibíades à frente dos assuntos militares, na altura, e daquele grande exército, já que, agora, ele tinha 
pegado de novo na cidade, quando esta estava praticamente privada do domínio marítimo, quando mantinha, em terra, com dificuldade, a posse dos seus subúrbios, e era destruída, internamente, por facçóes, e, no entanto, ele tinha conseguido erguê-la dos seus tristes e dilacerados escombros, para não só lhe devolver o poderio marítimo, como também para a levar a mostrar-se vitoriosa, em toda a parte, sobre os seus inimigos em terra.

33. 1 . O decreto que o chamava de volta já havia, de facto, sido proclamado tempos antes, sob proposta de Crítias $^{78}$, filho de Calescro, consoante este escreveu nas suas Elegias, recordando tal favor a Alcibíades nos seguintes versos ${ }^{79}$ :

A proposta que te conduziu de volta, eu mesmo a pronunciei, [publicamente, e por escrito a registei. Fui eu quem levou a cabo tal empresa. $O$ selo das minhas palavras está gravado nestes feitos.

2. Então, o povo reuniu-se em assembleia e Alcibíades compareceu perante ela. Com lágrimas e lamentos sobre os seus infortúnios, interpelou o povo apenas com suaves e moderadas censuras, deixando tudo por conta da sua má sorte e da inveja de alguma divindade. No entanto, o substancial das suas reflexóes centrou-se no avivar das esperanças dos cidadãos e no

${ }^{78}$ Crítias, tio de Platão, que, para além de compor elegias, foi também tragediógrafo. Em 404 a. C. foi posto, pelos Espartanos, à fente do governo tirânico dos Trinta.

${ }^{79}$ Frg. 3 Diehl. 
ânimo a incutir-lhes. Logo o coroaram com coroas de ouro e o elegeram estratego com plenos poderes em terra e no mar. 3. Foi votado que os seus bens lhe fossem devolvidos e que os Eumólpidas e os Cérices anulassem as maldiçóes que sobre ele tinham lançado por ordem do povo. Todos se retractaram, excepto Teodoro, o hierofante, que declarou: "No que me diz respeito, não lancei sobre ele maldiçóes, se não há injustiças de sua parte, cometidas contra a cidade!”.

34. 1. No entanto, enquanto Alcibíades desfrutava desta radiosa prosperidade, o momento do seu regresso deixava algumas pessoas preocupadas. Com efeito, o dia do seu desembarque coincidiu com o da celebração das Plintérias, em honra da Deusa ${ }^{80}$. Os Praxiérgidas têm a seu cargo a celebração destes ritos secretos no dia vinte e cinco do mês de Targélion ${ }^{81}$, após terem retirado à deusa os seus ornamentos e terem coberto a sua estátua com um véu. 2. Por isso os Atenienses contam este dia entre um dos mais nefastos e inadequado a qualquer empreendimento. Parecia, assim, que a Deusa não acolhia Alcibíades com disposição propícia e favorável, uma vez que se velava e o mantinha afastado dela.

3. No entanto, tudo corria a favor de Alcibíades, e cem trirremes, com as quais ele se preparava para partir

${ }^{80}$ As Plintérias eram festas celebradas em honra de Atena. O nome das festas (relacionado com o verbo plino, "lavar") indica que delas fazia parte uma lavagem ritual, fosse de estátua ou de vestes da deusa. Presidiam ao culto sacerdotes escolhidos no seio de uma família, a dos Praxiérgidas.

${ }^{81}$ Que corresponde, aproximadamente, ao mês de Maio. 
de novo, estavam a ser equipadas. Mas uma ambição, a que não era alheia uma dimensão de nobreza, reteve-o até à celebração dos Mistérios ${ }^{82}$. 4. Desde que Decelia tinha sido convertida num forte e que os inimigos que aí se tinham instalado passaram a dominar as vias de acesso a Elêusis, o cortejo solene era feito por mar, sem qualquer aparato, pois as circunstâncias obrigaram a que a prática dos sacrifícios fosse deixada de lado, assim como as danças e muitos outros rituais que, normalmente, tinham lugar ao longo do caminho por onde Iaco era levado em procissão ${ }^{83}$. 5. Entáo pareceu a Alcibíades que seria um belo gesto, no que diz respeito à veneração prestada às deusas eà sua própria fama perante os mortais, restituir às celebraçóes a sua forma original, fazendo que a procissão decorresse por terra, sob a protecção das suas armas quando passasse frente ao inimigo. Assim, desacreditaria e humilharia por completo Ágis, no caso de este não reagir, ou provocaria uma batalha santa e grata aos deuses, lutando pela causa mais sagrada e mais nobre aos olhos da sua pátria, e teria, assim, todos os seus concidadáos como testemunhas da sua valentia. 6. Uma vez tomada esta decisão, transmitiu-a aos Eumólpidas e aos Cérices. Postou sentinelas em pontos bem altos e, ao amanhecer, enviou uma guarda avançada. De seguida tomou consigo sacerdotes, mistas e mistagogos

${ }^{82}$ Estes celebravam-se no mês do Boedrómion, no início do Outono.

${ }^{83}$ Este cortejo era normalmente feito por terra, de Atenas a Elêusis, no dia 19 do Boedrómion, para transportar a estátua de Iaco (Dioniso) e os objectos sagrados, trazidos pouco antes de Elêusis. 
e, rodeando-os de tropas armadas, conduziu-os pelo caminho em boa ordem e em silêncio. Assim ofereceu, com esta expedição religiosa, um espectáculo tão solene e tão digno dos deuses que quem não nutrisse inveja de Alcibíades o apodava de ministério de hierofante e cerimónia de iniciação ${ }^{84}$. 7. Nenhum inimigo ousou atacá-lo e ele conduziu a procissão em segurança até à cidade. Tal êxito encheu-o de orgulho e empolgou de tal modo o seu exército que este se convenceu que era imbatível e invencível enquanto o tivesse como estratego. Além disso, ganhou a adesão incondicional do povo humilde e dos pobres, a ponto de estes desejarem ardentemente tê-lo como tirano. Houve mesmo quem lho dissesse e o encorajasse a passar por cima de invejas e abolir decretos e leis, calar conversas ocas que deitavam a cidade a perder, de modo a poder agir e lidar com os assuntos de estado sem temer os sicofantas.

35. 1. Ora o que ele mesmo pensava sobre a tirania não é claro. Todavia, os cidadãos mais poderosos foram tomados de receios e apressaram a sua partida, concedendo-lhe tudo o que ele tinha exigido e os companheiros que desejava. 2. Fez-se, então, ao mar com cem navios e assaltou Andros. Venceu os seus naturais e os Lacedemónios que ali se encontravam. No entanto, não tomou a cidade; e este foi o primeiro da nova série de ataques que os seus inimigos lhe dirigiram.

3. Parece que, se alguém se converteu em vítima

${ }^{84}$ Sigo a proposta de tradução do passo de Pérez JimÉNEZ, por me parecer particularmente feliz e realçar a ironia da situação. 
do seu próprio renome, essa pessoa foi Alcibíades. É que, por se ter tornado grande a fama da sua audácia e inteligência por via dos êxitos alcançados, no momento em que falhava em alguma iniciativa, ficava no ar a suspeita sobre a sua falta de empenhamento, pois ninguém acreditava tratar-se de insucesso por incapacidade. Se ele se tivesse empenhado, pensava-se, nada teria falhado. Ora os Atenienses alimentavam a expectativa de receber a notícia da tomada de Quios e do resto da Iónia. 4. Por esse motivo ficaram encolerizados quando tiveram conhecimento de que ele não tinha realizado tudo e de um momento para o outro, tal como desejavam. Não tiveram em consideração o facto de Alcibíades náo dispor de meios e de mover guerra contra gente que tinha no Rei um grande corego ${ }^{85}$, sendo muitas vezes forçado a deixar o acampamento e fazer-se ao mar para conseguir proventos e provisóes para as suas tropas. 5. Aí residiu a causa da última acusação de que foi alvo. Lisandro, que foi enviado pelos Lacedemónios à frente de uma armada para o combater, pagava a cada marinheiro quatro óbolos, em vez de três, por conta do dinheiro que recebera de Ciro. Alcibíades, que já tinha dificuldade em pagar três óbolos aos seus homens, partiu para a Cária, a fim de aí conseguir dinheiro. 6. O homem a quem ele deixou o comando da armada, Antíoco, era um bom piloto, mas, de resto, não passava de um homem tolo e grosseiro. Tinha ordens de Alcibíades para não se envolver em combates navais,

${ }^{85}$ Tal como Pérez Jiménez (2006) 188 n. 165 "preferimos mantener este término que alude a las contribuciones fiscales de los atenienses com las que sufragavan los gastos públicos". 
ainda que o inimigo o provocasse. Mas a sua soberba e menosprezo pelo inimigo eram tais que equipou a sua própria trirreme e uma das restantes e dirigiu-se a Éfeso. Ao passar ao longo das proas inimigas ia-se exibindo em palavras e gestos prolixos de descomedimento e de bravata. 7. De início, Lisandro fez-se ao mar com umas poucas naus, em sua perseguição. Então os Atenienses vieram em auxílio de Antíoco e Lisandro pôs no mar toda a sua esquadra e venceu-os. Matou Antíoco, aprisionou um grande número de navios e de homens e ergueu um troféu. 8. Assim que Alcibíades tomou conhecimento dos factos, voltou a Samos, fez-se ao mar com toda a sua esquadra e desafiou Lisandro para uma batalha naval. Mas Lisandro estava satisfeito com a sua vitória e não respondeu ao seu desafio.

36. 1. No acampamento havia quem odiasse Alcibíades. Era o caso de Trasibulo, filho de Tráson ${ }^{86}$, que era seu inimigo e partiu para Atenas, para o acusar. 2. Depois de acirrar os ânimos dos cidadãos, declarava, perante o povo, que tinha sido Alcibíades quem havia arruinado os interesses da cidade e deitado a perder a armada, por ter negligenciado os seus deveres de chefia e entregado o comando nas mãos de homens que ganharam enorme influência graças aos hábitos de bebida e fanfarronices de marinheiros. Assim, segundo Trasibulo, podia ele mesmo navegar por onde lhe aprouvesse e arrecadar riquezas, para dar largas aos seus

86 Trata-se de um outro Trasibulo, que não o anteriormente mencionado por Plutarco, que combateu às ordens do primeiro, aquando do restabelecimento do regime democrático. 
vícios, entregando-se à bebida e ao prazer, nos braços das cortesãs de Abidos e da Iónia, enquanto os navios do inimigo se encontravam ancorados nas proximidades. 3. Censuravam-no, também, por ter erguido uma fortaleza na Trácia, cerca de Bisante, para lhe servir de refúgio, como se não pudesse ou não quisesse viver na sua pátria. 4. Ora os Atenienses deixaram-se persuadir e elegeram outros estrategos, manifestando, assim, a sua cólera e animosidade contra ele. 5. Ao ser informado destes acontecimentos, Alcibíades, tomado de receios, abandonou definitivamente o acampamento. Reuniu um grupo de mercenários e passou a combater, por sua conta, os Trácios que não estavam submetidos ao poder régio. Assim, com o espólio dos combates acumulou grandes riquezas e, ao mesmo tempo, garantia aos Gregos da região protecção contra os Bárbaros.

6. Os estrategos Tideu, Menandro e Adimanto tinham reunido em Egospótamos todos os navios de que os Atenienses então dispunham e costumavam fazer-se ao mar ao romper do dia para irem provocar Lisandro, que estava ancorado cerca de Lâmpsaco. De seguida, regressavam ao lugar onde estava fundeada a armada ateniense e aí passavam o dia, sem disciplina nem cuidado, como quem ignora o inimigo. Alcibíades, que se encontrava nas cercanias, náo pôde saber desta conduta e ignorá-la, sem com ela se preocupar. Veio, a cavalo, chamar a atenção dos estrategos para o facto de terem escolhido mal o lugar que lhes servia de ancoradouro, sem terem, nas proximidades, um porto ou uma cidade, pelo que se viam obrigados a 
ir procurar provisóes em Sesto, e, assim, deixavam que os marinheiros, ao desembarcar, vagueassem e se dispersassem por onde lhes apetecia - e isto quando, na frente deles, tinham estacionada uma armada enorme, habituada a tudo fazer em silêncio, ao sinal de ordem de um só comandante.

37. 1. Foram estas as advertências de Alcibíades, que os aconselhou a fundear a armada em Sesto. Não lhe prestaram ouvidos os estrategos e Tideu levou mesmo a sua insolência ao ponto de lhe ordenar que partisse, pois já não era ele, Alcibíades, mas outros os generais que chefiavam o exército. 2. Para Alcibíades tomaram corpo as suspeitas de traiçáo da parte dos estrategos e, por isso, partiu. Mas aos seus conhecidos que o escoltaram para fora do acampamento garantiu que, se não tivesse sido ultrajado daquela forma pelos estrategos, em poucos dias teria forçado os Lacedemónios a um confronto naval, ainda que contrariados, ou ao abandono das naus. 3. A uns, estas palavras pareciam fanfarronice; a outros, porém, parecia ter sentido o que ele dizia, pois podia arrastar consigo um grande número de lanceiros e cavaleiros trácios, dar-lhes combate e semear a confusão no acampamento lacedemónio. 4. Que ele viu, com exactidão, as falhas dos Atenienses, demonstraram-nos os factos que, logo depois, se seguiram. É que Lisandro caiu de súbito, sem se fazer esperar, sobre eles e só conseguiu escapar Cónon, com oito trirremes. Todos os outros homens - cerca de duzentos - foram feitos prisioneiros. 5. No que diz respeito aos soldados, Lisandro capturou vivos trezentos, que executou. 
Em pouco tempo Lisandro conquistou Atenas, queimou a armada ateniense e destruiu a extensa muralha ${ }^{87}$.

6. Depois destes acontecimentos, Alcibíades, temendo os Lacedemónios, já senhores da terra e do mar, transferiu-se para a Bitínia. Muitas foram as riquezas que para lá fez transportar, muitas as que levou consigo e mais ainda as que deixou no forte em que tinha habitado. 7 . $\mathrm{Na}$ Bitínia perdeu de novo muitos dos seus bens, vítima da pilhagem dos Trácios daquela região. Decidiu então penetrar na Ásia, até à corte de Artaxerxes. Animava-o a ideia de que, se o Rei o pusesse à prova, não se mostraria inferior a Temístocles e, quanto aos seus motivos, até superior. 8. É que não seria contra os seus concidadãos, como Temístocles, mas a favor da sua pátria e contra os inimigos dela que ele se punha ao serviço do Rei e invocava o seu poder. Na convicção de que era Farnábazo a pessoa certa para lhe facilitar uma viagem em segurança até ao Rei, foi ter com aquele à Frígia e passou algum tempo na sua companhia, entre a adulação de que o rodeava e as honrarias que dele recebia.

38. 1. Os Atenienses suportavam com dificuldade o facto de se verem privados da sua hegemonia, mas quando Lisandro os privou da sua liberdade e entregou a cidade de Atenas ao mando de trinta homens, as reflexôes que não haviam feito quando ainda estavam a tempo de se salvar, ocorreram aos seus espíritos, agora que tudo estava

${ }^{87}$ A batalha de Egospótamos, travada em 405 a. C., onde os Atenienses são duramente vencidos pelas forças espartanas, apoiadas pelos Persas e lideradas por Lisandro, constitui, por assim dizer, o epílogo da Guerra. 
perdido. Lamentavam, revendo-as nas suas memórias, os erros e faltas cometidos, entre os quais consideravam como o mais grave a sua segunda reacção de cólera contra Alcibíades. 2. Alcibíades tinha sido repudiado sem que tivesse havido qualquer culpa da sua parte - antes, irados contra um subalterno que tinha deitado a perder, de maneira vergonhosa, uns tantos navios, de modo mais vergonhoso ainda tinham eles mesmos privado a Cidade do melhor e mais corajoso estratego. 3. E, no entanto, a despeito da situação presente, alimentavam uma ténue esperança de que a causa ateniense náo estivesse de todo perdida enquanto Alcibíades permanecesse vivo. É que, diziam eles, se no seu primeiro exílio Alcibíades não se contentou em levar uma vida ociosa e tranquila, também agora não iria tolerar, se dispusesse de meios suficientes, a insolência dos Lacedemónios e os desmandos dos Trinta.

4. De resto, estes sonhos do povo não eram destituídos de razão, já que também os Trinta estavam tomados da mesma preocupação e colhiam informaçóes, seguindo, com todo o interesse, os movimentos e os planos deAlcibíades. 5. Por fim, Crítias fez perceber a Lisandro que, caso a democracia se restabelecesse em Atenas, não estava garantido, para os Lacedemónios, o domínio da Hélade e que, ainda que os Atenienses mostrassem uma disposição dócil e favorável em relação à oligarquia, Alcibíades, enquanto estivesse vivo, náo os deixaria acomodarem-se tranquilamente a esta ordem instituída. 6. No entanto, Lisandro não se deixou levar por estes argumentos, até ao momento em que recebeu dos magistrados de Esparta uma 
escítala $^{88}$ com ordem de se desembaraçar de Alcibíades, fosse por também os Lacedemónios temerem a agudeza de espírito e a capacidade de empreendimento deste homem, fosse por quererem agradar a Ágis.

39. 1. Lisandro enviou, então, a Farnábazo uma mensagem em que solicitava a execução desta ordem. $\mathrm{O}$ Persa encarregou seu irmáo Bageu e seu tio Susâmitres desta missão. Ao tempo Alcibíades encontrava-se numa aldeia da Frígia, onde vivia com a cortesã Timandra e onde teve a seguinte visão enquanto dormia: 2 . viu-se a ele mesmo, num sonho em que parecia envergar as vestes da cortesã, e a esta, em cujo regaço reclinava a sua cabeça, enquanto ela lhe compunha o rosto, aplicando-lhe cosmética, como se fosse uma mulher, e lhe penteava os cabelos. 3. Outros autores dizem que ele viu, em sonhos, Bageu, que lhe cortava a cabeça e puxava fogo ao seu cadáver, mas todos coincidem num ponto: o sonho ocorreu pouco antes da sua morte.

4. Os homens que foram enviados com a missão de matar Alcibíades náo se atreveram a entrar em sua casa antes a cercaram e deitaram-lhe fogo. 5. Então, quando Alcibíades se apercebeu do que se passava, juntou quanto pôde das suas roupas e cobertas e lançou-as sobre o fogo. De seguida, enrolou a sua clâmide à volta do braço

${ }^{88}$ A escítala (gr. skytale) era um bastão utilizado pelos magistrados espartanos para enviar secretamente ordens aos generais que estivessem no exterior. $\mathrm{O}$ texto era gravado sobre uma fina tira de couro, enrolada oblíquamente à volta do bastáo. Só aquele que possuísse bastão de iguais dimensóes e espessura podia decifrar a mensagem, ao desenrolá-la e enrolá-la no seu próprio bastão. 
esquerdo e, desembainhando com o direito o seu punhal, lançou-se ele mesmo para o exterior, incólume, pois o fogo não tinha ainda incendiado as roupas. Àvista de Alcibíades os Bárbaros dispersaram. 6. É que nenhum de entre eles se atreveu a fazer-lhe frente ou a travar com ele combate; só o atacaram arremessando contra ele, à distância, dardos e flechas. 7. Quando Alcibíades sucumbiu, deste modo, e os Bárbaros se afastam, Timandra recolheu o seu cadáver, envolveu-o e cobriu-o com as suas próprias túnicas e, tendo em conta as circunstâncias, preparou-lhe exéquias brilhantes e dignas. 8 . Diz-se que desta mulher nasceu uma filha, Laís, conhecida como "a Coríntia", embora fosse uma prisioneira de guerra de Hícara, uma cidadezinha da Sicília.

9. Alguns autores, no entanto, embora coincidam globalmente com esta versão da morte de Alcibíades, afirmam que não foi Farnábazo, nem Lisandro, nem sequer os Lacedemónios quem esteve na origem dos factos, mas o próprio Alcibíades que, depois de seduzir uma jovem pertencente a uma família conhecida, a mantinha consigo. Então, os irmáos desta, exasperados com tal agravo, atearam fogo, durante a noite, à casa em que Alcibíades vivia e abateram-no, conforme se acabou de contar, quando ele tratava de escapar através das chamas. 
Vida de Coriolano 
(Página deixada propositadamente em branco) 


\section{INTRODUÇÃO}

O enredo que dá forma à história de Coriolano é supostamente passado em 493 a.C. e é o mais antigo caso conhecido de um cidadão de Roma que renuncia à sua cidade pátria. Gaio Márcio é um general romano que se opóe às reformas que, na cidade, tentam favorecer a plebe ${ }^{1}$. Na sequência de vários acontecimentos, de entre os quais se destaca a tomada de Coríolos que lhe vale o epíteto de "Coriolano», e depois de afirmar a sua posiçáo, Márcio é banido da sua própria cidade, para se aliar aos Volscos, povo que há muito era inimigo de Roma. É Coriolano quem incentiva os Volscos a fazerem a guerra aos Romanos, assumindo inclusivamente o comando das tropas ao mesmo tempo que um projecto de vingança/traição. Reúnem-se então as condiçôes para conquistar Roma, mas, antes de tomar a cidade, a máe e a mulher de Coriolano vêm até ele como suplicantes e convencem-no a abandonar a ideia de conquistar aquela que afinal é a sua pátria. Nesse momento, impressionado pelas palavras e pela acção das mulheres, Gaio Márcio recua e desiste do ataque. Segundo uma das tradiçôes, acabou por ser assassinado pelos próprios Volscos.

A história de Coriolano foi, na Antiguidade, contada por vários autores e a personagem foi citada

1 Algumas fontes referem «Gneu» e não «Gaio». Plutarco, porém, usa «Gaio». 
amiúde com intençôes éticas e políticas. Mas o mais curioso é que a figura do general romano nem sempre foi usada com os mesmos objectivos, sendo umas vezes evocada como exemplo de heroísmo positivo, outras vezes como protótipo de negatividade pela traição que assumira contra Roma. Cícero, por exemplo, o autor mais antigo conhecido a referir-se a Coriolano, tem-no fundamentalmente como o protótipo do traidor e a imagem que definiu no século I a.C. manteve-se durante muito tempo e como modelo para vários outros autores antigos ${ }^{2}$. Já Tito Lívio apresenta Coriolano como um dos heróis do passado romano, ainda que com uma história infeliz: um grande general mas um estadista falhado ${ }^{3}$. Sendo Tito Lívio um simpatizante dos patrícios, compreende-se a razão por que toma tal posição. Esta perspectiva foi particularmente importante no Nachleben de Coriolano, uma vez que Tito Lívio foi o primeiro autor conhecido a contar a história da personagem de uma forma exaustiva, definindo, portanto, os seus pontos axiais: os feitos militares, a oposição à plebe, o exílio, o cerco de Roma e a intervenção das mulheres. Assim se explica também por que motivo Lívio toma Coriolano como um exemplum didáctico e moral. Seguindo a linha liviana, Dionísio de Halicarnasso, nas suas Antiguidades Romanas, publicadas em 7 a.C., introduz Coriolano igualmente como uma das figuras

${ }^{2}$ Cícero, Cartas a Ático 9, 10, 3; Da amizade 11, 36; 12, 42. Ver ainda Aulo Gélio, Noites Áticas 40; Ampélio 27; Eutrópio 1, 14-15.

${ }^{3}$ Tito Lívio, Desde a fundação da cidade 2, 33-40. 
proeminentes do passado remoto de Roma ${ }^{4}$. Em síntese, podemos afirmar que o Coriolano de Dionísio é um homem cuja vida acaba de uma forma trágica porque foi incapaz de conciliar os seus ideais éticos e políticos com as concepçôes da plebe maioritária ${ }^{5}$. Mas isso não obsta a que ele seja visto como um dos grandes homens do seu tempo, um verdadeiro símbolo do guerreiro superior. A forma patética como Dionísio de Halicarnasso descreve a morte de Márcio enquadra-se no espírito da historiografia helenística, optando por enaltecer as virtudes do herói e fazendo dele um verdadeiro modelo de justiça e piedade. Esta perspectiva foi mantida por Valério Máximo, que nos seus Facta et dicta memorabilia narrou a história do general com objectivos didácticos e moralizantes, acentuando sobretudo a piedade filial da personagem, através de expressóes como Coriolanus maximi uir animi et altissimi consilii ${ }^{6}$.

Mas deve-se a Plutarco, no início do século II d.C., o mérito de reconhecer tanto as características positivas como as negativas de Coriolano, recriando assim um novo modelo que viria a ser seguido posteriormente ${ }^{7}$.

${ }^{4}$ Dionísio de Halicarnasso, Antiguidades Romanas 5-8.

${ }^{5}$ Lehman (1952) 331.

${ }^{6}$ Valério Máximo 1, 8, 4; 4, 3, 4; 5, 2, 1; 5, 4, 1 (onde se lê a citação: "Coriolano, homem de grande alma e de elevada sabedoria»).

7 O tema foi ainda referido ou tratado por outros autores antigos, como Floro 5, 9; Díon Cássio, frg. 5, 1618; e Aurélio Victor 2, 19, 1-3. Ver Lehman (1952) 334-335. As Vitae de Alcibíades-Coriolano deverão ter sido das últimas a serem escritas por Plutarco, visto que tratam mais os vícios do que as virtudes e o autor só deverá ter-se decidido a escrever sobre aqueles depois ter já um elenco suficientemente grande de personagens que 
Ao escolher a figura do general romano para integrar o elenco das Vitae, alinhando-o com o estadista grego Alcibíades, Plutarco adopta o que foi já reconhecido como uma "terceira atitude» ${ }^{8}$, apresentando a personagem como uma figura de grandes potencialidades e capaz de atitudes positivas, mas também detentora de um carácter que chega a ser misantrópico e egoísta. Uma das primeiras frases escritas por Plutarco nesta Vita testemunha a perspectiva do seu autor:

Este mesmo homem deu testemunho dos que acreditam que a natureza, ainda que nobre e boa, se for desprovida de educação, produz muitas coisas boas, mas também más, tal como acontece na agricultura, quando um terreno fértil é abandonado sem cuidados $(1,3)$.

Na verdade, o que Plutarco traz de novo à caracterização psicológica de Coriolano é a complexidade do ethos do herói, ao humanizar a sua personalidade, por meio de um tema claramente platónico'. Se por um lado o general romano é aquele cuja instabilidade, ira e desejo de vingança controlam as suas decisôes e motivam os seus impulsos, por outro é também o homem que desespera por ser compreendido nas posiçóes que toma, cujo patriotismo é mal entendido pelos concidadãos e cuja alma mantém imaculado o amor filial. Amor

exemplificassem estas. Ver Crespo (2003) 34-36.

${ }^{8}$ Lehman (1952) 333.

${ }^{9}$ Ver Platão, A República 491a-e, onde lemos «que as almas mais bem dotadas, se se lhes deparar uma educação má, se tornam extremamente perversas» (trad. M.H. da Rocha Pereira). 
esse que acabará por ser "ardilosamente» usado para neutralizar aquele que poderia ter vindo a ser o carrasco de Roma. Isto é, Plutarco retrata Coriolano com os matizes de um carácter trágico-patético, latente na essência da personagem, que acabarão por proporcionar a Shakespeare a matéria-prima para uma das suas obras fundamentais, Coriolan, centrada na ambição, na busca das honras e na ira. Segundo o biógrafo de Queroneia, esta dialéctica entre a philotimia e a orge é motivada pelas falhas ao nível da educação, em particular da paideia grega, que fizeram com que Coriolano se mantivesse sempre um bárbaro, ainda que nobre ${ }^{10}$. Como nota Frazier, Coriolano é um velho romano dos tempos heróicos, magnânimo, obstinado, mas associal e privado das luzes da cultura ${ }^{11}$. Vários hermeneutas contemporâneos, aliás, têm salientado que o objectivo da vida de Coriolano está precisamente em demonstrar o desastre que pode acontecer quando um homem de grande natureza se desvia do caminho certo por falta de uma educação adequada: os grandes espíritos ou alcançam uma grande glória ou uma grande destruição, quando as Musas são dispensadas e as paixóes dominam a razão e vencem a temperança ${ }^{12}$. Esta posição vai ao encontro do que se tem dito acerca da relaçáo de Plutarco com o estoicismo. De facto, à negação estóica do valor das paixões,

${ }^{10}$ Russell (1963) 27; Löв, Lerner (1977); Swain (1990) 131, 135-137; Pinheiro (2009) 360. Seguindo o que Plutarco escreve em 15, 4, este ultimo autor refere ainda a philanthropia e a praotes (doçura ou bondade) como falhas graves no ethos de Gaio Márcio.

${ }^{11}$ Frazier (1992) 4531.

12 Plutarco, Coriolano 1, 5; Nerdahl (2007) 110, 120-121, 149. 
Plutarco opóe uma crítica que assenta numa concepção de natureza humana e das paixóes que se define pela reabilitação dos sentimentos e das emoçóes. Como tal, o autor defende a ideia segundo a qual as paixôes fazem parte da natureza humana e são indispensáveis para o seu desenvolvimento moral, enquanto a apatheia estóica não passa de uma utopia que define a condição ideal do sábio para alcançar a virtude ${ }^{13}$. O segredo estará, portanto, em saber fazer uso das paixóes, anulando as malignas e deixando sobressair as que são sintoma de uma boa natureza. Apesar de ter demonstrado apatheia para com os prazeres, sofrimentos ou riquezas, e isso ser sinal de uma sensibilidade helénica antes da helenização de Roma, Coriolano não terá conseguido seguir a norma preferida de Plutarco, o que, na perspectiva do biógrafo, teria originado a sua catástrofe $(1,3-6 ; 15$, 45). Apesar de ser deficitário em educação helénica, e de aparentemente nem nela estar interessado, a Gaio Márcio não faltam contudo capacidades oratórias evidentes. Trata-se, como é óbvio, de uma interpretatio plutarquiana da personagem, que, aliás, deve bastante à forma como Dionísio a tratou antes.

De certo modo, o exílio de Márcio bem como a sua proximidade a culturas estranhas por imposição de terceiros, o contacto com o Outro supostamente «bárbaro», é precisamente uma metáfora da ausência de paideia $^{14}$. Por outro lado, a tragédia de Coriolano

${ }^{13}$ Parte destas ideias pode ler-se no tratado Acerca da virtude moral (Moralia 440d).

${ }_{14}$ Outros exilados plutarquianos são Temístocles, Sertório e Alcibíades, precisamente o par de Coriolano. Historicamente, 
assenta sobretudo na ira e não no exílio ou na pátria, pois é aquela que influencia as suas atitudes para com estes e não o oposto. Ainda que a atitude de Márcio em relação à pátria seja no essencial contrária à de outros biografados por Plutarco, como Rómulo, César, os Gracos ou Péricles. Por isso também, este herói/ anti-herói plutarquiano, cheio de contradiçóes e dilemas, não é tanto um agente da História quanto uma personagem moral e actuante. Trata-se de um exemplo acabado da transformação da historiografia em biografia moralizante.

$\mathrm{O}$ método encontrado por Plutarco para esta formulação baseia-se numa construção dualista do texto, em que a primeira parte sugere fundamentalmente um herói magnânimo e exemplo a ser seguido, uma verdadeira "teoria mimética da moral» de inspiração platónica $^{15}$ na linha liviana ou dionisíaca, enquanto a segunda o transforma numa figura rejeitada, num homem de paixóes incontroláveis que acaba por se revelar o mais perigoso dos inimigos de Roma, tal como Cícero havia já delineado. Náo deixa ainda de ser pertinente

porém, o exílio junto dos Volscos talvez fosse pouco significativo em termos culturais, uma vez que a origem destas tribos seria itálica e que o osco, o úmbrio e o latim (e o volsco, língua considerada próxima do úmbrio) formavam o que os linguistas designam por ««línguas itálicas». Sobre esta questão, ver MAYer (1997) 49 e T. Janson, A Natural History of Latin (Oxford, University Press, 2004) 10 .

15 Conceito usado por Frazier (1992) 4489. Segundo esta autora, as razóes pelas quais Plutarco apresenta modelos e anti-modelos, a seguir ou a evitar, são indissociáveis, visto que para o escritor grego seremos melhores imitadores dos primeiros se não desconhecermos os segundos. 
que Plutarco faça alinhar a vida de um herói romano semilendário, ainda que os Antigos eventualmente o não considerassem assim, com um estadista do período áureo ateniense. De certa forma, isso explica-se por Plutarco muito provavelmente encarar o período da vida de Coriolano como o de uma Roma áurea, com grandes semelhanças com a Atenas do século V a.C., apesar de pré-helenizada ${ }^{16}$.

No âmbito da Quellensforschung plutarquiana, vários autores consideram que a Vida de Coriolano proporciona uma oportunidade ímpar para estudar o método do autor de Queroneia, uma vez que só raramente, se não apenas desta vez, Plutarco recorreu a uma única fonte ou autoridade para escrever uma biografia ${ }^{17}$. De facto, parece ter sido precisamente isso que aconteceu neste caso, composto essencialmente a partir da narrativa de Dionísio de Halicarnasso (livros $\mathrm{V}$ a VIII) ${ }^{18}$. Talvez esta opçáo se tenha devido ao facto de o historiador augustano ter dado particular atenção à figura de Coriolano, por oposição a Tito Lívio, que todavia lhe dedica pouco espaço nas sua história de Roma. Ainda assim, reconhece-se nesta Vida uma parte considerável que corresponde a material não importado de Dionísio, como apontamentos arqueológico-linguísticos, digressôes filosóficas e reflexôes morais, de que são

${ }^{16}$ Ver Geiger (1981).

${ }^{17}$ Russell (1963) 21; cf. Smith (1940) e Pelling (1979), que estudaram as vidas romanas que foram alvo de um tratamento e metodologia diferentes da de Coriolano.

${ }^{18}$ Este historiador é referido pelo nome na comparação entre Coriolano e Alcibíades (2, 4). 
exemplos os parágrafos dedicados à onomástica (11), à inspiração divina (32) e aos milagres (38). Este foi já reconhecido também como um método tipicamente plutarquiano $^{19}$. De igual modo, devem ser assinaladas as diferenças detectadas ao nível dos nomes de algumas das figuras reportadas, como o da mãe de Coriolano (Vetúria em Dionísio, Volúmnia em Plutarco, 4) e o da mulher (Volúmnia em Dionísio, Vergília em Plutarco, 33). Este elemento sugere que o Queronense nem sempre seguiu a lição de Dionísio de Halicarnasso, apesar de dificilmente ter recorrido a uma terceira fonte. Isto é, o que não é dionisíaco no Coriolano de Plutarco, muito provavelmente é tâo-somente da autoria e iniciativa do biógrafo, confirmando a sua originalidade e liberdade na composição do texto ${ }^{20}$. Como foi já assinalado, o autor formulou a sua própria interpretação do carácter do herói e impô-la à sua versão dos acontecimentos ${ }^{21}$. Para o efeito, ele dispensa o rigor histórico, preocupando-se mais com a construção psicológica das personagens. Por isso mesmo não serão de estranhar as referências historicamente menos correctas nas Vidas, simplesmente porque Plutarco dispensou a precisão cronológica, em benefício de outros aspectos que considerou mais importantes. Talvez resida aqui um dos elementos para distinguir o biógrafo do historiador.

${ }^{19}$ Cf. e.g. Rómulo 26, 28, Numa 4; Publícola 15; Camilo 19, apud RusSELl (1963) 21, n. 5.

${ }^{20}$ Pelling (1997) 14-15.

${ }^{21}$ Russell (1963) 22. Este autor fala de «aumento», «resumo», «transposição» e "reinterpretação», ao nível da narrativa importada. Ver o artigo citado para exemplos do recurso a estas metodologias. 
Com efeito, a relação entre Romanos e Volscos é uma problemática historicamente complexa, que se denuncia na vida de Gaio Márcio, tal como se insinuara antes na figura de Camila, a virgem guerreira celebrizada por Vergílio na Eneida. Como refere T. J. Cornell, o nosso conhecimento da sociedade e da cultura volsca é muito exíguo. Os vestígios onomásticos sugerem que os Volscos eram um povo itálico, que havia migrado de norte para sul, vindo do maciço apenino, em finais do século VI a.C. As referências linguísticas provêm sobretudo da chamada tabula Veliterna, uma inscrição de quatro linhas sobre bronze proveniente de Velitras e datada do século III a.C. A língua em que está escrita é por norma entendida como o volsco, sendo-lhe reconhecidas afinidades com o úmbrio. Por essa razão, os filólogos costumam atribuir uma origem nortenha aos Volscos e sugerem a sua migração de norte para sul. Mas não está fora dos horizontes dos historiadores contemporâneos considerar que a presença deste povo no sul da Península Itálica se tenha devido a uma migração do interior para o litoral, durante o século V a.C. As incursóes de Sabinos, Équos e Volscos no Lácio durante esse período são assim entendidas como manifestaçoóes desse fenómeno. Os Volscos, em particular, ocuparam as cidades do sul daquela regiâo durante os anos 90 do século $\mathrm{V}$ a.C. Estas guerras tiveram um efeito desastroso na economia e sociedade romanas e latinas em geral. Um dos ataques mais sérios terá sido o que decorreu entre 490 e 488 a.C., em que os Volscos invadiram o território latino e o devastaram. Muito provavelmente, a história de Coriolano traduz 
uma memória popular genuína em que aquelas incursóes e ataques ameaçaram de facto a própria existência de Roma ${ }^{22}$. Em contrapartida, foram já apontados argumentos que fazem com que se saliente mais o carácter lendário da vida de Coriolano que a sua factualidade histórica, designadamente: a baixa probabilidade de os Volscos terem escolhido um exilado romano para um dos seus generais e de lhe reconhecerem vitórias; a confusão com Gélon de Siracusa $(16,1)$; a anacrónica influência de um suposto jovem Coriolano no senado; a atribuição de um cognomen a Gaio Márcio, quando isso parece ter sido uma prática posterior; o anacronismo dos comitia tributa (20, 1-4); a identificação de Coríolos como cidade volsca, quando na realidade era latina; a improbabilidade de a sua conquista ter ocorrido em 493 a.C., e às máos de outro general que não um dos cônsules em exercício; a inverosimilhança de tantas cidades conquistadas em táo pouco tempo (como mencionado em 28, 5) ${ }^{23}$. Ainda

${ }^{22}$ Cornell (1995) 304-307; Salmon (1930).

${ }^{23}$ Salmon (1930). Este mesmo autor salienta que se partirmos do princípio de que Coriolano era volsco e náo romano, alguns aspectos passam a fazer mais sentido. Em defesa desta hipótese, ele lembra que, segundo Dionísio de Halicarnasso, Antiguidades Romanas 8, 63, os Volscos cultuavam a memória de Gaio Márcio e tinham cançóes sobre ele. Teria sido a vaidade romana a transformar o volsco Gaio Márcio num romano e, por conseguinte, a derrota dos Romanos a consequência dos feitos de um romano? Relativamente à eventual manipulação das datas no episódio de Coríolos, deverá ter-se em conta o contexto político de 446 a.C. e a disputa pela cidade nessa data. A verificar-se esse carácter lendário, e são vários os argumentos que o defendem, não esqueçamos que ele estava já presente na fonte de Plutarco, Dionísio de Halicarnasso. O biógrafo limitou-se a recolher as informaçóes, mantendo-se acrítico quanto aos aspectos aqui referidos. 
assim, permanece a hipótese de a essência da história corresponder à realidade histórica.

Igualmente presente na biografia de Coriolano, o método de apresentar a narrativa com recurso à inclusão de grandes cenas de influência teatral consubstancia-se na intervenção de Volúmnia junto do filho (34-36). Esta é uma cena composta por diversos elementos retóricos: a descrição da emoção do herói; o reencontro de mãe e filho, de mulher e marido e filhos e pai; o longo discurso da matrona; os significativos e inéditos silêncios de Coriolano; a prostraçáo da família do general; o reconhecimento por parte do herói de que a mãe venceu com os seus argumentos e, de certa forma, "chantagem moral», e a renúncia à vingança. Mas, ao mesmo tempo, é uma cena despojada de elementos acessórios que possibilitem uma eventual distracção do leitor da questão verdadeiramente central. Este é, aliás, um dos grandes exemplos de uma técnica muito característica das Vidas plutarquianas e sem dúvida a mais vívida de todas as cenas da biografia, em que o pathos se revela de forma melodramática. Note-se como tudo decorre entre Coriolano e a mãe, apesar da multidão composta por homens e mulheres que os rodeia. A súplica da família contrasta com a contenção inicial do homem, para tudo se alterar no final, com a quebra da rigidez de Coriolano, através do simples «Ganhaste!» que dirige à progenitora $(36,5)$. Este tipo de encenação sugere igualmente a retórica teatral, em que as personagens são apresentadas como se estivessem 
em cima de um palco, rodeadas por um coro ${ }^{24}$. Outras vezes, é a ênfase colocada sobre um gesto que marca essa teatralidade, tão característica da historiografia helenística $^{25}$. Já referimos o momento em que a família de Coriolano cai de joelhos à frente do paterfamilias (36, 5), mas podemos evocar outros momentos, como aquele em que Tulo estende a sua mão direita a Coriolano para selar a aliança entre ambos $(23,9)$.

É também na moldura dessa teatralidade que se contextualiza o já mencionado ethos trágico de Coriolano. O dilema interior do herói, que se debate sob a camuflagem de uma ira auto-destrutiva entre a tão ambicionada vingança e o respeito e o amor pela pátria e pelos seus, quase que destrói a personagem, corroendo-a por dentro. $\mathrm{O}$ final de Coriolano, tal como Plutarco o apresenta, assassinado às máos dos Volscos,

${ }^{24}$ Outras grandes cenas da Vida de Coriolano são a da outorga do cognomen ao herói (\$10-11), a da condenação de Coriolano à morte (\$17-18), a da aliança de Tulo e Coriolano (\$22-23) e a das mulheres que, lideradas por Valéria, decidem intervir (\$33). Sobre esta questão, ver Frazier (1992).

${ }^{25}$ Cf. Lacy (1952); Walbank (1960). Frazier (1992) 4525, porém, considera de modo pertinente que apesar de Plutarco se inspirar na historiografia helenística, existe nele também uma rejeição da tendência reconhecida nesse estilo historiográfico, ao recusar o patético excessivo, preferindo a sublimação, em que a elevaçáo moral se faz com recurso a tópicos em que se percebem ressonâncias trágicas. Em contrapartida, as descriçóes fornecidas por Dionísio de Halicarnasso são bem mais contidas. Os seus comentários contribuem também para que se formulem juízos acerca das figuras e situaçóes. A ausência desses mesmos comentários em Plutarco, porém, traduz a manipulação da obra do historiador de Halicarnasso por parte do biógrafo de Queroneia e potencia o dramatismo numa perspectiva trágica por parte do leitor. 
antes aliados depois de terem sido inimigos, é um final digno do ambiente trágico. Coriolano recua na vingança, mas não deixa de ser nemesicamente castigado. Neste final, subjaz uma fatalidade que o Bardo inglês soube aproveitar da melhor maneira.

Mas, tal como acontece com as vidas de Temístocles e Camilo, que parecem ter sido profundamente influenciadas por um modelo baseado nas figuras épicas de Ulisses e Aquiles, também as biografias de Coriolano e Alcibíades sugerem um dívida assinalável para com um modelo orientado pelas mesmas personagens. Isto é, o carácter de Coriolano parece ter sido igualmente moldado sobre os aspectos marciais e irascíveis do Aquiles épico, de uma forma que acaba por contribuir para a justificação do seu desaire como estadista. Efectivamente, a ira de Coriolano assemelha-se em muito ao amuo do herói homérico. Tal como as virtudes do arquetípico Aquiles são uma desgraça para os seus inimigos, também Coriolano se revela um adversário invencível para os inimigos de Roma e posteriormente para a própria cidade. M.-L. Freyburger chega mesmo a falar de «a cólera de Coriolano», como se fosse a «cólera de Aquiles», e, recentemente, M. Nerdahl usou a expressão «Aquiles Romano» para se referir a Coriolano ${ }^{26}$. Em seu abono, recordemos que Plutarco diz que Márcio era «lesto na corrida» $(2,1)$, adjectivação que recorda o mais famoso epíteto do Aquiles homérico. Ambos

26 Freyburger (2001); Nerdahl (2007) 118; ver também Pelling (1997); Salmon (1930) 97, n. 2. Note-se ainda que, segundo este autor, a Vida de Coriolano parece dever bastante à de Temístocles, dadas as afinidades reconhecidas. 
assumem uma postura de rejeição em relação às suas origens, ambos são soldados inultrapassáveis, ambos são humilhados e desonrados, ambos mantêm uma relação particularmente próxima com as respectivas mães e estas têm um ascendente significativo sobre os filhos, ao ponto de conseguirem neutralizar a ira deles, fazendo com que os temas do Coriolano de Plutarco em parte coincidam com os da Ilíada ${ }^{27}$.

Esta questão redireccionamos para a problemática das relaçóes entre a História e a Literatura, ou melhor, entre a historiografia e a filologia, particularmente pertinentes no âmbito da Antiguidade Clássica. Até que ponto são as informaçóes disponibilizadas pelos historiadores antigos matéria de facto ou matéria ficcional, importada das tradições literárias de modo a enriquecer os campos áridos da História?28

A biografia de Gaio Márcio Coriolano conta ainda com outras figuras que funcionam como auxiliares de recurso para a construção da mensagem do biógrafo. Uma delas é Tulo, o inimigo que acaba por se constituir o aliado de circunstância, ele próprio instrumentalizado para a vingança do protagonista. De certa forma, seguindo a análise que leva em conta

${ }^{27}$ Sobre o estilo homérico na descrição da tomada de Coríolos (8) ou na batalha contra os Anciates (9), ver Nerdahl (2007) 115-116. Salmon (1930) 97 considera ainda possíveis influências da Oresteia, no passo dedicado à votação das tribos (20).

${ }^{28}$ Rodrigues (2007). Naturalmente, não nos ocupamos aqui do paralelo entre Alcibíades e Ulisses, dado que faz parte do âmbito da biografia do primeiro. O tópico é particularmente desenvolvido em Nerdahl (2007) 108-151. Náo esqueçamos que o próprio Plutarco cita a Ilíada nessa biografia, 32, 5-6. 
a influência épica no desenho do perfil de Coriolano, Tulo é uma espécie de Heitor ou de Turno redifinido. As mulheres são vistas como seres particularmente dotados de um extraordinário poder de mediação e de reconciliação, mas também de capacidade de iniciativa e de empreendedorismo, que não raramente surge como a saída de uma situação menos boa. Se Valéria é o medium através do qual o divino intervém para a salvação de Roma, Volúmnia, alter-ego da Tétis homérica, é uma metáfora da própria Urbe ${ }^{29}$. Neste caso, Plutarco segue a tendência geral da sua visão do feminino, de que é particular testemunho o pequeno tratado $A$ coragem das mulheres (242e). O demos romano funciona como o tirano que cai de forma impiedosa sobre Coriolano e o força ao exílio, senão mesmo à morte. Trata-se de um paralelo com o Agamémnon da Ilíada e da forma como este trata Aquiles na epopeia. Apesar do que se lhe possa condenar, na relação entre os Romanos e Coriolano, parece-nos entrever uma certa simpatia para com este, por parte do biógrafo, que se materializa na descrição do desgoverno causado pelo exílio e da sua ausência, que serve para fazer justiça indirecta ao general. Outro povo, os Volscos, funciona como a contrapartida aos Romanos, os inimigos que acolhem o Coriolano exilado, para depois acabarem por eliminá-lo, qual instrumento nemésico.

Podemos considerar ainda como personagem a Fortuna/Tyche, pois é significativo o papel que ela assume na economia desta biografia, como no geral da obra de Plutarco. Na verdade, o autor segue uma prática

${ }^{29}$ Cf. Bonjour (1975). 
comum no período helenístico, que conferia particular relevo àquela que é fundamentalmente uma abstracção ou ideia divinizada, chegando a considerá-la central no curso da História e do processo histórico ${ }^{30}$. A Fortuna/ Tyche, que era então uma crença bastante popular e enraizada, está particularmente presente no romance grego, género que tem diversos pontos de contacto com as biografias plutarquianas ${ }^{31}$. Muitas vezes, é essa divindade a responsável pelo desenvolvimento do enredo nos textos romanescos, chegando a ser confundida com o Destino. Mas a sua expressão traduz-se mais no que entendemos por "acaso» ou "providência» omnipresente, que pode condicionar inexoravelmente a acção, de forma negativa ou positiva para os heróis. Plutarco cita-a cinco vezes nesta biografia, atribuindo-lhe precisamente as funções enunciadas, o que parece ir ao encontro da sua Filosofia da História $(8,5 ; 24,6 ; 32,4 ; 35,2 ; 37,4)^{32}$.

Ainda que o enredo da vida de Gaio Márcio náo seja uma criação plutarquiana, porque pré-existia, a forma dramática e adjectivada como o carácter da personagem é moldado - o homem que se distingue como honesto, detentor das melhores virtudes heróicas, de coragem e de proficiência militar, para quem a glória chega através da bravura e o orgulho é uma qualidade, mas que também evidencia fraquezas ao ser incapaz de controlar as paixóes malignas, o que acabará por levar à sua destruição - é da responsabilidade de Plutarco

30 SWAIN (1989).

${ }^{31}$ De certo modo, a Fortuna romana equivale ao que os Gregos, em especial os do período helenístico, designavam por Tyche.

32 Swain (1989) 292-295. 
e reside aí a sua genialidade ${ }^{33}$. Talvez isso explique também a razão pela qual aqui se ignora a tradição que contava que Coriolano vivera até à velhice, abdicando do dramatismo do seu assassínio ${ }^{34}$.

33 Como nota Nerdahl (2007) 129, «em vez de apresentar Coriolano como um homem de carácter e de substância, como um herói cujos princípios ditam as suas acçóes, assim como Dionísio faz, Plutarco ilustra os actos de um homem cujas emoçôes ditam as acçóes». Esta posição vai ao encontro da que se pode encontrar no tratado Como dominar a ira? (Moralia 452e). O homem que controla a sua ira tem uma vida abençoada; aquele que lhe cede, por muita grandeza que tenha, só alcançará a miséria.

${ }^{34}$ Cf. Tito Lívio, Desde a fundação da cidade 2, 40. 


\section{VIDA DE CoRiolano}


(Página deixada propositadamente em branco) 
1. 1. Da casa patrícia dos Márcios, em Roma, provieram muitos homens ilustres, como o filho da filha de Numa, Anco Márcio, que foi rei depois de Túlio Hostílio ${ }^{1}$ Aos Márcios pertenciam também Públio e Quinto $^{2}$, que abasteceram Roma com água em maior quantidade e em melhor qualidade; e ainda Censorino, a quem o povo romano escolheu para censor por duas vezes $^{3}$. Foi aliás este que, incitado pelo povo, elaborou e apresentou uma lei para que ninguém pudesse exercer aquela magistratura duas vezes. 2. Órfẫo de pai, Gaio Márcio (pois é sobre ele que aqui se escreve) foi educado pela mãe viúva, provando que a orfandade, apesar de ter coisas desagradáveis, não impede que se venha a ser

${ }^{1}$ Anco Márcio foi, segundo a tradição, o quarto rei de Roma. Tito Lívio 1, 32, 2, identifica a filha de Numa Pompílio como Pompília. Numa Pompílio foi, segundo essa mesma tradiçáo, o sucessor de Rómulo e, portanto, o segundo rei de Roma. Túlio Hostílio terá sido um companheiro de Rómulo e o sucessor de Numa. Sobre esta figura, ver Rodrigues (2005), 155-160, e bibliografia aí citada. Como salienta SALmon, (1930) 98, os Marcii eram uma família plebeia e não patrícia.

${ }^{2}$ Quinto Márcio foi pretor urbano de Roma em 144 a.C. Segundo Plínio-o-Velho, História Natural 31, 41; 36, 121, Q. Márcio reparou vários aquedutos e construiu o de Aqua Marcia, em 144 a.C.

${ }^{3}$ Trata-se de Gaio Márcio Rutílio, cônsul em 310 a.C., que se destacou na guerra contra os Samnitas. Márcio Rutílio foi censor em 294 a.C. e em 264 a.C., momento em que fez publicar a lei a que Plutarco aqui se refere e que lhe valeu o cognome de "Censorino", posteriormente adoptado pela gens Marcia. 
um homem virtuoso e que se distinga da maioria, ainda que alguns, mesquinhos, a responsabilizem e culpem pela corrupção, tendo em conta a negligência com que supostamente teráo sido tratados. 3. Este mesmo homem $^{4}$ deu testemunho dos que acreditam que a natureza, ainda que nobre e boa, se for desprovida de educação, produz muitas coisas boas, mas também más, tal como acontece na agricultura, quando um terreno fértil é deixado ao abandono e sem cuidados 5 . 4. Pois se, por um lado, a força e o vigor do seu espírito livre o levaram a grandes iniciativas e nobres acçóes, por outro, a cólera excessiva e a ambição inflexível fizeram dele alguém com quem era difícil lidar e que se mostrava pouco sociável. Ainda que a sua indiferença para com os prazeres, os sofrimentos e as riquezas fosse admirada, chamando-se a isso moderação, justiça e coragem ${ }^{6}$, detestavam a arrogância e ingratidão que ele mostrava nas relaçóes com os seus concidadáos, pois eram

${ }^{4}$ Plutarco refere-se a Gaio Márcio.

${ }^{5}$ Como referimos na introdução, este é um tema platónico $(A$ República 491a-e), que considera que as almas mais bem dotadas se tornam particularmente más quando viciadas pelas educação.

${ }^{6}$ Trata-se de uma alusão a duas das quatro virtudes cardiais, discutidas essencialmente por Platáo (e.g. A República 427e): dikaiosyne (justiça) e andreia (coragem). Quanto à terceira característica referida por Plutarco, enkrateia, que traduzimos por «moderação" mas que pode igualmente significar "auto-domínio», aproxima-se da sophrosyne (temperança) platónica. Recordamos que a enunciação feita por Ésquilo (Sete contra Tebas 610), tida como um dos primeiros esboços de definição das virtudes cardiais, também não é exactamente igual à apresentada por Platão. A sophia (sabedoria), a primeira das virtudes enunciadas no referido passo platónico, náo é aqui incluída por Plutarco. 
próprias de um oligarca ${ }^{7}$. 5. Na verdade, de todas as coisas boas que a benevolência das Musas dispensa aos homens, nenhuma é como a natureza quando cultivada pela razão e pela educação, que assim se submete à moderação e rejeita os excessos. 6. De um modo geral, porém, naqueles tempos, Roma glorificava as virtudes relacionadas com a guerra e com as acções militares. E a prova disso é o facto de eles chamarem «coragem» à «virtude» e o nome que usam para designar a «virtude» ser comum ao que usam para designar «coragem $»^{8}$.

2. 1. Mais apaixonado do que outros pelos desafios bélicos, Márcio manejava as armas desde criança. Acreditava que as armas externas ao corpo de nada valem a quem não preparou nem exercitou a arma com que a natureza o dotou quando nasceu, pelo que ele treinou o seu corpo para todo o tipo de combate. Chegava a ser tão lesto na corrida como invencivelmente pesado, quando agarrava um inimigo e com ele lutava, mantendo-o debaixo de si. 2. Pelo menos, aqueles que rivalizavam com ele em coragem e virtude, sempre que eram derrotados, responsabilizavam a sua inesgotável força física, que não sucumbia a nenhum esforço.

3. 1. Era ainda um jovem quando participou na sua primeira campanha militar. Isso aconteceu na época em que Tarquínio, depois de ter reinado em Roma e de ter sido expulso, quis, na sequência de vários combates

${ }^{7}$ Entenda-se aqui oligarchikos no seu sentido pejorativo.

${ }^{8}$ Andreia e arete em grego; uirtus, em latim. As raízes de andreia e de uirtus relacionam-se com a ideia de "varão» ou «masculino». 
e derrotas, como que jogar os seus últimos dados ${ }^{9}$ A maioria dos Latinos, assim como muitos outros Itálicos, uniram-se então a ele em campanha e tentaram recuperar Roma, não tanto para lhe agradar, mas sobretudo porque tinham medo e uma inveja cada vez maior dos Romanos, a quem pretendiam derrotar. 2. Nessa batalha, que pendeu tanto para um lado como para o outro, Márcio, que por muitas vezes se revelou um lutador vigoroso aos olhos do ditador ${ }^{10}$, viu um soldado romano cair perto de si e não o abandonou. Pelo contrário: pôs-se de pé diante dele, para o defender, lançando-se contra o inimigo e matando-o. 3. Por ter saído vencedor, o general coroou-o entre os primeiros, com uma coroa de folhas de carvalho. Segundo o costume, essa é de facto a coroa que se oferece a quem protege um cidadáo com o escudo. E isso acontece ou porque o carvalho é honrado entre os Arcádios, a quem um oráculo do deus chamou "comedores de bolotas» ${ }^{11}$, ou porque o carvalho é facilmente encontrado em qualquer local em que se faça uma campanha militar, ou ainda porque, sendo a coroa

9 Lúcio Tarquínio-o-Soberbo (séc. VI a.C.) foi, segundo a tradição, o sétimo e último rei de Roma. Sobre esta figura ver Tito Lívio 1, 34-60, bem como Rodrigues (2005) 167-178, e bibliografia aí citada.

${ }^{10}$ Referência a Aulo Postúmio e à batalha do lago Regilo. Postúmio é indicado como dictator para o ano de 499 ou 496 a.C. Efectivamente, a batalha do lago Regilo teria ocorrido em 499 a.C. (Tito Lívio 2, 19-20) ou em 496 a.C. (Dionísio de Halicarnasso, Antiguidades Romanas 6, 4-13). Ver Rodrigues (2005) 193-196.

${ }^{11}$ Referência a Apolo e ao oráculo de Delfos, Heródoto 1, 66; Dionísio de Halicarnasso, Antiguidades Romanas 1, 31. 
de carvalho consagrada a Zeus Polieus ${ }^{12}$, se pensava ser adequada para oferecer a quem salvava um cidadão. 4 . De todas árvores silvestres, o carvalho é a que produz melhores frutos e, das plantadas, é a mais robusta. Dele, extrai-se a bolota para comer e hidromel para beber. E possibilita ainda que a maioria das aves se transforme em alimento, ao fornecer o visco, que assim se transforma numa ferramenta de caça ${ }^{13} .5$. Diz-se que nesta batalha apareceram os Dioscuros ${ }^{14}$. Estes teriam sido vistos no foro ${ }^{15}$, logo a seguir ao combate, com os cavalos que ainda transpiravam, a anunciar a vitória junto à fonte onde hoje se encontra o templo a eles dedicado. Daí que aquele dia vitorioso, nos idos do mês de Julho ${ }^{16}$, seja consagrado aos Dioscuros.

4. 1. Ao que parece, nos homens jovens, quando a fama e as honras chegam cedo, as naturezas pouco ambiciosas secam, porque satisfazem rapidamente a sua sede, tornando-os incapazes. Mas os espíritos sólidos e firmes são estimulados pelas honras e por elas se distinguem, como se uma brisa os despertasse e

${ }^{12}$ Zeus protector da polis. Optámos por manter a forma «Zeus», usada por Plutarco, rejeitando "Júpiter», porque neste passo, ao contrário do que lemos em 24, 3, estamos perante uma reflexão do autor, que era grego, e não perante uma descrição de cenário romano.

${ }^{13} \mathrm{O}$ visco era utilizado na captura de várias aves.

${ }^{14}$ Castor e Pólux, os irmáos de Helena e Clitemnestra. Sobre estes, ver Rodrigues (2005) 193-196.

${ }^{15} \mathrm{O}$ texto grego refere a agora, conceito equivalente ao que traduzimos. Efectivamente, entre os Romanos seria o forum.

${ }^{16}$ Trata-se do dia 15 de Julho. Sobre as festividades em honra dos Dioscuros, ver H.H. Scullard, Festivals and Ceremonies of the Roman Republic, London, 1981, 65-68. 
neles fizesse aparecer aquilo que há de bom. 2. Eles não as vêem como uma recompensa, mas antes como uma garantia do que farão, envergonhando-se de não estar à altura da sua glória e de não a superar com novas façanhas. 3. Era isto o que Márcio sentia, mantendo a honra como seu objectivo. E como ele desejava constantemente novas acçóes, acumulava proezas sobre proezas e acrescentava despojos a despojos, de modo que os seus sucessivos comandantes rivalizavam sempre por ultrapassar os anteriores nos testemunhos honoríficos que lhe outorgavam. 4. Muitas foram então as batalhas e as guerras levadas a cabo pelos Romanos. Mas náo houve uma sequer de que ele regressasse sem uma coroa ou um outro prémio honroso. 5. Enquanto para outros a meta a alcançar era a excelência, para ele a meta era a alegria da mãe. Esta, quando o via coroado ou ouvia os aplausos que lhe dirigiam, abraçava-o e chorava de alegria, o que ele considerava o maior valor e o enchia de felicidade. 6. De facto, segundo dizem, o mesmo confessou Epaminondas ${ }^{17}$, para quem a maior felicidade era o pai e a mãe, ainda vivos, o terem visto comandar e vencer em Leuctras ${ }^{18}$. 7. Mas se aquele teve a alegria de ver ambos os pais rejubilarem com os seus êxitos, Márcio pensava que devia à mãe a gratidão que cabia ao pai. E não se cansava de agradar e honrar

${ }^{17}$ General tebano do século IV a.C., que elevou a cidade de Tebas a potência militar no período que se seguiu à Guerra do Peloponeso.

18 Batalha de Leuctras (371 a.C.), em que os Tebanos, comandados por Epaminondas, derrotaram os Espartanos, acabando com a hegemonia destes na Hélade. 
Volúmnia ${ }^{19}$, tendo-se inclusivamente casado de acordo com os desejos e vontade dela. E continuou a viver em casa da mãe até mesmo quando teve filhos.

5. 1. Ele tinha já atingido grande reputação e valor na cidade, graças à sua excelência, quando o senado ${ }^{20}$, ao defender os ricos, entrou em desacordo com o povo, que se sentia vítima dos usurários. 2. Pois os pequenos proprietários estavam a ser despojados de tudo o que tinham através de vendas, enquanto os que eram completamente pobres eram levados e presos, com os corpos cheios de ferimentos que haviam arranjado nas campanhas pela pátria. A última delas havia sido contra os Sabinos, momento em que os ricos haviam prometido contenção e o senado escolhido o magistrado ${ }^{21}$ Mânio Valério como garantia disso ${ }^{22}$. 3. Mas apesar de terem combatido na batalha com toda a bravura, a vitória

${ }^{19}$ Em outros autores, a mãe de Gaio Márcio Coriolano chama-se Vetúria e não Volúmnia. Cf. Dionísio de Halicarnasso, Antiguidades Romanas 8, 39, 4; Tito Lívio 2, 40, 1; Valério Máximo 5, 2, 1.

${ }^{20}$ Boule no texto grego original.

${ }^{21}$ «Arconte» no texto grego original. Provavelmente, refere-se a "cônsul», apesar de o termo «arconte» poder designar simplesmente um qualquer magistrado, em sentido geral.

22 Há alguns problemas em torno da identificação desta personagem. Algumas fontes designam-no como "Márcio», enquanto outras referem-se-lhe como «Mânio» e outras ainda como "Marco». A maioria dos editores seguiu Dionísio de Halicarnasso, Antiguidades Romanas 6, 23 e 29, e corrigiu o manuscrito plutarquiano (onde se lê «Márcio») para «Mânio». Mas as dúvidas persistem. Ainda segundo Dionísio de Halicarnasso (6, 39-41), Mânio Valério, que era já idoso e favorável à plebe, foi então designado ditador, uma vez que a situação exigia moderação que evitasse novos focos de revolta. 
sobre os inimigos não originou nenhuma razoabilidade por parte dos usurários, além de que também o senado fingiu não se lembrar do que tinha acordado. Em vez disso, continuava a desconsiderar e a espoliar, pelo que ocorreram desordens e graves tumultos na cidade. Os distúrbios do povo náo passaram despercebidos aos inimigos, que se lançaram contra o país, incendiando-o. Os magistrados convocaram os que estavam em idade militar, mas ninguém obedeceu, pelo que as opinióes dos dirigentes estavam de novo divididas. 4. Alguns pensavam que se devia fazer concessóes aos pobres e suavizar a excessiva austeridade da lei; outros opunham-se a isso. Entre estes estava Márcio, que não dava grande valor ao dinheiro e que considerava que, se houvesse prudência, se deveria acabar e pôr fim ao que entendia ser um princípio e tentativa de insolência e audácia da multidão, ao revoltar-se contra as leis.

6. 1. Por causa desta questão, foram muitas as vezes que, em pouco tempo, o senado se reuniu, mas ninguém propôs uma solução definitiva. Entretanto, os pobres juntaram-se e, encorajando-se mutuamente, abandonaram a cidade. Ocuparam o monte hoje conhecido como Sagrado, junto ao rio Ânio ${ }^{23}$, e aí se instalaram sem qualquer violência ou provocação.

${ }^{23}$ Afluente do Tibre. A secessão da plebe, um dos acontecimentos mais importantes no processo de afirmação da República Romana, ocorreu em 494 a.C. Segundo Tito Lívio 2, 32, 2, o Monte Sagrado localizava-se a três milhas de Roma. Uma outra tradiçấo, igualmente referida por Tito Lívio 2, 32, afirmava que a retirada da plebe se fizera no Monte Aventino. 
Apenas proclamavam que havia já tempo que tinham sido expulsos da cidade pelos ricos, que a Itália lhes providenciaria em qualquer lado ar puro, água e um sítio onde ser enterrados, pois era também isso tudo o que tinham quando viviam em Roma, mas que pelo menos não seriam feridos nem morreriam a combater pelos ricos. 2. Isto alarmou o senado que, de entre os seus anciáos, enviou ao povo os que considerava mais justos. 3. O porta-voz foi Menénio Agripa ${ }^{24}$, que, com súplicas ao povo e um discurso sincero a favor do senado, disse umas palavras quando terminava, que se transformaram numa fábula ${ }^{25}$ de tão recordadas que têm sido: 4. Afirmou então: "Os membros de um homem rebelaram-se todos contra o estômago, acusando-o de ser o único que no corpo nada fazia e que com nada contribuía, permanecendo apenas ali sentado, enquanto os outros sofriam grandes penas e trabalhos para o manter vivo. $\mathrm{O}$ estômago riu-se daquela ingenuidade, pois eles não percebiam que ele recebia o alimento e o reenviava depois para todas as outras partes, redistribuindo-o $»^{26}$. 5. «Pois bem», comentou ainda, «o mesmo vos diz o senado, ó cidadãos. De facto, as resoluçóes e decisões que ali se tomam devem ser cuidadosamente administradas e distribuídas para benefício de todos vós».

${ }^{24}$ Menénio Agripa foi cônsul em 503 a.C., ano em que saiu vitorioso sobre os Sabinos. Cícero, Bruto 54, afirma que quem pronunciou este discurso foi M. Valério.

${ }^{25}$ A palavra usada por Plutarco é mythos, que aqui traduzimos por «fábula».

${ }^{26}$ Trata-se de um apólogo que pode ser igualmente lido em Tito Lívio 2, 32, 8-12. 
7. 1. Depois disto, reconciliaram-se e pediram ao senado que fossem escolhidos cinco homens para defensores dos que necessitavam de ajuda. Foi o que aconteceu e esses chamam-se agora «tribunos da plebe» ${ }^{27}$. 2. Os primeiros a ser eleitos foram os próprios chefes da revolta: Júnio Bruto e Veluto Sicínio ${ }^{28}$. 3. Assim que a cidade voltou a estar unida, foram muitos os que tomaram de imediato as armas e se colocaram às ordens dos chefes, prontos para a guerra. 4. Márcio, a quem não agradava a força que o povo ganhava por concessão da aristocracia e ao ver o mesmo sentimento em muitos outros patrícios, apelava para que não cedessem ao povo nos combates pela pátria, mas que se mostrassem diferentes, pela superioridade em virtude e não em poder.

8. 1. Entre o povo dos Volscos, contra o qual estavam em guerra, a cidade dos Coriolanos era a que maior reputação tinha. $\mathrm{O}$ cônsul Comínio ${ }^{29}$ tinha-a cercado e os restantes Volscos, alarmados, vieram de todo o lado e juntaram-se para a ajudar contra os Romanos. Vinham para combater em frente à cidade e atacá-los em duas frentes. 2. Comínio dividiu as suas forças e enquanto

27 Sobre esta magistratura, ver J. Gaudemet, Les institutions de l'Antiquité, Paris, 20027, 150-152.

${ }^{28}$ Os nomes dos cinco tribunos podem ser lidos em Dionísio de Halicarnasso, Antiguidades Romanas 6, 89. Mas as fontes variam nesta identificação.

${ }^{29}$ Trata-se de Póstumo Comínio, que foi cônsul pela primeira vez em 501 a.C. e pela segunda em 493 a.C. O assédio de Coríolos ocorreu precisamente nesse ano de 493 a.C., quando Comínio partilhou o consulado com Espúrio Cássio. 
enfrentava pessoalmente os Volscos que atacavam do lado de fora, Tito Lárcio ${ }^{30}$, um dos melhores Romanos, assediava a cidade. Os Coriolanos menosprezaram os que ali ficaram e avançaram contra eles. No primeiro assalto, dominaram e perseguiram os Romanos até à paliçada. 3. Mas aí, Márcio saiu com uns poucos e derrubou muitos dos que se aproximavam, resistindo às investidas dos restantes. Aos gritos, incitou os Romanos, pois, tal como Catão ${ }^{31}$, pensava que um soldado devia ser temível não apenas pela força golpeante do braço, mas também pela voz e pelo aspecto do rosto, que deviam ser terríveis para o inimigo que o defrontasse. Foram muitos os que o seguiram, juntando-se a ele. Assustados, os inimigos fugiram. 4. Mas, não se contentando, ele perseguiu-os, obrigando-os a combater, mesmo enquanto fugiam em direcção às portas da cidade. 5 . Aí, ao ver que os Romanos desistiam da perseguição, tantos eram os dardos que lhes lançavam da muralha, e como ninguém tinha coragem de perseguir os fugitivos até uma cidade cheia de inimigos armados, ele parou e, encorajando-os, começou a chamá-los e a gritar que a Fortuna $^{32}$ abre mais depressa a cidade aos perseguidores do que aos fugitivos. 6. Mas não foram muitos os que lhe deram ouvidos, pelo que ele forçou o caminho por

${ }^{30}$ Segundo Tito Lívio 2, 18, 1-5, este foi o primeiro ditador de Roma, em 498 a.C. Foi ainda cônsul em 501 a.C. e prefeito da cidade em 494 a.C. Tito Lárcio fez ainda parte da embaixada que em 493 a.C. tentou convencer os plebeus à reuniáo.

31 Referência a Marco Pórcio Catão ou Catão-o-Censor. A mesma ideia é retomada pelo próprio Plutarco na biografia de Catão; ver Plutarco, Catão Maior 1, 8.

${ }^{32}$ Tyche. 
entre os inimigos, avançando portas adentro, sem que ninguém tivesse coragem para lhes resistir. Mas assim que perceberam que eram muito poucos os que estavam lá dentro, reagruparam-se e combateram-nos. Diz-se que ele combateu de forma incrível dentro da cidade, entre amigos e inimigos, evidenciandose tanto pelas façanhas dos seus braços, como pela agilidade dos seus pés, como pela audácia do seu espírito. Venceu todos quantos enfrentou, empurrando uns para os lugares mais distantes, enquanto outros se rendiam, depondo as armas. Deu assim a Lárcio a oportunidade para que os Romanos penetrassem na cidade ${ }^{33}$.

9. 1. A cidade foi assim tomada e a maioria ocupou-se do saque e da pilhagem de riquezas. Então, Márcio gritou indignado que era ofensivo que enquanto o cônsul e os seus concidadãos provavelmente caíam e lutavam contra os inimigos, eles se preocupavam em enriquecer ou que sob o pretexto do enriquecimento fugiam do perigo. 2. Não foram muitos os que fizeram caso, mas ele levou consigo os voluntários e seguiu pelo caminho que percebeu ser aquele pelo qual o exército avançara. A maior parte das vezes, exortava e convidava os que o seguiam a não desistirem. Outras vezes, orava aos deuses para que não o abandonassem em combate, pois chegara a oportunidade de partilhar o perigo com os seus concidadáos. 3. Naquele tempo, os Romanos tinham o costume de, quando alinhados e prestes a tomar

33 A tomada de Coríolos é igualmente narrada em Dionísio de Halicarnasso, Antiguidades Romanas 6, 92, 3, e em Tito Lívio 2, 33, 5. 
os escudos depois de cingir a toga ${ }^{34}$, pronunciar um testamento que náo era registado e em que nomeavam o seu herdeiro aos três ou quatro que os ouvissem ${ }^{35}$. 4. Era nisso que os soldados estavam, quando Márcio se reuniu a eles, à frente dos inimigos. 5. Ao princípio, alguns ficaram perturbados ao vê-lo na companhia de poucos e coberto de sangue e suor. Mas quando, correndo em direcção ao cônsul, Márcio alegremente lhe estendeu a mão direita e comunicou a captura da cidade, Comínio beijou-o e apertou-o entre os braços. Então, ao ficarem a saber do êxito, ou adivinhando-o, os soldados romanos encheram-se de coragem e, gritando, pediram-lhe que os conduzisse ao combate. 6. Márcio perguntou a Comínio como estava organizado o exército do inimigo e onde se posicionavam as forças. Ele disse-lhe que suspeitava de que as coortes do meio eram as dos Anciates ${ }^{36}$, os mais aguerridos e mais orgulhosos de todos. Márcio disse entáo: "Nesse caso, exijo e suplico-te mesmo que nos coloques em frente a esses homens.» $\mathrm{O}$ cônsul fez-lhe a vontade, maravilhado com o seu zelo. 7. Assim que a carga de lanças começou, Márcio lançou-se contra as primeiras fileiras dos Volscos. Os que aí estavam

${ }^{34} \mathrm{O}$ termo grego é tebenna, que significa «manto» ou «capa». Este termo tem sido entendido, todavia, como o equivalente latino de toga ou de trabea.

35 Trata-se do testamentum in procinctu, referido por Gaio, Instituiçóes 2, 101; 103; Cícero, Do orador 1, 228; Da natureza dos deuses 2, 9; Aulo Gélio 15, 27, 3; Veleio Patérculo 2, 5, 3. Esta forma testamentária era feita perante o exército disposto para o combate e com a toga «arregaçada», sendo que o exército substituía aqui a assembleia do povo. Ver M. Kaser, Römisches Privatrecht, München, 1992, 346.

${ }^{36}$ Os habitantes de Âncio, cidade do Lácio. 
não asseguraram a sua posição na falange, que ficou imediatamente partida em dois. De cada um dos lados, viraram-se contra ele, cercando-o com as armas, pelo que o cônsul se inquietou e enviou-lhe os mais bravos dos seus homens. 8. Deu-se entáo um combate feroz à volta de Márcio e foram muitos os que, em pouco tempo, caíram mortos. Mas acossando e pressionando com toda a força, eles derrotaram os inimigos. Quando se voltavam para persegui-los, pediram a Márcio, abalado pelo cansaço e pelas feridas, que regressasse ao campo. 9. Mas ele respondeu que o cansaço não era atributo dos vencedores e perseguiu os fugitivos. $\mathrm{O}$ resto do exército foi derrotado, havendo muitos mortos e muitos prisioneiros.

10. 1. No dia seguinte, o cônsul, com Lárcio e os outros reunidos ao seu lado, subiu à tribuna e, depois de dar as devidas graças aos deuses por táo grandes êxitos, voltou-se para Márcio. 2. Começou por fazer um admirável elogio, tanto pelo combate de que fora espectador, como pelos testemunhados por Lárcio. 3. Depois, das muitas riquezas que tinham angariado, como armas, cavalos e homens, ordenou-lhe que tomasse para si um décimo de cada, antes de distribuir pelos restantes. Além disso, pela sua coragem, presenteou-o com um cavalo equipado. 4. Márcio avançou por entre a aprovação dos Romanos e disse que recebia o cavalo e que agradecia os elogios do magistrado, mas que dispensava o que acreditava ser um pagamento e não uma honra, e que se contentaria com a sua parte, 
tal como cada um dos restantes. «Mas peço um favor especial», disse, «e suplico para que mo concedam. 5. Entre os Volscos havia um hóspede que era meu amigo, um homem justo e sensato. Ele é agora um prisioneiro e, antes rico e feliz, é agora um servo. Dos muitos males que agora o afligem, bastar-me-ia evitar-lhe um: o de ser vendido.» 6. Depois de dizer isto, ouviu-se uma impressionante aclamação e foram mais os homens que admiraram o desprendimento de Márcio em relação às riquezas do que a sua bravura na guerra. 7 . E até os que sentiam inveja e ciúmes dele por ter sido distinguido com tais honras o acharam digno de as receber, precisamente por as ter rejeitado, e apreciavam mais a virtude que o fazia desprezar tâo grande gratificação do que a que o fazia dela merecedor. 8. Pois o bom uso das riquezas é melhor do que o das armas, mas mais nobre do que usar as riquezas é não cobiçá-las.

11. 1. Quando a multidão parou de aclamar e aplaudir, Comínio retomou a palavra e disse: "Concidadãos, não podeis obrigar este homem a aceitar estes presentes se ele não quer recebê-los. Mas ofereçamos-lhe algo que náo pode recusar. Votemos e concedamoslhe o uso do nome "Coriolano", se é que as suas acçôes não lho outorgaram já, antes de nós.» 2. Daqui veio o seu terceiro nome, Coriolano. Fica assim evidente que «Gaio» era o seu nome próprio ${ }^{37}$, enquanto "Márcio» era o da origem comum da sua

${ }^{37} \mathrm{O}$ praenomen. 
casa $^{38}$. O terceiro nome era usado depois de adicionado, na sequência de uma acção, de um acontecimento, de uma forma física ou de uma virtude ${ }^{39}$. Os Gregos punham um sobrenome no seguimento de uma façanha, como «Sóter» e "Calínico»" ${ }^{40}$; de uma forma física, como "Físcon» e "Gripo" ${ }^{41}$; de uma virtude, como "Evérgeta» e "Filadelfo»" ${ }^{42}$; ou de um êxito, como "Eudémon» ${ }^{43}$, que era o segundo nome de Bato $\mathrm{II}^{44}$. 3. A alguns reis deram apelidos ridículos, como «Dóson» ${ }^{45}$ a Antígono e "Látiro» ${ }^{46}$ a Ptolemeu. 4. Este tipo de nomes, porém, foi mais usado pelos Romanos, que chamaram "Diadémato» ${ }^{47}$ a um dos Metelos, porque, devido a uma ferida, teve de andar muito tempo com uma faixa na testa ${ }^{48}$. E a outro chamaram "Célere»" ${ }^{49}$, porque organizou jogos de gladiadores poucos dias depois da morte do pai, deixando todos

${ }^{38} \mathrm{O}$ nomen ou nome gentílico.

${ }^{39}$ Refere-se ao cognomen.

40 «Salvador» e "O da bela vitória». Cognomes dados a Ptolemeu I e a Seleuco II.

${ }^{41}$ «Pançudo» e "O de nariz aquilino». Cognomes dados a Ptolemeu VIII e a Antíoco VIII.

42 «Benfeitor» e «Amigo do irmão». Cognomes dados a Ptolemeu III e a Ptolemeu II.

43 «Feliz».

${ }_{44}$ Trata-se de um rei de Cirene.

45 "O que vai dar», em referência a Antígono da Macedónia. Cf. Plutarco, Paulo Emílio 8, 3.

${ }^{46}$ "Chícharo» ou «grão-de-bico», em referência a Ptolemeu X. Cf. o latim cicer.

47 «O que usa diadema».

48 Trata-se de Lúcio Cecílio Metelo, que foi pretor em 120 a.C. e cônsul em 117 a.C.

49 «Rápido», em referência a Quinto Cecílio Metelo Célere, cônsul em 60 a.C. 
admirados com a rapidez e eficácia em prepará-los. 5 . Hoje em dia, porém, alguns devem o seu nome a algo ocorrido durante o seu nascimento. Assim acontece com «Próculo»" se é dado à luz quando o pai está longe de casa; e com "Póstumo»" se nasce depois da morte do pai; e se for um gémeo que sobrevive à morte do outro, chama-se "Vopisco»" ${ }^{52}$ 6. Por causa de pormenores físicos dão-se não apenas os nomes de "Sula» ${ }^{53}$, "Nigro» ${ }^{54}$, "Rufo» ${ }^{55}$, como também "Ceco» ${ }^{56} \mathrm{e}$ "Clódio» ${ }^{57}$. Isto é uma boa prática, pois acostuma as pessoas a náo pensar como vergonha ou insulto a cegueira ou outra infelicidade física, mas antes a responder a estes nomes como de família. Mas deixemos este assunto, mais adequado a outro lugar ${ }^{58}$.

12. 1. Mal tinha acabado a guerra, já os cabecilhas do povo voltavam a suscitar as dissensôes, sem qualquer nova razão nem qualquer queixa justificada. Tomaram como pretexto contra os patrícios os males que necessariamente se seguiram aos conflitos e distúrbios anteriores. 2. Com efeito, a maior parte da terra tinha

${ }^{50}$ Nome que deriva do advérbio latino procul, «longe».

${ }^{51}$ Nome que deriva do adjectivo latino postumus, "posterior».

52 Do latim uopiscus, "Aquele que sobrevive» ao irmáo gémeo.

53 «Vermelho», de acordo com Plutarco, Sula 2, 2.

54 «Negro».

55 "Vermelho".

56 "Cego".

57 "Coxo".

58 Como notam Pérez Jiménez (2006), 80, n. 39, o interesse pelos nomes romanos levou Plutarco a escrever um tratado hoje perdido (Acerca dos três nomes). Ver ainda Plutarco, Mário 1, 1. 
deixado de ser cultivada e semeada. E, devido à guerra, não se havia providenciado a importação de víveres. 3 . Acabaram por surgir, portanto, grandes dificuldades e quando os tribunos da plebe viram que não havia provisóes no mercado e que, se as houvesse, o povo não teria meios para adquiri-las, começaram a fazer acusaçóes contra os ricos, a quem culpavam de ter provocado a fome por vingança. 4. Foi entáo que chegou uma embaixada de Veliternos ${ }^{59}$, que lhes ofereceu a sua cidade e pediu que enviassem para lá colonos, pois sobreviera uma peste que provocara uma tal ruína e destruição entre os homens, que sobrara apenas um décimo de todos eles. 5. Os mais sensatos pensaram que o pedido dos Veliternos era bem oportuno, uma vez que, devido à carestia, necessitavam de ajuda, ao mesmo tempo que alimentavam a esperança de acabar com a dissenção, através da purga dos mais turbulentos e dos que mais se agitavam com a influência dos demagogos da cidade, como se fossem uma excreção maligna. 6. Foram precisamente estes que os cônsules registaram com a intenção de enviá-los para a colónia e ordenaram aos outros que fizessem uma campanha contra os Volscos. O seu objectivo era fazer com que faltasse tempo para revoltas e confusóes. Eles acreditavam que, ao estarem de novo juntos nas armas e no acampamento, tanto ricos e pobres como plebeus e patrícios se mostrariam mais mansos e tolerantes uns para com os outros.

${ }^{59}$ Velitras era uma cidade latina, localizada ao norte da região dos Volscos. 
13. 1. Os cabecilhas do povo ${ }^{60}$, Sicínio e Bruto, opuseram-se a esta decisão, gritando que se suavizava um acto cruel ao chamar colónia àquele lugar, enquanto os pobres eram condenados à ruína, ao serem enviados para uma cidade onde o ar era impuro e que estava repleta de cadáveres insepultos, forçando-os a viver com uma divindade $^{61}$ hostil e abominável. 2. Pois, como se não bastasse alguns dos cidadãos morrerem à fome e outros serem expostos à peste, desencadeavam voluntariamente uma guerra, para que deste modo nenhum mal faltasse à cidade que se recusara a ser serva dos ricos. 3. Farto de ouvir estas palavras, o povo náo se apresentou aos cônsules para o registo, e recusou o envio para a colónia. 4. A polémica instalou-se então no senado. Márcio, que por esta altura se sentia orgulhoso e se achava importante por ser admirado pelos poderosos, decidiu publicamente ficar à frente da oposição aos chefes populares. 5. Os sorteados foram então obrigados a ir para a colónia, sob a ameaça de grandes castigos. Mas como todos se recusavam a ir, o próprio Márcio reuniu os seus clientes, e todos os que conseguiu convencer, e fez uma incursão na terra dos Anciates. 6. Aí, encontrou muito trigo e reuniu um grande saque de gado e de cativos. Mas não tomou nada para si próprio. Juntou-se aos companheiros de expedição e regressaram a Roma, levando com eles um grande saque. Perante isto, os outros

${ }^{60}$ No texto grego original, Plutarco chama-lhes «demagogos», o que deve aqui ser entendido como «os que chefiavam o povo». Trata-se, evidentemente, dos tribunos da plebe mencionados no parágrafo 7 .

${ }^{61}$ No texto grego original, Plutarco usa o termo daimon, que pode significar igualmente um "génio» ou um «espírito». 
arrependeram-se da sua decisão e invejaram as riquezas acumuladas, hostilizando Márcio, cuja glória e poder não suportavam, pois, segundo diziam, aumentavam em prejuízo do povo.

14. 1. Pouco tempo depois, Márcio disputou o consulado. A multidão acalmou-se e o povo sentiu vergonha por desonrar um homem que era um príncipe em linhagem e virtude e por humilhá-lo, depois de tantas e tão grandes acçóes. 2. Era hábito, entre os que disputavam as magistraturas, envergar a toga ${ }^{62}$ sem a túnica ${ }^{63}$ e ir ao foro ${ }^{64}$ apelar e saudar os cidadáos. Com tamanha simplicidade sugeria-se humildade mas também se mostravam as cicatrizes, que eram sinal de coragem. 3. Pois, certamente, não era a suspeição de distribuição de dinheiro e de suborno a razão pela qual queriam que se apresentassem aos cidadãos sem túnica e sem cinturáo quando lhes vinham pedir [o voto]. De facto, foi muito mais tarde, muito tempo depois, quando começou a compra e venda de votos, que o dinheiro ganhou importância nas assembleias de votantes. 4. A partir de então, a corrupção atingiu os tribunais e os acampamentos e transformou a cidade numa monarquia, subordinando as armas ao dinheiro. 5. Náo estava errado aquele que disse que o primeiro a destruir o povo foi também o primeiro que lhe ofereceu banquetes e subornos. Em Roma, este mal apareceu de forma subtil, em segredo e aos poucos, e náo às claras e de rompante. 6. Na verdade, desconhecemos quem foi o primeiro em Roma a subornar o povo ou os tribunais;

${ }^{62} \mathrm{O}$ termo grego usado é himation.

${ }^{63} \mathrm{O}$ termo grego usado é chiton, i.e., a veste interior.

${ }^{64}$ Agora, no texto grego original. 
em contrapartida, em Atenas, diz-se que o primeiro a dar dinheiro aos juízes foi Ânito, o filho de Antémion, quando foi levado a julgamento por traição, na questão de Pilo ${ }^{65}$, no fim da Guerra do Peloponeso, época áurea em que a geração incorrupta ainda ocupava o foro de Roma.

15. 1. Márcio, porém, tinha muitas feridas, dos muitos combates em batalhas que protagonizou durante dezassete anos seguidos ${ }^{66}$, pelo que os outros respeitaram o seu valor e escolheram-no. 2. Chegado o dia da votaçáo, Márcio apareceu triunfante no foro, acompanhado pelo senado. Todos os patrícios à sua volta mostravam por ele um interesse como nunca haviam manifestado antes por ninguém, pelo que a multidáo deixou de mostrar a sua boa-vontade para com ele, deixando vir ao de cima o ressentimento e a inveja. 3. A estes sentimentos somava-se o do medo de o poder ficar na posse de um aristocrata com tanta reputaçáo entre os patrícios, pois poderia subtrair liberdade ao povo. Com isto em mente, recusaram-se a eleger Márcio. 4. Assim, foram outros

${ }^{65}$ Cidade localizada na costa ocidental do Peloponeso, na Messénia. Pilo foi o cenário de uma grave derrota infligida pelos Atenienses aos Espartanos, aquando da Guerra do Peloponeso, em 425 a.C. Esta vitória deu aos Atenienses uma posição avançada permanente em território inimigo. Esparta viu-se por isso obrigada a abandonar as suas incursóes na Ática e a encetar as negociaçóes de paz. Os Atenienses mantiveram a sua posição em Pilo até 409 a.C. Ânito foi o principal acusador de Sócrates em 399 a.C. Anos antes, em 409 a.C., fora enviado a Pilo como estratego. Cf. Aristóteles, Política 27, 5; Plutarco, Alcibiades 4, 6.

66 Esta referência temporal tem sido considerada um erro de Plutarco, que terá interpretado mal o passo de Dionísio de Halicarnasso, Antiguidades Romanas 7, 1, 5. Ver Pérez Jiménez (2006), 85, n. 57. 
os designados ${ }^{67}$, o que atingiu o senado em cheio, pois pareceu-lhe uma afronta feita mais a si próprio do que a Márcio. E este não se conteve nem se resignou, pois na maioria das vezes vivia sob a paixão e o ímpeto da alma, afirmando que era aí que estava a grandeza e o orgulho. Mas faltava-lhe a determinação e a doçura, de que é composta a maior parte da virtude política e que crescem com a razão e a educação. E também desconhecia que a arrogância, que segundo diz Platão é uma aliada da solidão ${ }^{68}$, deve ser de facto evitada por quem se dedica a assuntos públicos e por quem lida com pessoas, e que deve ser ainda um amante da resignação, da qual alguns tantas vezes troçam. 5. Mas como ele era sempre rude e obstinado e como pensava que vencer e dominar toda a gente em todo o lado era uma prova de coragem e náo de fraqueza e de brandura, que por causa da dor e do sofrimento da alma levam à tumefacção da ira, retirou-se muito agitado e amargurado com o povo. 6. Então, os jovens patrícios em idade militar, que na cidade eram os mais orgulhosos da sua nobreza e os mais prósperos e que sempre o rodearam com uma atenção extraordinária, acompanharam-no e ficaram junto dele. Mas não foi para o seu bem, pois ao partilhar com ele o sofrimento e a humilhação, só lhe inflamaram a ira. 7 . É que, para eles, ele era o comandante e o mestre afável da arte da guerra nas campanhas militares e promovia a

${ }^{67}$ Os cônsules daquele ano foram M. Minúcio Augurino e A. Semprónio Atratino. Ver Pérez Jiménez (2006), 86, n. 59. Também segundo Apiano, História Romana 1, frg. 2, a plebe não votou em Márcio para o consulado por temer a sua arrogância.

${ }^{68}$ Cf. Platão, Cartas 321c, dirigida a Díon. 
virtude entre eles, sem invejas, tornando-os orgulhosos dos seus êxitos ${ }^{69}$.

16. 1. Nisto, chegou trigo a Roma. Muito dele fora comprado em Itália, mas não era menos o oferecido por Siracusa, enviado pelo tirano Gélon ${ }^{70}$, pelo que a maioria ficou com grandes esperanças. Esperava que a cidade se livrasse ao mesmo tempo da escassez e das dissensóes. 2. Então, o senado reuniu-se e o povo concentrou-se no exterior, à espera do desenlace. Esperava ser favorecido no mercado e que as ofertas fossem distribuídas gratuitamente. 3. Lá dentro estavam os que persuadiam o senado a fazê-lo. 4. Mas Márcio levantou-se e atacou severamente os que favoreciam a multidão, chamando-lhes demagogos e traidores da aristocracia, por alimentarem, contra si próprios, as sementes malignas de insolência e de soberba que haviam sido lançadas entre o populacho, quando nobre seria evitar o começo do seu crescimento e náo fortalecer o povo, ao dar-lhe táo grande poder ${ }^{71}$. Mas o povo era já temido, pois tudo se fazia segundo a sua vontade e a nada sendo obrigado se não o desejasse, e

${ }^{69}$ Existem lacunas neste último período que confundem o leitor, pelo que, com a maioria dos filólogos, traduzimos pelo sentido que a frase parece ter.

${ }^{70} \mathrm{Na}$ verdade, Gélon foi tirano de Gela, entre 491 e 485 a.C., e de Siracusa entre 485 e 478 a.C., pelo que esta doação deverá ter ocorrido enquanto Gélon governava em Gela e não em Siracusa.

${ }^{71}$ Como foi já notado, por outros autores, há aqui um jogo de palavras, conseguido pelo uso de en archei («no começo») e archei ("poder») na mesma frase. Plutarco refere-se ao poder do tribunato da plebe, criado na sequência da secessão de 494 a.C. 
nem sequer obedecia aos cônsules. Antes pelo contrário: envolto numa anarquia, chamava magistrados aos seus próprios cabecilhas. 5. E disse ainda: «Sentarmo-nos para votarmos doaçóes e distribuiçóes, tal como fazem os Gregos ${ }^{72}$ mais democratas, é com certeza promover a desobediência para a nossa ruína comum ${ }^{73}$. 6. Pois é certo que não dirão que recebem tudo isso como gratificação pela expedição em que não participaram, pelas revoltas que causaram traindo a sua pátria, e pelas falsas acusaçóes contra o senado a que deram crédito. Antes pelo contrário. Convencidos de que concordamos em dar-lhes tudo isso porque temos medo e porque queremos adulá-los, não terão limites para a desobediência e não cessarão as dissençóes e as revoltas. 7. Isto é, portanto, simplesmente uma loucura. Se formos sensatos, acabaremos com o seu tribunato, que corrói o consulado e divide a cidade, que já não é apenas uma como costumava ser, mas que se dividiu de tal modo que não voltaremos a estar em harmonia e em comunhão, como não acabaremos de fazer mal uns aos outros, lançando mutuamente a discórdia entre nós.» ${ }^{74}$

17. 1. Foi extraordinário como, ao dizer estas coisas, Márcio conseguiu que os jovens e quase todos os

${ }^{72}$ No texto original grego, lemos, como seria de esperar, "Helenos». Mas o mais natural para um romano seria chamar-lhes «Gregos», pelo que optámos por esta traduçáo.

${ }^{73}$ Esta é uma referência à prática ateniense de distribuir os rendimentos das minas de Láurion. Ver Pérez Jiménez (2006), 89, n. 68.

74 Cf. Tito Lívio 2, 34, 8-11, e Dionísio de Halicarnasso, Antiguidades Romanas 7, 21, 2. 
ricos partilhassem do entusiasmo, gritando que aquele era o único homem da cidade que era inconquistável e que não aceitava adulaçóes. 2. Mas, ao preverem o que ia acontecer, alguns dos anciáos opuseram-se. E o resultado não foi bom. 3. Defacto, os tribunos da plebe ali presentes perceberam que Márcio ia ganhar com a sua moção, pelo que saíram a correr por entre a multidão, gritando e incitando a que se associassem a eles e os ajudassem. 4. Realizou-se então uma tumultuosa assembleia, onde se repetiram em público as palavras proferidas por Márcio. Pouco faltou para que o povo, indignado, caísse sobre o senado. Os tribunos da plebe culparam Márcio e mandaram chamá-lo para que falasse em sua defesa ${ }^{75}$. 5. Mas ele foi violento e expulsou os enviados. Estes fizeram-se então acompanhar dos edis, com o objectivo de levar o homem à força, arrastando o seu corpo. 6. Os patrícios, porém, juntaram-se, derrubaram os tribunos da plebe e bateram nos edis. 7. Quando caiu a tarde, os distúrbios cessaram. Mas assim que amanheceu, ao verem que o povo corria desalmadamente de todos os lados em direcçáo ao foro, os cônsules temeram pela cidade. Convocaram uma reuniáo do senado, para considerar a possibilidade de acalmar e apaziguar a multidão através de palavras e ponderação, pois tinham de ser sensatos e perceber que aquele não era o momento para rivalidades nem para disputas de honra, uma vez

$75 \mathrm{O}$ episódio aqui relatado sugere tratar-se de um caso de coercendi potestas, i.e., o poder que os tribunos da plebe tinham de iniciar um processo a um membro da aristocracia. Este poder, todavia, só é conhecido a partir do século III a.C. Ver R.M. Ogilvie, A Commentary on Livy. Books 1-5, Oxford, 1978, 323-326. 
que a situação era perigosa e grave e exigia uma política prudente e ponderada. 8. A maioria concordou, pelo que foram logo falar com o povo o melhor que podiam, apaziguando-o e neutralizando as acusaçóes caluniosas, moderando as admoestaçóes e refreando as censuras, e garantindo que, em relação ao valor dos bens e das provisóes, não haveria mais querelas entre eles.

18. 1. Assim que a maior parte do povo anuiu, tornou-se evidente que, pela forma ordenada e tranquila com que escutava aquelas palavras, se estava a deixar levar. Os tribunos levantaram-se e disseram que, uma vez que o senado mostrava sensatez, o povo cederia em tudo o que fosse justo. Mas exortaram Márcio a falar em sua defesa relativamente ao seguinte: podia ele afirmar que não desejava a ruína da constituição e a desunião do povo, ao incitar o senado a desobedecer ao seu apelo e, no fim de tudo, ao promover a guerra civil, por bater nos edis e tratá-los de forma ultrajante no foro e por levar os cidadãos a pegar em armas? 2. Ao afirmarem isto, ou queriam humilhar Márcio publicamente (caso ele fosse levado pelo medo a reverenciar a multidão, o que seria contrário à sua natureza) ou a virar a ira do povo contra ele (caso ele agisse de acordo com a sua natureza, mantivesse o seu orgulho e revelasse o seu carácter). Era precisamente isto que esperavam, pois tinham avaliado o homem correctamente. 3. Então, ele pôs-se de pé para falar em sua defesa e o povo manteve o silêncio e a calma. Mas quando, perante homens que esperavam palavras de súplica, começou não apenas a falar com uma franqueza 
insuportável como também a acusá-los mais do que a defender-se e ainda a mostrar, pelo tom da voz e pela fisionomia do rosto, uma total ausência de medo que resvalava o desdém e o desprezo, o povo exasperou-se e tornou-se visível a indignação e o desagrado que o discurso lhe causava. Foi então que Sicínio, o mais corajoso dos tribunos da plebe, depois de ter conversado um pouco com os colegas, avançou para o centro e proclamou que Márcio era condenado à morte pelos tribunos da plebe, ordenando aos edis que o conduzissem pois ao topo da cidadela e o empurrassem pela ravina abaixo ${ }^{76}$. 4. Mas quando os edis puseram as máos sobre o corpo dele, houve muitos, incluindo plebeus, que pensaram que ali estava a acontecer algo de terrível e de excessivo e os patrícios, completamente fora de si e indignados, acorreram aos gritos a soltá-lo. Uns mantinham afastados com as mãos os que queriam apanhá-lo, formando um círculo para proteger Márcio. 5. Outros estendiam as mãos como que suplicando para a multidão, uma vez que para nada serviam as palavras e as vozes em tal desordem e confusão. Até que os amigos e os parentes dos tribunos da plebe perceberam que não conseguiriam levar Márcio dali para fora para o punir sem uma grande matança de patrícios, pelo que os convenceram a retirar à pena o que ela tinha de inusitado e de excessivo, não o condenando

${ }^{76}$ Referência ao castigo da rocha Tarpeia. Esta localizava-se no Capitólio e era de lá que os condenados à morte, designadamente os tidos como traidores a Roma, eram lançados. Sobre o mito e funçóes da rocha Tarpeia, ver Rodrigues (2005), 139-144, e bibliografia aí citada, bem como E. Cantarella, Los suplicios capitales en Grecia y Roma, Madrid, 1996, 220-244. 
à morte pela força e sem julgamento, mas concedendo ao povo a possibilidade de actuar de acordo com o seu voto. 6. Mais calmo, Sicínio perguntou então aos patrícios qual era o objectivo ao retirar Márcio ao povo, se este o queria castigar. 7. Por sua vez, estes perguntaram: "Qual é a vossa intenção e o que pretendeis vós ao conduzir assim, sem julgamento, um dos mais ilustres romanos a uma punição cruel e ilegal?» 8. "Pois bem», disse Sicínio, «não façais disto um motivo para dissensóes e sedição contra o povo, pois o que pedis é-vos concedido: que o homem seja julgado. 9. E a ti Márcio, ordenamos-te que te apresentes ao terceiro dia de mercado ${ }^{77}$ e que, se fores inocente, convenças disso os cidadãos. Eles decidirão com o seu voto.»

19. 1. Assim, os patrícios concordaram com este desfecho e retiraram-se satisfeitos, juntamente com Márcio. O tempo que faltava até ao terceiro dia de mercado - entre os Romanos, os mercados realizam-se em cada nove dias e são chamados de nundina ${ }^{78}$ - e a campanha levada a cabo contra os Anciates, que seria longa, davam-lhes esperança de que o povo se acalmasse e apaziguasse a sua ira, ou de que esta desaparecesse mesmo por completo entre os afazeres da guerra. 2. Mas

${ }^{77}$ Referência ao trinundinum ou período de tempo que devia decorrer entre o anúncio oficial de algo que viesse a ser discutido nos comitia e a sua concretizaçáo. I.e., devia passar um tempo que incluísse três dias de mercado. Segundo Dionísio de Halicarnasso, Antiguidades Romanas 7, 58, e o próprio Plutarco no parágrafo 19 desta biografia, em Roma, havia um dia de mercado de nove em nove dias (nundinae).

${ }^{78}$ Em latim helenizado, no original: noundinai. Ver nota anterior. 
tendo-se reconciliado rapidamente com os Anciates, os patrícios regressaram e reuniram-se muitas vezes, pois tinham medo e ponderavam a forma de não entregar Márcio, ao mesmo tempo que evitavam dar aos demagogos pretextos para se relançar a confusão entre o povo. 3. Então, Ápio Cláudio ${ }^{79}$, que tinha a reputação de ser o maior adversário do povo, protestou dizendo que destruiriam o senado e trairiam a república, caso aceitassem que o povo tivesse o poder de votar contra os patrícios. Mas, em contrapartida, os anciáos e protectores do povo consideravam que, se fosse esse o caso, o povo não seria cruel nem duro, mas antes gentil e humano, 4. visto que náo desprezava o senado, mas se acreditava desprezado. Assim, julgar seria para ele uma honra e uma consolação e assim que possuísse o voto poria de lado a ira.

20. 1. Ao ver que o senado se debatia entre a boa vontade para com ele e o medo do povo, Márcio perguntou aos tribunos da plebe de que o acusavam e por que razão seria julgado, quando o levassem perante o povo. 2. Aqueles disseram que a acusaçáo era de tirania e que provariam que era intenção dele ser tirano. Então, ele levantou-se e disse que iria falar em sua defesa perante o povo e que náo escaparia a nenhum tipo de julgamento nem a nenhum castigo, caso fosse condenado. "Mas», disse, "acusai-me apenas disso e não sejais desleais para com o senado». Eles concordaram e

${ }^{79}$ Cônsul em 495 a.C. Aparentemente, era um franco e forte opositor da plebe. 
foi assim que se fez o julgamento. 3. Uma vez reunido o povo, começaram por fazer força para que a votação se fizesse por tribos e não por centúrias, conseguindo assim os votos da multidão indigente, intriguista e desprovida de moralidade, ultrapassando os dos ricos, dos notáveis e dos militares ${ }^{80} .4$. Depois, deixaram cair a acusação de tirania, por ser indemonstrável, e voltaram a recordar discursos proferidos anteriormente por Márcio no senado, quando intercedeu contra os baixos preços do mercado e se manifestou contra o tribunato da plebe. 5. Por conseguinte, apresentaram uma nova acusação contra ele, relacionada com a distribuição do espólio que tinha angariado no território dos Anciates e que distribuíra pelos seus companheiros de armas em vez de entregar ao erário público. Segundo dizem, esta foi a acusação que mais perturbou Márcio, 6. pois não a esperava, pelo que, naquele momento, não conseguiu fazer um discurso convincente perante a multidão.

${ }^{80}$ Aqui faz-se uma referência aos comitia tributa, que se deverão ter constituído apenas no século IV a.C. e que eram convocados pelos tribunos da plebe, por oposição aos comitia centuriata. Enquanto estes se organizavam com base nos censos, aqueles formavam-se com base em circunscriçóes territoriais, votando todas as tribos de Roma. Dionísio de Halicarnasso, Antiguidades Romanas 7, 59, explica que esta foi a primeira vez que a assembleia se reuniu em comícios tributos e não em centuriatos, mas deverá tratar-se de um anacronismo. De qualquer forma, os comícios centuriatos foram durante muito tempo a mais importante das assembleias do povo e tinham atribuiçóes eleitorais, legislativas e judiciárias, intervindo ainda nas declaraçóes de guerra e na celebração de tratados. Ver J. Gaudemet, Les institutions de l'Antiquité, Paris, 20027, 158-165. Sobre a composição das 193 centúrias, divididas de acordo com a propriedade e o posto nas batalhas, assim como a ordem na votação, ver Dionísio de Halicarnasso, Antiguidades Romanas 7, 59. 
Elogiou publicamente os soldados envolvidos, mas provocou o descontentamento daqueles que não tinham participado e que eram em número superior. 7. No fim, quando as tribos votaram, foram três as que acabaram por deliberar a condenação***81. A punição dada em sentença foi o banimento perpétuo. 8. Depois da proclamação, o povo retirou-se dali presunçoso e contente como jamais se sentira, nem sequer depois de ter vencido um inimigo em combate. Mas o senado foi dominado pela dor e por uma terrível tristeza, arrependido e afligido por não ter tomado todas as medidas e todos os sofrimentos, em vez de permitir ao povo tais excessos e o uso de tanto poder. 9. Naquele momento, náo eram necessárias as vestes ou outros sinais externos para fazer distinçóes, sendo imediatamente reconhecíveis o plebeu feliz e o patrício contristado.

21. 1. Márcio era a única excepção. Intrépido e nada assustado, mantinha a sua atitude, andar e semblante calmos. Enquanto todos os outros sofriam, só ele parecia não ser afectado. E não era por ponderação ou por brandura ou sequer por moderação que ele suportava o que lhe acontecera, mas porque estava afectado pela ira e pela indignação, que a maioria desconhece como formas

${ }^{81}$ Sabemos que o número de tribos votantes era de 21, pelo que o resultado da votação deverá ter sido de 9 a favor de Márcio e 12 contra Márcio. A diferença entre os dois valores é igual a 3, ou seja, as tais tribos que Plutarco afirma terem sido as que acabaram por decidir a condenação. Sobre esta questão, ver PÉrez Jiménez (2006), 96, n. 89. 
de sofrimento. 2. Efectivamente, sempre que se transforma em ira, é como se se incendiasse, deixando para trás o abatimento e a indolência. Daí que o encolerizado pareça sempre muito activo, tal como quem está febril quando fica muito quente, visto que a sua alma pulsa de tensão e inflamação. 3. Logo a seguir, Márcio demonstrou ainda mais este estado de espírito através das suas acções. Ao entrar em casa, abraçou a mãe e a mulher, que se lamentava entre choros e gemidos, e ordenou-lhes que aceitassem com resignação o que sucedera. E, erguendo-se, saiu em direcção às portas ${ }^{82} .4$. Os patrícios escoltaram-no todos juntos até ali e ele, sem nada tomar ou pedir-lhes, partiu, levando consigo três ou quatro clientes ${ }^{83}$. 5. Durante uns poucos dias, permaneceu numa das suas terras, debatendo consigo mesmo as várias perspectivas com que a ira o provocava. Ao concluir que o bom e adequado seria punir os Romanos, resolveu provocar uma guerra terrível entre eles e os seus vizinhos. 6. Assim, decidiu tentar, em primeiro lugar, com os Volscos, pois sabia que eram suficientemente fortes em homens e em dinheiro, e porque teve em conta que as derrotas recentes, mais do que diminuir a sua força, haviam aumentado a rivalidade e a raiva.

22. 1. Havia um homem da cidade de Âncio, chamado Tulo Átio ${ }^{84}$, que, pela riqueza, coragem elinhagem,

${ }^{82}$ Subentende-se «as portas da cidade».

${ }^{83} \mathrm{Na}$ sociedade romana arcaica, um cliente era geralmente um homem pobre que se colocava sob a protecção de um vizinho mais rico e mais poderoso

${ }^{84}$ Não existe consenso em torno do outro nome de Tulo. 
tinha a reputação de um rei entre todos os Volscos. 2. Márcio sabia que ele o odiava mais do que a qualquer outro Romano. Pois, muitas vezes, em batalha, trocaram ameaças e, jactando-se, desafiaram-se mutuamente, qual produto da ambição da glória própria dos jovens guerreiros. Por conseguinte, ao ódio público ${ }^{85}$ acrescentaram entre eles o privado. 3. Mas ao ver que esse tal Tulo tinha grandeza de espírito e que, dos Volscos, era o que mais desejava atacar os Romanos e por sua vez causar-lhes a humilhação, ele assumiu o testemunho de quem disse que «é difícil combater irado, pois compra-se com a vida tudo o que se deseja.» ${ }^{86} 4$. Assim, pegou nas roupas e no equipamento com o qual seria menos esperado, caso o vissem, e qual Ulisses «penetrou numa cidade de inimigos» ${ }^{87}$.

23. 1. A tarde já tinha caído e ele cruzou-se com muita gente, mas ninguém o reconheceu. Dirigiu-se entáo à casa de Tulo e entrou de rompante. Sentou-se à lareira, em silêncio. Com a cabeça coberta, manteve-se quieto. 2. Os da casa ficaram intrigados, mas não se

Algumas ediçôes do texto apresentam "Anfídio» ou "Aufídio». Mas os editores, designadamente Ziegler, têm corrigido esta forma para "Átio" (Attios), de modo a fazê-la coincidir com o que Cícero, Tito Lívio e Dionísio de Halicarnasso escrevem. Ver Russell (1963) 22.

${ }^{85}$ I.e., entre os dois povos.

${ }^{86}$ Heraclito, frg. 85 Diels-Kranz. Plutarco cita esta mesma frase de Heraclito de Éfeso no tratado Da contenção da ira 9, 457D e no Erótico 755D. Aristóteles recorreu também a esta sentença por várias vezes: Ética a Eudemo 2, 7, 1223b2; Ética a Nicómaco 2, 2, $1105 \mathrm{a} 8$ e Politica 5, 11, 1315a19.

${ }^{87}$ Odisseia 4, 246. Verso homérico proferido por Helena, que se refere à forma como Ulisses se disfarçou e entrou em Tróia. 
atreveram a fazê-lo levantar-se - havia dignidade nele, na sua figura e no seu silêncio. Foram então contar a Tulo, que estava a cear, o insólito da circunstância. 3. Este levantou-se, foi ter com aquele e perguntou-lhe quem era para ali vir e o que queria. Nesse momento, Márcio descobriu-se e depois de se conter por um pouco, disse: "Se ainda não me reconheceste, Tulo, ou se náo acreditas no que estás a ver, então tenho de me denunciar. 4. Sou Gaio Márcio, aquele que pior vos tratou, a ti e aos Volscos. O cognome que carrego, Coriolano, não o deixa negar. 5. Não ganhei nenhum outro prémio daqueles muitos trabalhos e perigos senão o nome, marca da minha inimizade para convosco. 6. Só isso me resta e não mo podem tirar. De tudo o resto fui privado, pela inveja e pela insolência do povo, pela fraqueza e pela traição dos magistrados e dos meus pares. Fui obrigado a fugir, pelo que vim ao teu lar como suplicante. Não em busca de segurança e salvação - pois porque viria aqui se tivesse medo de morrer? -, mas porque, em vez disso, desejo vingança, que já vou tendo ao entregar-me e ao fazer de ti meu senhor. 7. Por isso, se desejas atacar os teus inimigos, avança, ó de nobre raça, que eu cedo-te as minhas desgraças. Faz da minha desventura o êxito de todos os Volscos. Serei melhor a fazer a guerra por vós do que contra vós, tal como lutam melhor todos os que conhecem o lado do inimigo do que os que o desconhecem. 8. Mas se já desististe, então não quero viver mais, e nem para ti é bom salvar um homem que foi teu inimigo em combate e que agora não te é útil nem proveitoso.»9. Quando Tulo ouviu isto, sentiu 
uma prazer enorme. Estendeu-lhe a mão direita e disse: «Levanta-te, Márcio, e ganha coragem! Pois grande é o bem que nos trazes, ao entregares-te a ti próprio. Espera pois muito mais dos Volscos.»10. Então, gentilmente, convidou Márcio para a sua refeição e planearam juntos a guerra, nos dias que se seguiram.

24. 1. Enquanto isso, em Roma, a hostilidade dos patrícios para com o povo, a quem sobretudo culpavam pela condenação de Márcio, estava a provocar distúrbios. Adivinhos, sacerdotes e outros indivíduos anunciavam muitos prodígios que mereciam atenção ${ }^{88}$. Eis um dos que, segundo se diz, aconteceu. 2. Havia um tal Tito Latínio, homem pouco de dar nas vistas mas ponderado e comedido e, sobretudo, nada supersticioso e sem falsas pretensóes. 3. Esse homem acreditava ter visto Júpiter ${ }^{89}$, que lhe teria aparecido num sonho e mandado dizer no senado que o dançarino que haviam escolhido para pôr à frente da procissão em sua honra era mau e aziago ${ }^{90}$. 4. Ao princípio, dizia ele, quando teve a visão, não lhe deu muita consideração. Mas depois que a teve uma segunda e uma terceira vez, e que continuou sem lhe dar qualquer importância, assistiu à morte do seu bom filho e, ele próprio, ficou repentinamente paralisado do corpo e impotente. 5. Então, fez-se carregar numa

88 Sobre estes prodígios, ver Dionísio de Halicarnasso, Antiguidades Romanas 7, 68-73.

${ }^{89}$ Seria Júpiter, mas Plutarco utiliza, naturalmente, a designação grega «equivalente»: Zeus.

${ }^{90}$ Referência aos ludi magni. $\mathrm{O}$ dançarino que seguia à frente da procissão recebia o nome de praesultator. 
liteira e contou estas coisas no senado. E diz-se que, assim que acabou de contar isto, o seu corpo recuperou as forças, levantou-se e saiu dali pelo seu próprio pé. Os senadores, perplexos, fizeram muitas perguntas sobre o assunto. 6. E o que aconteceu foi o seguinte: um deles entregara um servo da sua casa a outros servos igualmente seus, com ordem de o levarem para o foro, o chicotearem e de seguida o matarem. Quando os homens o estavam a torturar e ele se contorcia com todo o tipo de dores e fazia outros movimentos repugnantes por causa da tortura, a Fortuna ${ }^{91}$ fez com que a procissão passasse por ele. 7. Muitos dos presentes ficaram desagradados, pois nem o espectáculo era bonito de se ver, nem os movimentos próprios. Ninguém agiu contra aquilo, todavia, apenas censurando e insultando quem punia com tanta crueldade. 8. Naquele tempo, tratavam-se os servos domésticos com muita bondade, já que se partilhava do seu modo de vida, fazendo-se inclusivamente trabalho manual. Eram por isso gentis no convívio com eles. 9. No caso de um servo doméstico cometer uma falta, seria um grande castigo fazê-lo andar pela vizinhança carregando às costas a peça de madeira que apoia o timão de um carro. Pois aquele que sofresse tal castigo e que assim fosse visto pelos companheiros da sua casa e vizinhos perderia toda a sua credibilidade. 10 . Chamavam-lhe furcifer $^{22}$, pois aquilo a que os Helenos

${ }^{91}$ Plutarco usa tyche.

${ }^{92} \mathrm{O}$ vocábulo latino furcifer, que significa «o que leva ou merece a forca», é usado por Plutarco numa «versão» helenizada, phourkipher. 
chamam «suporte» ${ }^{93}$ e «apoio» ${ }^{94}$, os Romanos chamam furca ${ }^{95}$.

25. 1. Assim que Latínio lhes relatou o que vira, e eles se perguntavam sobre quem seria o aziago e mau dançarino que ia à frente da procissão, alguns lembraram-se, pela singularidade do caso, da punição daquele criado, a quem arrastaram pelo foro a chicote e depois mataram. $\mathrm{O}$ amo foi punido com a concordância dos sacerdotes e voltou-se a celebrar a procissão e o espectáculo desde o início ${ }^{96} .2$. Ao que parece, $\mathrm{Numa}^{97}$ foi um intérprete competente de todo o sagrado e ter-lhes-á dado esta norma, excelente para manter o escrúpulo ${ }^{98}$ religioso. 3. Sempre que os magistrados ou os sacerdotes reverenciam algum dos deuses, o arauto precede-os,

${ }^{93}$ Em grego hypostates.

${ }^{94} \mathrm{Em}$ grego sterigma.

95 Numa espécie de transliteração, Plutarco usa o termo «helenizado» phourka. Trata-se do pau bifurcado ou madeiro com duas pontas para castigo dos servos, com a qual o condenado efectuava um passeio ignominioso sob fustigaçóes. Era assim levado a golpes até ao lugar do suplício final, onde era morto de acordo com a pena prevista pela lei para o crime cometido. Ver E. Cantarella, Los suplicios capitales en Grecia y Roma, Madrid, 1996, 187-190. Esta mesma historieta é contada por Cícero, Da adivinhação 1, 55; Dionísio de Halicarnasso, Antiguidades Romanas 7, 68-73; Tito Lívio 2, 36; Valério Máximo 1, 7, 4; Macróbio, Saturnais 1, 11, 3; Lactâncio, Instituiçóes divinas 2, 8.

${ }_{96} \mathrm{O}$ relato que Plutarco aqui apresenta refere-se à norma da instauratio, própria da religião romana e que consistia na «renovação", «restauração» ou "reconstrução» de toda e qualquer cerimónia religiosa celebrada de forma defeituosa ou interrompida por um incidente de mau augúrio.

${ }^{97}$ Numa Pompílio.

${ }^{98}$ Em grego, eulabeia. 
gritando a voz alta: hoc age ${ }^{99}$. 4. A frase significa «Ocupa-te disto!» e incentiva-os a continuar os rituais sagrados e a náo misturar com eles nenhum trabalho nem qualquer outra ocupação, pois a maioria das coisas humanas faz-se porque é necessário que se faça e por coacção. 5. Entre os Romanos, é costume recomeçar-se os sacrifícios, as procissôes e os espectáculos não apenas por um motivo táo importante como este, como também por pequenas coisas. 6. Assim, basta que um dos cavalos que puxa as chamadas tensae ${ }^{100}$ afrouxar ou que o auriga tome as rédeas com a mão esquerda, para se decretar que a procissão recomece. 7. Em tempos posteriores, chegaram a fazer um só sacrifício trinta vezes, sempre que surgia algo mal feito ou alguma mácula. Era assim o escrúpulo ${ }^{101}$ dos Romanos em relação aos deuses.

26. 1. Márcio e Tulo mantiveram conversações secretas com os mais poderosos em Âncio. Exortavam-nos a declarar guerra aos Romanos, enquanto estes se entretinham em discórdias internas. 2. Mas eles sentiam-se envergonhados, porque tinham feito tréguas e havia um armistício por dois anos. Foram os próprios Romanos, porém, a oferecer um pretexto, quando alguém, por suspeita ou calúnia, anunciou num espectáculo durante os jogos que os Volscos iriam sair da cidade antes do pôr-do-sol. 3. Alguns dizem que isto foi um truque e um

${ }^{99}$ Expressão latina transliterada em grego, no original.

${ }^{100}$ Em grego, thessas. Trata-se dos carros sagrados em que se transportavam as imagens dos deuses nos ludi circenses; cf. Cícero, Da resposta dos harúspices 23.

${ }^{101}$ Em grego, eulabeia. 
dolo de Márcio, que enviou aos magistrados de Roma um falso acusador dos Volscos, como se planeassem atacar os Romanos durante os espectáculos e lançar fogo à cidade ${ }^{102}$. 4. Ora, esta proclamação aumentou a hostilidade de todos os Volscos para com os Romanos. Tulo empolou a questão até ao exagero com o objectivo de os provocar e acabou por convencê-los a enviar a Roma alguém para reclamar a devolução das terras e cidades que haviam sido retiradas aos Volscos na guerra. 5. Quando ouviram os embaixadores, os Romanos ficaram irritados e responderam que os primeiros a pegar nas armas seriam os Volscos, mas que os Romanos seriam os últimos a pousá-las. 6. Perante isto, Tulo reuniu uma assembleia com toda a gente e, depois de terem votado pela guerra, aconselhou-os a chamar Márcio, sem recordar quaisquer injúrias passadas, mas confiando que enquanto aliado ele seria de uma ajuda tão grande para o povo quanto prejudicial tinha sido enquanto inimigo.

27. 1. Assim que foi chamado, Márcio discursou para a multidáo, revelando-se náo menos capaz com as palavras $^{103}$ [do que na guerra], quer pela sua inteligência quer pela notável coragem. Por isso, foi designado juntamente com Tulo comandante plenipotenciário para a guerra. 2. Temendo que faltasse tempo aos Volscos para se equiparem, e que se retardasse em muito o tempo de agir, ele ordenou aos poderosos e

102 Entre esses «alguns» estão Dionísio de Halicarnasso, Antiguidades Romanas 8, 2-4, e Tito Lívio 2, 3738.

103 Dionísio de Halicarnasso, Antiguidades Romanas 8, 5-8, apresenta um longo discurso atribuído a Gaio Márcio. 
aos magistrados de cada cidade que reunissem tropas e provisóes, enquanto ele convencia os mais zelosos a que o seguissem prontamente sem se registarem. Foi assim que ele invadiu súbita e inesperadamente o território dos Romanos $^{104}$. 3. Desse modo, conseguiu um despojo tão grande que os Volscos tiveram de recusar-se a carregá-lo e a levá-lo para o acampamento. 4. Mas, para ele, a abundância e os muitos estragos e males que espalhassem pelo território com aquela campanha eram uma questáo menor. $\mathrm{O}$ grande objectivo era: desacreditar ainda mais os patrícios perante o povo. 5. Enquanto destruía e arruinava tudo o resto, defendia energicamente as terras dos patrícios e não permitia que lhes causassem dano e que delas colhessem fosse o que fosse. 6. Por essa razão, as querelas e os distúrbios aumentaram em ambos os lados. Os patrícios acusavam os restantes de terem expulsado injustamente um grande homem; e o povo acusava-os de terem lançado Márcio contra eles por vingança, para depois ficarem sentados a assistir aos outros em guerra, enquanto tinham do lado de fora o próprio inimigo a servir de guardião das suas riquezas e valores. 7. Depois de ter conseguido isto e ajudado em muito os Volscos a ganharem coragem e a desprezarem os inimigos, Márcio regressou com eles a casa, em segurança.

28. 1. Assim que todas as forças dos Volscos rápida e prontamente se reuniram, revelaram-se tão

104 Dionísio de Halicarnasso, Antiguidades Romanas 8, 11, é mais pormenorizado nesta descriçáo, referindo que foram várias as campanhas dos Volscos contra os Romanos e os Latinos. Outra descrição pode ser lida em Tito Lívio 2, 39. 
numerosas que eles decidiram deixar para trás uma parte do exército, para segurança das cidades, e avançar com a outra parte contra os Romanos. Márcio deixou que Tulo escolhesse o comando de uma das duas forças. 2. Tulo respondeu-lhe que para ele era evidente que Márcio não lhe era inferior em coragem, mas mais afortunado em todas as batalhas, pelo que o exortou a comandar os que partiam, ficando ele para trás, a guardar as cidades e a providenciar tudo aquilo de que os soldados da expedição necessitassem. 3. Mais entusiasmado ainda, Márcio avançou primeiro contra Circeu, cidade que era uma colónia dos Romanos ${ }^{105}$. Como esta se rendeu voluntariamente, ele não lhe fez mal algum. 4. Depois, devastou o país dos Latinos, esperando que aí os Romanos viessem combatê-lo, pois os Latinos eram seus aliados e não raramente apelavam à sua ajuda. 5. Mas uma vez que a plebe estava desmotivada e aos cônsules faltava pouco tempo no cargo ${ }^{106}$ e por isso náo queriam arriscar, mandaram embora os enviados pelos Latinos ${ }^{107}$. Por conseguinte, Márcio avançou contra as próprias cidades dos Tolerinos $^{108}$, dos Labicos ${ }^{109}$, dos Pedanos ${ }^{110}$ e dos

${ }^{105}$ Circeu localizava-se ao sul da região habitada pelos Volscos, na costa do Lácio. Era célebre no Mundo Antigo pelas suas ostras. 106 Trata-se dos cônsules do ano 489 a.C., Gaio Júlio Iulo e Públio Pinário Mamertino Rufo.

107 Subentende-se "os embaixadores enviados pelos Latinos». Literalmente, lemos apenas "os dos Latinos».

${ }^{108}$ Habitantes de Tolério, cidade latina.

${ }^{109}$ Habitantes de Labico que era uma cidade do Lácio localizada entre Túsculo e Preneste.

${ }^{110}$ Habitantes de Pedo que era uma cidade do Lácio localizada perto de Preneste. 
Bolanos ${ }^{111}$, que resistiram e que por isso ele tomou à força, fazendo das pessoas prisioneiros de guerra e saqueando os seus tesouros. 6. Aos que se puseram ao lado dele, ele mostrou grande consideração: para que não sofressem males contra a sua vontade, acampava longe deles e mantinha-se fora do seu território ${ }^{112}$.

29. 1. Depois de conquistar Boila ${ }^{113}$, cidade que estava a não mais de cem estádios de Roma ${ }^{114}$, apoderou-se de muitas riquezas e matou quase todos os que estavam em idade militar. Então, nem mesmo os Volscos que tinham sido designados para ficarem nas cidades se mantiveram aí e, levando consigo as armas, foram ter com Márcio, dizendo que só ele era o general e o único a quem reconheciam como seu comandante. Desde logo, por toda a Itália, o seu nome foi engrandecido e admirável a sua glória, pois a coragem de um só indivíduo, ao mudar de campo, acabou por, além de qualquer expectativa, mudar as circunstâncias. 2. Entretanto, do lado dos Romanos reinava uma grande falta de ordem. Haviam desistido de combater e permaneciam dias inteiros em conflitos e a discutir uns com os outros, até que receberam a notícia

${ }^{111}$ Habitantes de Bola ou Vola, cidade latina.

112 Segundo Dionísio de Halicarnasso, Antiguidades Romanas 8, 19, as cidades que se mantiveram ao lado de Gaio Márcio Coriolano foram Corbião e Coríolos.

113 Esta cidade não é a mesma citada em 28, 5. Aí lemos Bôlanous de Bôla; aqui lemos Boïllas. Ver Pérez Jiménez (2006), 107, n. 127. Sobre estas cidades e populaçóes, ver CoRnell (1995) 293-326.

${ }^{114}$ C. $18 \mathrm{~km}$. 
do cerco de Lavínio ${ }^{115}$ pelos inimigos. Era ali que os Romanos conservavam as coisas consagradas aos deuses pátrios e ali estava a origem da sua gente, pois aquela foi a primeira cidade fundada por Eneias. 3. Disto resultou uma extraordinária mudança de opiniáo em todo o povo e uma outra, inusitada e totalmente inesperada, entre os patrícios. 4. Com efeito, o povo propôs a anulaçáo do castigo de Márcio e chamá-lo para a cidade ${ }^{116}$. Mas o senado, reunido para examinar a proposta, opôs-se e rejeitou-a, quer porque, por rivalidade, resistia sempre a tudo quanto o povo propunha; quer porque, por outro lado, não queria que o regresso do homem ficasse a dever-se a um favor do povo; ou quer ainda porque já se havia enraivecido contra ele, dado o mal que fazia a todos sem assim ter sido tratado e por se ter proclamado inimigo de toda a pátria, sabendo que nela o partido com mais autoridade e maior poder lhe era simpático por tantas injustiças que lhe haviam sido feitas. 5. Apresentada publicamente a decisão perante a multidáo, o povo ficou sem autoridade, pois o seu voto não fazia lei sem um decreto do senado ${ }^{117}$.

30. 1. Ao saber disto, Márcio irritou-se ainda mais. Levantou o cerco e, encolerizado, avançou contra a cidade ${ }^{118}$. Acampou perto das chamadas Fossas Cluílias,

115 Cidade que se dizia fundada por Eneias no Lácio. Sobre Eneias, ver Rodrigues (2005), 57-101, e bibliografia aí citada.

${ }^{116}$ Roma, naturalmente.

117 I.e., sem um senatusconsultum, que ratificava as decisóes e tinha a força executiva, de facto. Em grego, lemos probouleuma. Ver J. Gaudemet, Les institutions de l'Antiquité, Paris, 20027, 338-339.

${ }^{118}$ Plutarco refere-se de novo a Roma. 
a quarenta estádios da cidade ${ }^{119}$. 2. O seu aparecimento ali foi terrível e lançou tudo num grande tumulto. No entanto, por momentos, pôs fim às dissensóes. Ninguém ousou voltar a falar contra a multidão, nem magistrado nem senador, relativamente ao regresso de Márcio. Ao verem as mulheres correrem pela cidade de um lado para o outro e os velhos irem como suplicantes aos templos chorar e rogar, e que por todo o lado faltava a coragem e planos para se salvarem, reconheceram que o povo tinha razão, quando procurava reconciliar-se com Márcio e que o senado estava totalmente errado, desencadeando a ira e o rancor quando o certo seria acabar com eles. 3. Então, todos pensaram em enviar uma embaixada a Márcio, oferecendo-lhe o regresso à pátria e pedindolhe que acabasse a guerra com eles. 4. Os delegados do senado eram parentes de Márcio, pelo que esperavam ser favoravelmente recebidos logo na primeira audiência pelo homem que era seu familiar e amigo. 5. Mas nada disso aconteceu. Depois de conduzidos pelo acampamento dos inimigos, foram encontrá-lo sentado, orgulhoso e com uma arrogância insuportável. 6. Com os primeiros dos Volscos junto de si, ele convidou-os a dizerem o que tinham ido pedir. 7. Eles falaram com palavras moderadas e afáveis, como era apropriado. E quando terminaram, ele respondeu por si, com amargura e ira pela forma como tinha sido tratado, e depois enquanto general dos Volscos, exigindo a restituição das cidades e do mesmo território

119 As fossas Cluílias eram canais situados ao longo da via Ápia, que deviam o seu nome ao ditador Albano Cluílio e que determinavam a fronteira entre Roma e Alba Longa. Ficavam a c. 7 km de Roma. 
que lhes havia sido tomado pela guerra. $\mathrm{E}$ ainda que se decretasse para os Volscos a igualdade de direitos cívicos que havia sido outorgada aos Latinos. 8. Pois não havia outra garantia para acabar com a guerra que não fosse a da igualdade e a da justiça. Deu-lhes o prazo de trinta dias para deliberarem e quando os embaixadores se foram, ele retirou-se imediatamente do país.

31. 1. Esta foi a causa da primeira censura dos Volscos, que há muito estavam fartos e invejosos do seu poder. Um deles era Tulo, não que ele próprio tivesse sido injuriado por Márcio, mas porque ficara enredado em emoçôes tipicamente humanas. 2. Na verdade, sentira-se humilhado com a obscuridade total da sua reputação e com a negligência a que fora votado pelos Volscos, para quem Márcio era tudo e que pensavam que os outros deviam ficar satisfeitos com o quinhão de poder e de autoridade que ele lhes tolerava. 3. Por isso, as primeiras acusaçôes corriam em segredo. Eles reuniam-se para partilhar uns com os outros a irritação e chamar traição àquela retirada, não porque tivessem deixado escapar muralhas ou armas, mas sim uma daquelas ocasióes em que tudo se salva ou perde. Pois dera trinta dias de tráguas à guerra, quando muito pode mudar em tão pouco tempo. 4. Márcio, porém, durante esse tempo, não esteve sem fazer nada. Atacava os aliados dos inimigos, destruía e saqueava. Tomou sete grandes e populosas cidades ${ }^{120} .5$. Os Romanos não ousavam ir em seu auxílio, pois as suas almas mantinham-se temerosas e

${ }^{120}$ Sobre os nomes dessas cidades, ver Dionísio de Halicarnasso, Antiguidades Romanas 8, 36. 
também pouco dispostas para a guerra, como se o corpo tivesse inchado e paralisado por completo. 6. Algum tempo depois, Márcio voltou a aparecer com todo o seu exército. De novo lhe enviaram uma embaixada para lhe pedir que deixasse a sua ira desaparecer e que, depois de fazer com que os Volscos saíssem do território, dissesse e fizesse o que considerasse ser o melhor para ambos os povos, pois os Romanos nada cederiam ao medo. E se por acaso pensava que os Volscos deviam ser tratados com humanidade, tal poderia acontecer desde que depusessem as armas. 7. A isto, Márcio disse que, enquanto general dos Volscos, nada respondia; mas que enquanto cidadão de Roma, que ainda era, aconselhava-os e convidava-os a moderar as suas pretensóes de justiça, e a apresentarse perante si dentro de três dias, depois de terem votado aquilo que lhes era proposto. E caso decidissem de outro modo, ficassem a saber que não garantiria a sua segurança quando regressassem ao seu acampamento com palavras ocas.

32. 1. Assim que os embaixadores regressaram, o senado ouviu-os, ergueu e lançou a âncora sagrada, como se a cidade estivesse no meio de uma grande tempestade e de vagas marítimas ${ }^{121}$. 2. Decidiu-se então enviar a Márcio todos os que fossem sacerdotes dos deuses ou celebrantes e guardiães de mistérios ou que praticassem a adivinhação a partir de aves, que era uma antiga tradição dos antepassados, adornados segundo o costume de cada um nos respectivos ofícios religiosos,

${ }^{121}$ Como notam Pérez Jiménez (2006), 112, n. 138, o recurso à metáfora marítima, em que a cidade é comparada a um navio, é recorrente na literatura clássica e eficaz na formulação do patético. 
para lhe dizerem o mesmo e assim convencê-lo a desistir da guerra, para depois conversar sobre os Volscos com os cidadãos. 3. Pois ele aceitou que os homens fossem ao acampamento, mas náo lhes ofereceu nada mais, nem o que disse ou o que fez foi mais gentil. Em vez disso, incitouos a aceitarem a solução, tal como antes postulada, ou a guerra. 4. Quando os sacerdotes voltaram, decidiram permanecer em calma na cidade, manter a guarda nas muralhas e expulsar os inimigos em caso de ataque. Depositavam as suas esperanças no tempo, sobretudo, e nos acasos imprevistos da Fortuna $^{122}$, pois sabiam que por si mesmos nada podiam fazer para se salvarem. O tumulto, o temor e os rumores maliciosos dominavam a cidade. Por fim, aconteceu algo semelhante ao que Homero tantas vezes diz, e em que muitos não acreditam. 5. Quando, a propósito dos grandes feitos e dos imprevistos, ele afirma e proclama:

Então, Atena, a deusa de olhos garços, inspirou-o $0^{123}$,

e ainda:

mas um dos imortais me acalmou a ira, pondo-me no peito a voz do povo ${ }^{124}$,

e ainda mais:

122 Tyche.

${ }^{123}$ Odisseia 18, 158, e 21, 1. Referência ao facto de Penélope agir por inspiraçáo de Atena.

124 Ilíada 9, 459-460. Passo do discurso de Fénix a Aquiles. Relativamente às citaçóes da Ilíada e da Odisseia, com excepçáo dos versos assinalados com as notas 123 e 127, usamos as traduçóes de F. Lourenço. 
ou porque suspeitava alguma coisa, ou porque um deus tho dissera. $^{125}$

Palavras estas que são vistas com desdém, com o argumento de que ficçóes impossíveis e histórias incríveis retiram à inteligência de cada um a faculdade de escolher ${ }^{126}$. 6. Mas Homero não faz isso, uma vez que nos atribui tudo o que é verosímil, comum e razoável. De facto, ele diz muitas vezes:

Decidi então no meu espírito magnânimo ${ }^{127}$,

e:

Assim falou. Mas uma dor se apoderou do Pelida, cujo coração no peito hirsuto se dividia no que haveria de pensar ${ }^{128}$,

e de novo:

mas de forma alguma logrou convencer quem albergava bons pensamentos: o fogoso Belerofonte. ${ }^{129}$

7. Quanto às acçóes inusitadas e extraordinárias, que implicam algum entusiasmo e exaltação, a divindade é representada não a anular mas a excitar

${ }^{125}$ Odisseia 9, 339. Passo relativo ao episódio do ciclope.

${ }^{126}$ Possível crítica de Plutarco a Platão, A República 377b-378e.

127 Odisseia 9, 299. Fala de Ulisses no episódio do ciclope.

128 Ilíada 1, 188. Passo referente à contenda entre Aquiles e Agamémnon no início da Ilíada.

${ }^{129}$ Ilíada 6, 161. Passo do episódio de Belerofonte. 
a liberdade mental; não a produzir impulsos mas as ideias que geram os impulsos, as quais fazem com que a acção não seja involuntária, legitimando, em vez disso, a vontade e imputando-lhe ainda a confiança e a esperança. 8. Se retiramos aos deuses todo o controlo sobre as causas e os princípios das nossas acçóes, de que outro modo podem eles ajudar os homens a cooperar consigo? Não é certamente modelando o nosso corpo, nem, presumo, movendo as nossas mãos e os nossos pés, mas despertando o princípio prático e selectivo da nossa alma, com princípios, imagens e pensamentos ou, pelo contrário, fazendo-a recuar e parar ${ }^{130}$.

33. 1. Entretanto, em Roma, algumas mulheres dirigiram-se a uns templos e outras a outros. Mas a maioria e as mais notáveis foram como suplicantes ao altar de Júpiter Capitolino. Entre estas estava Valéria, a irmã de Publícola, o que realizou tantas e tão grandes acçôes pelos Romanos, quer na guerra quer na governação. 2. Por esta altura, já Publícola tinha morrido, como escrevemos na obra sobre ele ${ }^{131}$, e Valéria era respeitada e honrada na cidade, pois a sua vida em nada desonrava a sua linhagem. 3. Subitamente, ela sentiu o impulso de que falei ${ }^{132}$ e agiu de acordo com um pensamento, ao qual não foi estranha

130 Este parágrafo consiste num exercício hermenêutico de Plutarco acerca do livre-arbítrio humano, feito com recurso aos Poemas Homéricos, tidos como educadores da Grécia. Note-se como as concepçóes plutarquianas se revelam próximas das cristâs, designadamente no que diz respeito ao problema da liberdade e da responsabilidade humanas. Ver PÉREz Jiménez (2006), 115, n. 147.

${ }^{131}$ Plutarco, Publícola 23.

${ }^{132}$ I.e., no parágrafo 32. 
a inspiração divina: levantou-se e fez levantar todas as outras e foi à casa de Volúmnia, a mãe de Márcio. 4. Ao entrar, encontrou-a sentada com a nora e com os filhos de Márcio sobre os joelhos. Então, fez com que as mulheres se pusessem à volta dela e disse: 5. «Somos nós mulheres, por nossa iniciativa, Volúmnia e tu Vergília ${ }^{133}$, que nos dirigimos a mulheres, não por uma votação do senado nem a pedido de um magistrado. Foi antes o deus que, segundo creio, compadecido pelas nossas súplicas, nos inspirou a ideia de virmos aqui rogar-vos por algo que vos salvará a vós próprias e aos outros cidadãos e que, se nos ouvirdes, vos trará uma reputação ainda mais brilhante do que a que tiveram as filhas dos Sabinos, quando juntaram os pais e os maridos na amizade e na paz, acabando com a guerra ${ }^{134}$. 6. Vamos! Vinde connosco perante Márcio, juntai-vos à nossa súplica e dai da pátria o testemunho verdadeiro e justo de que, apesar dos muitos males que ele a fez sofrer, ela não concretizou nem deliberou nada de terrível contra vós por raiva, mas que, pelo contrário, vos devolve a ele sem ter qualquer intenção de ganhar alguma coisa de útil com isso.» 7. Depois de dizer isto, Valéria foi aclamada pelas restantes mulheres e Volúmnia respondeu-lhe: "Também nós, mulheres, partilhamos da mesma sorte nas desgraças públicas e, em privado, sentimos ainda a de perder a reputação e a virtude de Márcio e de ver o seu corpo mais prisioneiro do que

${ }^{133}$ Vergília é o nome que Plutarco dá à mulher de Coriolano. Noutros autores, ela chama-se Volúmnia que, como vimos, é aqui o nome da mãe. Ver nota ao parágrafo 4.

134 Sobre as Sabinas, ver Rodrigues (2005), 133-138, e bibliografia aí citada. Cf. Plutarco, Rómulo 19. 
salvo pelas armas dos inimigos. 8. Mas a maior das nossas desgraças é que a pátria esteja enfraquecida e que tenha a sua esperança em nós. 9. Mas náo vejo que ele nos leve mais em conta, se não leva a pátria, a quem preferiu à mãe, à mulher e aos filhos. 10. Ainda assim, usa-nos, pega em nós e leva-nos a ele. Se nada mais conseguirmos, pelo menos expiraremos o nosso último suspiro em defesa da pátria.»135

34. 1. Depois disto, ela fez Vergília e as crianças erguerem-se e foi com as outras mulheres até ao acampamento dos Volscos. 2. A sua visão era digna de tanta piedade que impôs a reverência e o silêncio entre os inimigos. Márcio estava num julgamento, sentado sobre a tribuna, com os comandantes. 3. Admirou-se ao ver as mulheres aproximarem-se. $\mathrm{E}$ ao reconhecer a mãe, que vinha à frente, ainda quis manter a sua decisão, inflexível e implacável, mas acabou por se submeter à emoção. Perturbado perante o que via, não conseguiu permanecer sentado enquanto ela se aproximava, pelo que desceu precipitadamente e correu ao seu encontro. Primeiro, e na maior parte do tempo, abraçou a mãe, e depois a mulher e os filhos, sem reter as lágrimas nem as demonstraçóes de carinho, deixando-se levar pela emoção como se fosse uma torrente.

35. 1. Já satisfeito e ao perceber que a mãe queria ser a primeira a falar, dispôs ao seu lado os conselheiros

${ }^{135}$ Sobre a descrição da cena das mulheres em outros autores e respectivas diferenças, ver PÉREZ JiménEZ (2006), 116, n. 154. 
dos Volscos e escutou Volúmnia, que falou assim: 2. «Já vês, meu filho, ainda que não o digamos, mas podes avaliá-lo pelas nossas roupas e pelos aspecto miserável dos nossos corpos, em que tipo de solidão o teu exílio nos lançou. Mas pensa agora como somos as mais infelizes de todas as mulheres que aqui vieram, pois a Fortuna $^{136}$ fez com que o espectáculo mais agradável se tornasse o mais temível: ver um filho, como é para mim, e um marido, como é para esta, acampado em frente às muralhas da sua pátria. 3. E o que para os outros é um consolo em qualquer desventura ou desgraça, orar aos deuses é para nós inútil, pois não podemos pedir aos deuses ao mesmo tempo a vitória para a pátria e a tua salvação, sendo que todas as maldiçóes lançadas sobre nós pelos nossos inimigos estão nas nossas súplicas. 4 . $\mathrm{Na}$ verdade, a tua mulher e os teus filhos têm de ficar sem ti ou sem pátria. 5. Eu não esperarei que a guerra decida por mim, comigo viva, esta sorte ${ }^{137}$. Leva isso em conta, se eu não te convencer a que ponhas a amizade e a concórdia <à frente> da maldade e da discórdia, tornando-te benfeitor de ambos os $\operatorname{lados}^{138}$, e não no destruidor de um ou de outro. Portanto, prepara-te para passares por cima do cadáver da que te gerou antes de conseguires tomar de assalto a pátria. 6. Pois não esperarei o dia em que veja o meu filho ser exibido no triunfo como cativo, pelos seus concidadãos, ou, pelo contrário, triunfante sobre a sua pátria. 7. Pedir-te que

136 Tyche.

137 Tyche.

138 Alguns autores entendem aqui «ambos os lados em conflito», enquanto outros consideram tratar-se de uma referência à «família e pátria». 
salves a tua pátria destruindo os Volscos, ó filho, seria pôr-te perante uma decisão difícil e entregar-te à dúvida, pois não está certo destruir os nossos concidadáos e não é justo trair os que confiaram em nós. 8. Por isso, o que agora te pedimos é que nos livres destes males, uma salvação igual para ambas as partes, mas que seja mais gloriosa e bela para os Volscos, pois sendo mais fortes parecerá que dão os bens mais importantes, a paz e a amizade, sem no entanto os receber de somenos. Se assim acontecer, o mérito será em primeiro lugar teu; se não acontecer, só tu serás o culpado perante ambas as partes. 9. A guerra é incerta, mas é certo que, se venceres, serás recordado como a desgraça da tua pátria, e se fores derrotado, serás aquele que por causa da ira causou grandes males aos homens que foram seus benfeitores e amigos.»

36. 1. Enquanto Volúmnia falava, Márcio ouvia sem nada contestar. E como mesmo depois de ela ter terminado ele permanecia em silêncio por muito tempo, Volúmnia voltou a dizer: 2. «Porque te manténs calado, filho? Será bom dar tanto à ira ou ao rancor e não agradar a uma mãe que te suplica por tanto? Ou será próprio de um grande homem recordar-se dos males que sofreu, enquanto a veneração e as honras devidas pelos filhos aos seus progenitores náo é digna da sua grandeza e bondade? Pois ninguém devia conservar maior gratidão do que tu, que com tanta amargura vais atrás da ingratidão. 3. E no entanto, se o castigo com que puniste a pátria foi grande, a tua mãe não recebeu nenhuma gratidão. 
Pois seria piedoso que, sem qualquer obrigação, eu de ti recebesse algo assim de táo belo e justo. Mas como náo te convenço, porquê prescindir da minha última esperança?» ${ }^{139} 4$. E dito isto, ela caiu de joelhos ao mesmo tempo que a mulher e os filhos dele. 5. "Que me fizeste tu, mãe?» gritou Márcio. Ele levantou-a, apertou fortemente a sua mão direita e disse: "Ganhaste! E esta é uma vitória afortunada para a pátria, mas fatal para mim, pois só por ti me vou daqui, derrotado.» 6. Dito isto e depois de uma pequena conversa privada com a mãe e a mulher, enviouas de volta para Roma, a pedido delas. Quando a noite se levantou, levou dali os Volscos, que não foram unânimes no modo e na forma como viram tudo isto. 7. Na verdade, uns censuravam o homem e a acção; outros nenhuma das coisas, pois eram adeptos de uma solução pacífica; e outros ainda, apesar de aborrecidos com o que se passara, não tinham Márcio como má pessoa, mas digno de perdão, por se ter deixado arrastar por tais imposiçóes. 8 . Mas ninguém se insurgiu e todos o seguiram, admirando mais a sua virtude do que a sua autoridade.

37. 1. O povo romano ${ }^{140}$ só percebeu melhor o medo e o perigo a que tinha estado sujeito durante a guerra quando esta acabou. 2. No preciso momento em que os que estavam nas muralhas viam os Volscos levantar o acampamento, já todos os templos se abriam e todos usavam as coroas da vitória e ofereciam sacrifícios. 3. Mas a alegria da cidade era visível sobretudo pelas

${ }^{139}$ Sobre o diálogo de Coriolano com a mãe, ver PÉrEz Jiménez (2006), 121, n. 165.

${ }^{140}$ Literalmente, lemos «o povo dos Romanos». 
grandes demonstraçóes de carinho e pelas honras que o senado e a multidão prestavam às mulheres, pois diziam e acreditavam que aquelas eram sem dúvida alguma as responsáveis pela salvação. 4. O senado decretou que os magistrados thes fizessem e outorgassem todas as honras e privilégios que pedissem, mas elas nada pediram como recompensa, a não ser a construção de um templo dedicado à Fortuna Feminina ${ }^{141}$, unindo-se elas próprias para a despesa. O serviço religioso e as honras devidas aos deuses, todavia, caberiam ao povo da cidade. 5 . O senado elogiou a sua conduta, mas ergueu a casa da deusa a custos públicos, assim como uma imagem sentada ${ }^{142}$.

${ }^{141}$ A Fortuna Muliebris era uma expressão do culto itálico da Fors Fortuna. Dizia-se que este culto havia sido introduzido em Roma por Sérvio Túlio, tal como o da Fors Virginalis e o da Fors Virilis. Estas eram manifestaçóes religiosas ligadas à sexualidade, em especial à sexualidade feminina. A este propósito, refira-se que o termo latino fortuna está etimologicamente ligado ao verbo fero (que pode significar também "produzir»), bem como a vocábulos como femina, felix e fecundus. No seguimento do que referimos na introdução, a Fortuna romana, senhora da fertilidade mas também do acaso, tinha uma conotação ambígua: tanto era caprichosa e volúvel como inequivocamente positiva. A Tyche grega aproximava-se mais do primeiro sentido. O templo à Fortuna Feminina foi erguido na Via Latina, no lugar onde supostamente Coriolano se havia encontrado com a sua mãe, a quatro milhas de Roma. Naturalmente, Plutarco usa, em grego, a forma Tyche gynaikeia, que corresponde a uma divindade grega/helenística entendida como o Acaso divinizado. Sobre este culto, ver J. Guillén, Vrbs Roma III - La religión y el ejército, Salamanca, 2001 ${ }^{4}$, 360; e ainda Plutarco, Acerca da Fortuna dos Romanos 318F-319A. Agradecemos ao Doutor Delfim F. Leão as sugestóes acerca da dialéctica Fortuna/Tyche.

${ }^{142}$ A Fortuna era representada com o corno da abundância, umas vezes sentada outras de pé, e quase sempre cega, enunciando deste modo a sua dupla natureza: ora positiva, ora negativa; ora promotora 
Com o dinheiro que elas juntaram, que não foi em quantidade inferior, fizeram uma segunda estátua, que, segundo dizem os Romanos, ao ser colocada no templo, proferiu as seguintes palavras: "Mulheres, é caro aos deuses o que me dedicastes.» ${ }^{143}$

38. 1. Diz-se que estas palavras se fizeram ouvir por duas vezes, para nos convencer de algo em que é difícil acreditar e que parece nunca ter acontecido. 2 . Com efeito, que uma estátua possa transpirar ou chorar ou até deixar cair um líquido parecido com sangue não é impossível; pois a madeira e as pedras criam muitas vezes uma substância que produz humidade e que faz com que apareçam cores ou se formem manchas, pelo contacto com a atmosfera, as quais, poderá pensar-se, a divindade poderia usar como sinais ou indícios de algo. 3. É também possível que uma estátua solte um ruído igual a um choro ou a um gemido, através de uma ruptura ou abertura nas suas partes, que se dá com mais força no interior. Mas é totalmente inconcebível que haja voz articulada e um discurso claro, elaborado e preciso em algo inanimado, visto que nem a alma nem sequer a divindade emitem qualquer ruído ou falam sem um corpo com órgãos específicos que lhes sirva de instrumento ${ }^{144}$. 4. Por isso, quando a história nos quer obrigar a acreditar citando muitas testemunhas, é porque

da abundância ora caprichosa na distribuição das suas benesses.

${ }^{143}$ História igualmente narrada em Dionísio de Halicarnasso, Antiguidades Romanas 8, 56.

${ }^{144}$ Talvez haja aqui uma alusáo à Pítia de Delfos, que transmitia os oráculos de Apolo. 
estamos perante um fenómeno distinto da percepção, que nasce na faculdade imaginativa da alma e nos faz acreditar naquilo que não passou de uma alucinação, tal como nos sonhos, em que pensamos ouvir, não ouvindo, e ver, não vendo. 5. De qualquer modo, para os que, por devoçáo e afecto, têm muita empatia para com a divindade e não renegam nem recusam estas possibilidades, o maravilhoso transcendente do poder divino torna-se importante para a sua fé ${ }^{145}$. 6. Pois em nada se assemelha ao que é humano, nem em natureza, nem em actividade, nem em capacidade, nem em força e não é sequer impossível que concretize algo de inconcretizável ou inexequível. Sendo diferente de nós em todos os aspectos, é sobretudo pelas suas obras que a divindade se distingue. 7. Mas, segundo Heraclito, muitas das coisas divinas escapam ao nosso conhecimento por falta de fé146.

39. 1. Quanto a Márcio, quando regressou a Âncio depois da campanha, Tulo, que há muito tempo o odiava e que por inveja já náo o suportava mais, conspirou para se livrar dele de imediato. Pois se escapasse agora náo haveria outra ocasião. 2. Depois de ter reunido muitos e de os indispor contra ele, desafiou-o a prestar contas e a submeter-se aos Volscos, renunciando ao poder. 3. Ele teve medo de se tornar um homem comum,

145 Note-se como a explicação de Plutarco aponta num sentido racionalizante do fenómeno.

${ }^{146}$ Heraclito, frg. 86 Diels-Kranz. Neste parágrafo encontramos algumas das questốes mais pertinentes para estudar a religiosidade de Plutarco. 
enquanto Tulo era um general com grande autoridade entre os seus concidadãos. Disse então que devolveria o poder aos Volscos se estes tho exigissem, pois havia-o tomado por vontade de todos. Mas que também náo se negaria, desde agora, a prestar contas aos Anciates que o desejassem. 4. Quando a assembleia se reuniu, os demagogos subornados levantaram-se para incitar a multidão. 5. Mas no momento em que Márcio se pôs de pé, o respeito que causava impôs-se, o ruído parou e ele pôde falar com tranquilidade. Entre os Anciates, os melhores e os mais satisfeitos com a paz mostraram que o ouviriam de boa-vontade e que o julgariam com justiça. Mas Tulo temeu a defesa do homem. 6. É que ele era um dos oradores mais temíveis e a gratidão pelos seus feitos anteriores superava as razóes posteriores. $\mathrm{Ou}$ melhor, tudo o que lhe era censurado testemunhava o enorme reconhecimento que lhe era conferido. 7. Pois não se sentiriam defraudados por náo terem conquistado Roma, se não tivessem estado próximos disso graças a Márcio. 8. Por isso, resolveram não deixar passar mais tempo nem conhecer a opiniáo da multidão. Os mais arrogantes dos conjurados, porém, começaram a gritar que os Volscos não tinham de ouvir nem de ver um traidor que os tiranizava e que não largava o poder, pelo que, a multidão, caindo sobre ele, assassinou-o, sem que nenhum dos presentes fosse em sua ajuda ${ }^{147}$. 9. A maioria, contudo, não aprovou o que aconteceu e logo o mostrou, quando começou a afluir gente vinda das suas

${ }^{147}$ Segundo Dionísio de Halicarnasso, Antiguidades Romanas 8, 5, Coriolano foi apedrejado. Tito Lívio 2, 40, inclui também a versão segundo a qual Coriolano teria morrido de velhice. 
cidades para honrar o corpo, que sepultaram adornado com armas e despojos, tal como é devido aos melhores e a um general. 10. Quando os Romanos souberam da sua morte, não a assinalaram nem com honras nem com ira contra ele, mas, a pedido das mulheres, permitiram-lhes o luto por dez meses, como era hábito elas guardarem pelo pai ou por um filho ou por um irmáo. 11. Pois era este o limite máximo que Numa Pompílio determinou para o luto, tal como expusemos quando escrevemos sobre ele $^{148}$. 12. Entre os Volscos, os problemas fizeram com que se sentisse de imediato a falta de Márcio. Primeiro, devido a um conflito com os Équos ${ }^{149}$, que eram seus aliados e amigos. Por causa da hegemonia, acabaram em golpes e massacres. Logo a seguir, foram vencidos em batalha pelos Romanos ${ }^{150}$. Nela morreu Tulo e foi destruída a fina-flor das suas tropas. Acabaram por ter de se resignar com as humilhaçōes a que foram sujeitos: tornaram-se súbditos romanos e foram forçados a fazer tudo aquilo que lhes foi ordenado.

${ }_{148}$ Plutarco, Numa Pompilio 12, 3.

149 Sobre este povo itálico e suas relaçóes com os Volscos, ver Cornell (1995) 304-309.

${ }^{150}$ Batalha de Velitras, que ocorreu em 487 a.C., com a campanha de Tito Sicínio. O domínio definitivo dos Volscos concretizou-se em 486 a.C., com o cônsul Espúrio Cássio. Ver Cornell (1995) 293-326. 
(Página deixada propositadamente em branco) 


\section{COMPARAÇÁO ENTRE AlCibÍADES E CORIOLANO**}


(Página deixada propositadamente em branco) 
40. 1. Uma vez expostas aquelas acçôes dos dois biografados, que consideramos dignas de ser mencionadas e lembradas, pode verificar-se que os seus feitos na guerra não fazem inclinar a balança para um ou outro lado. 2. De facto, ambos se distinguiram, de modo idêntico, como soldados, pelos muitos actos de audácia e coragem praticados e, como generais, pela sua perícia e capacidade de previsão - a não ser que se queira ver em Alcibíades um estratego mais completo, pelo facto de ter conseguido alcançar continuamente vitórias e êxitos em muito mais combates em terra e no mar. De qualquer modo, conduziram sempre, com êxito evidente, os assuntos das respectivas pátrias, enquanto nelas permaneceram e aí exerceram o poder; em contrapartida, foi mais que evidente o prejuízo que cada um causou à sua, quando se passou para o campo do adversário. 3. No que diz respeito à conduta política de cada um, se a de Alcibíades, no seu arrojo não isento de grosseria e vulgaridade, com o objectivo de alcançar o favor da multidão, desagradava aos homens sensatos, a de Márcio, por seu turno, de todo impopular, sobranceira e oligárquica, ganhou o ódio do povo romano. 4. Sendo assim, nem uma nem outra são dignas de louvor; contudo, aquele que cultiva a demagogia e procura agradar ao povo é menos digno de censura que aquele que, para não ser confundido com 
um demagogo, trata o povo com desprezo. É que, se é vergonhoso adulá-lo tendo em vista o poder, assentar a força no medo, na perseguição e na opressão é, para além de uma vergonha, também uma injustiça.

41. 1. Que Márcio passe por ter sido uma pessoa de carácter simples e directo, e Alcibíades um homem sem escrúpulos na política e sem franqueza, não há que ter dúvidas. 2. É reprovada, em especial, a perversidade e falsidade de que usou com os embaixadores dos Lacedemónios, como relata Tucídides, para quebrar a paz. 3. Foi, contudo, essa mesma política, apesar de ter sido responsável por lançar de novo a cidade para a guerra, que a tornou forte e temível, com a aliança com Mantineia e Argos, conseguida graças a Alcibíades. 4. Márcio, por seu turno, também provocou, com recurso ao dolo, a guerra entre Romanos e Volscos, levantando acusaçóes caluniosas contra os que tinham vindo para assistir os jogos, segundo o conta Dionísio. Ora o motivo da sua acção torna-a mais reprovável. 5. É que não foi por ambição, nem em consequência de uma luta ou rivalidade política, como no caso de Alcibíades, mas para saciar a sua cólera - paixão que, como afirma Díon, nunca trouxe a ninguém grata compensação - que ele suscitou agitação em muitas regióes da Itália e levou à ruína muitas cidades que não haviam contribuído com qualquer espécie de razão para o rancor que ele alimentava contra a pátria. 6. É um facto que também Alcibíades foi responsável por grandes males acontecidos à sua pátria, na sequência da sua cólera; este, no entanto, 
logo que deu conta do arrependimento dos Atenienses, deixou-se tomar por sentimentos favoráveis e quando, de novo, o expulsaram da pátria, não se encheu de júbilo com os erros cometidos pelos estrategos nem deixou de se preocupar com as decisóes desastrosas e os perigos a que se expunham. Pelo contrário - procedeu de modo idêntico ao de Aristides e que tantos elogios valeram a este, quando se avistou com Temístocles: dirigiu-se aos homens que detinham, então, o poder, ainda que não fossem seus amigos, e indicou-lhes e explicou-lhes o que haviam de fazer. 7. Márcio, em contrapartida, começou, antes de mais, por fazer mal a toda a cidade, apesar de não ter razão de queixa de todos os cidadáos e apesar de parte deles - a mais nobre e mais poderosa - ter sido igualmente maltratada e sujeita aos mesmos padecimentos. Em segundo lugar, na medida em que permaneceu insensível e inabalável perante as muitas embaixadas e súplicas com que os seus concidadãos tentavam aplacar a cólera e a insensatez de um só homem, Márcio tornou evidente que tinha empreendido uma guerra cruel e implacável, unicamente para destruir e arrasar a sua pátria, não para a recuperar e a ela regressar. 8. Poderá dizer-se que existe, entre ambos, esta diferença: Alcibíades voltou a passar-se para o lado dos Atenienses dado que os Espartanos, devido ao medo e ao ódio que por ele nutriam, planeavam armar-lhe uma cilada, enquanto para Márcio náo era correcto abandonar os Volscos, que o tratavam com toda a lealdade. 9. Em boa verdade, tinham-no nomeado general e ele contava com a sua confiança, para além do poder que deles 
recebera. Não foi esse o caso de Alcibíades, de quem os Lacedemónios abusavam, mais do que usavam, e que andou sem rumo na cidade destes, para depois se ver atirado para o seu acampamento e, por fim, ir cair nas mãos de Tissafernes - a menos que, por Zeus!, lisonjeasse o Persa para evitar a destruição total de Atenas, a que ansiava regressar.

42. 1. No que toca a dinheiro, conta-se que Alcibíades muitas vezes o recebeu, de forma ilícita, das mãos de quem o pretendia subornar e que o utilizou de forma imprópria, para o seu luxo e os seus excessos, ao passo que os generais não conseguiram persuadir Márcio a aceitar quantia alguma como prémio do seu valor. 2 . Precisamente por isso atraiu sobre si o ódio da multidão, nas querelas com o povo por causa das dívidas, pois o povo estava convencido que ele não humilhava os pobres tendo em vista obter proveitos, mas por insolência e desprezo. 3. Antípatro, numa carta em que se referia à morte do filósofo Aristóteles, diz: "Além de outras capacidades, este homem possuía também o dom da persuasão". Ora foi por falta deste dom que as acçóes e virtudes de Márcio se tornaram odiosas, inclusivamente para aqueles que delas beneficiaram, pois não puderam suportar o seu orgulho e a sua arrogância, "companheira da solidão", consoante Platão o diz. 4. Alcibíades, pelo contrário, sabia tratar com afabilidade quantos se acercavam dele. E, assim, não era de admirar que, nos seus êxitos, o seu renome florescesse, acompanhado de simpatia e honras, pois alguns dos seus erros chegaram, 
com frequência, a gozar de popularidade e favor. 5. Por isso, apesar dos prejuízos não raros nem pequenos que ele causou à sua cidade, foi, ainda assim, muitas vezes indigitado para a seu governante e seu estratego, ao passo que Márcio viu fracassar as suas apiraçóes a uma magistratura a que tinha direito pelas suas façanhas e pela sua bravura. 6. Deste modo, o primeiro não foi objecto de ódio dos seus concidadáos, apesar de lhes ter causado dissabores, enquanto o segundo, ainda que admirado, não conseguiu fazer-se amar.

43. 1. É que de facto Márcio não trouxe êxito algum à cidade, enquanto general, mas proporcionou-o aos inimigos, em campanhas contra a pátria. Os Atenienses, em contrapartida, colheram proveitos das numerosas campanhas militares em que Alcibíades tomou parte, quer como mero combatente, quer como general. Quando se encontrava em Atenas, dominava os inimigos consoante era sua vontade e as calúnias contra a sua pessoa só ganhavam força quando se encontrava fora. 2. Márcio, pelo contrário, estava em Roma quando os Romanos o condenaram e entre os Volscos quando estes o mataram. Tratou-se de um acto injusto e ímpio, mas para o qual ele mesmo forneceu um motivo com fundamento, pois não aceitou as ofertas públicas de reconciliação, mas prestou ouvidos, em privado, às mulheres e não pôs, assim, termo às hostilidades entre os dois povos. Ao deixar que a guerra perdurasse, perdeu e pôs fim à oportunidade de estabelecer a paz. 3. Com efeito, ele só se devia ter retirado depois de ter obtido 
a concordância dos que haviam depositado confiança nele, se tivesse tido em consideração todas as suas obrigaçóes para com eles. 4. Mas se não se preocupava minimamente com os Volscos, provocando uma guerra para saciar os seus desejos pessoais de vingança, para, de seguida, a interromper, a atitude correcta não teria sido perdoar a pátria por causa de sua mãe, mas perdoar a máe com a pátria, pois a sua mãe e a sua mulher faziam parte da pátria que ele tinha sob cerco. 5. Ora o facto de, após ter repudiado, com dureza, as súplicas oficiais, os apelos dos emissários, as preces dos sacerdotes, se retirar, como um favor feito a sua mãe, não constituiu manifestação de respeito para com ela, mas um gesto de desrespeito em relação à pátria, salva por acção das lágrimas e rogos de uma só mulher, como se a pátria não fosse digna de se salvar por si mesma. 6. Tal favor tornou-se, em boa verdade, odioso, cruel e indigno de agradecimentos. Náo suscitou sentimentos de gratidão e não teve o aplauso de nenhuma das duas facçóes, pois Márcio retirou-se sem se ter deixado persuadir por aqueles contra quem movia guerra e sem persuadir aqueles que a moviam com ele. 7 . A causa de tudo isto foi o seu carácter insociável, arrogante e intransigente ao extremo - carácter que, já por si, se tornava execrável para a multidão mas que, aliado à ambição, chegava a tornarse selvagem e inexorável. 8 . Homens assim náo tratam de adular multidão, como se não sentissem necessidade de honrarias, mas logo se amofinam por não as obter. É um facto que Metelo, Aristides, ou Epaminondas cultivavam essa atitude de não condescenderem perante a multidão 
nem a adularem, mas porque desprezavam, na realidade, aquilo que o povo é mestre em conceder ou retirar. Pese embora terem sido condenados ao ostracismo, vencidos em eleiçôes, condenados, com frequência, por tribunais, não se deixaram tomar pelo rancor contra os seus concidadãos - pelo contrário, dispensavam-lhes o seu afecto quando aqueles se arrependiam e com eles se reconciliavam, uma vez chamados de novo para a comunidade. 9. Justamente, quem é menos dado a adular a multidão, menos vingativo deve ser para com ela, já que, se alguém se encoleriza intensamente por não obter honrarias, isso significa que com intensidade as deseja.

44. 1. Ora Alcibíades não negava o quanto the dava prazer receber honras e tolerava mal ver-se posto à margem. Por isso procurava agradar aos que o cercavam e tornar-se insinuante. A Márcio, porém, o orgulho não lhe permitia recorrer à adulaçáo junto de quem lhe podia conceder honrarias e engrandecê-lo, mas a sua ambição causava-lhe aborrecimento e dor quando o ignoravam. 2. Eis o que se pode censurar neste homem, que em tudo o mais foi brilhante. Pela sua temperança e autodomínio perante a riqueza é digno de ser comparado aos mais nobres e mais puros de entre os Gregos - mas não, por Zeus!, a Alcibíades, que foi, nesta matéria, o homem mais destituído de pudor e mais indiferente a questóes de honra. 
(Página deixada propositadamente em branco) 


\section{BibLIOGRAFIA}

\section{EDIÇÔES, TRADUÇÓES E COMENTÁRIOS}

Bravo García, A. (int.) e Ozaeta Gálvez, Ma (trad.): Plutarco. Vidas Paralelas. Alcibiades-Coriolano, Sertorio-Eumenes (Madrid, Alianza Editorial, 1998).

Crespo, E.: Plutarco. Vidas Paralelas. Alejandro-César, Pericles-Fábio Máximo, Alcibiades-Coriolano (Madrid, Cátedra, 2003²).

Flacelière, R. (trad.), Chambry, É. (trad.), Mossé, C. (int., not.): Plutarque. Les Vies Parallèles. AlcibiadeCoriolan (Paris, Les Belles Lettres, 1999).

— (trad.), Chambry, É. (trad.), Sirinelli, J. (pres.): Plutarque. Vies Parallèles I (Paris, Robert Laffont, 2001).

— Chambry, É.: Plutarque. Vies. Périclès-Fabius Maximus, Alcibiade-Coriolan (Paris, Les Belles Lettres, 1964).

Manfredini, M., Musti, D.: Plutarco. Le vite di Alcibiade e di Coriolano (Milano, Lorenzo Valla, 1983).

Mossé, C., Flacelière, R., Chambry, É.: Plutarque. Vies. Alcibiade-Coriolan (Paris, Les Belles Lettres, 2002).

Pérez Jiménez, A. e Ortiz, P.: Plutarco. Vidas Paralelas III. Coriolano-Alcibiades, Paulo Emilio-Timoleón, Pelópidas-Marcelo (Madrid, Gredos, 2006). 
Perrin, B.: Plutarch's Lives. Alcibiades and Coriolanus, Lysander and Sulla (Harvard, University Press, 1968).

Ziegler, K.: Plutarchi Vitae Parallelae (Leipzig, Teubner, 1959).

\section{Estudos}

Becchi, F.: "Plutarco fra platonismo e aristotelismo: la filosofia comme paideia dell'anima”, in A. Pérez Jiménez, J. Garcia López, R. M. Aguilar, eds., Plutarco, Platón y Aristóteles. Actas del V Congreso Internacional de la I.P.S. (Madrid, Ed. Clásicas, 1999) 25-43.

Bonjour, M.: "Les personnages féminins et la terre natale dans l'épisode de Coriolan (Liv. 2, 40)", REL 53 (1975) 157-181.

Burkert, W.: Ancient Mystery Cults (Harvard, Cambridge, London, Harvard Univ. Press, 1987).

Calvo Martínez, J. L.: "Oratoria y biografía. El retrato de Alcibíades en Lísias e Isócrates”, in: A. Pérez Jiménez, J. Ribeiro Ferreira, M. C. Fialho, eds., $O$ retrato e a biografia como estratégia de teorização política (Coimbra/Málaga, Univ. de Coimbra, Univ. de Málaga, 2004) 37-48.

Cerezo Magán, M.: "Embriaguez y vida disoluta en las 
Vidas”, in J. G. Montes Cala, M. Sánchez Ortíz de Landaluce, R. Gallé Cejudo, eds., Plutarco, Dioniso y el vino. Actas del VI simposio español sobre Plutarco (Madrid, Ed. Clásicas, 1999) 171-180.

Cornell, T. J.: The Beginnings of Rome. Italy and Rome from the Bronze Age to the Punic Wars (c. 1000-264 $B C$ ) (London/New York, Routledge, 1995).

Duff, T.: "Plutarch on the Childhood of Alkibiades (Alk. 2-3)", PCPS 49 (2003) 89-117.

"The Structure of the Coriolanus-Alcibiades", in J. A. Fernández Delgado, F. Pordomingo Pardo, eds., Estudios sobre Plutarco: Aspectos Formales. Actas del IV Simposio Español sobre Plutarco (Salamanca, Universidad de Salamanca, 1996) 333-349.

_- Plutarch's Lives: Exploring Virtue and Vice (Oxford, 1999).

Erbse, H.: "Die Bedeutung der Synkrisis in den Parallelbiographien Plutarchs” Hermes 84 (1957) 398-424.

Ferreira, J. R.: "Próxeno e proxenia", in D. Leão, L. Rossetti, M. C. Fialho, eds., Nomos. Direito e sociedade na Antiguidade Clássica/Derecho y sociedad en la Antigüedad Clásica (Coimbral Madrid, Imprensa da Universidade de Coimbra, Ediciones Clásicas, 2004) 227-239. 
Fialho, M. C.: "From Flower to Chamaleon. Values and Counter-Values in Alcibiades' Life", in J. Ribeiro Ferreira, L. Van Der Stock, M. C. Fialho, Philosophy in Society. Virtues and Values in Plutarch (Leuven/Coimbra, Katholieke Universiteit Leuven, Imprensa da Universidade de Coimbra, 2008) $107-116$.

Frazier, F.: "Contribution à l'étude de la composition des 'Vies? De Plutarque: l'élaboration des grandes scènes", $A N R W$ II.33.6 (1992) 4488-4535.

_- Morale et histoire dans les Vies Parallèles de Plutarque (Paris, Les Belles Lettres, 1996).

__ “À propôs de la philotimie dans les Vies. Quelques jalons dans l'histoire d'une notion" RPh 67 (1988) 109-127.

Freyburger, M.-L.: "Coriolan, ou la construction littéraire d'un grand homme chez les historiens grecs de Rome", in M. Coudry, T. Späth, eds., L'Invention des Grands Hommes de la Rome Antique (Paris, 2001) 27-46.

Geiger, J.: "Plutarch's Parallel Lives: The Choice of Heroes", Hermes 109/1 (1981) 85-104.

Hershbell, J. P.:"Plutarch's Portrait of Socrates" ICS 13 (1988) 365-382.

LACY, P. de: "Biography and Tragedy in Plutarch", $A J P h$ 73/2 (1952) 159-171. 
Lehman, A. D.: "The Coriolanus Story in Antiquity", CJ 47/8 (1952) 329-336.

Löв, L., Lerner, L.: "Views of Roman History: Coriolanus and Coriolan", Comparative Literature 29/1 (1977), 35-53.

Mayer, K. I.: Cultural Renegades in Plutarch's Lives (Austin, The University of Texas, 1997).

Nerdahl, M., Homeric Models in Plutarch's Lives (Madison, University of Wisconsin, 2007).

Pelling, C. B. R.: "Plutarch's Method of Work in the Roman Lives", JHS 99 (1979) 74-96.

_ "Plutarch's Adaptation of his Source-Material", JHS 100 (1980) 127-140.

— "The Shaping of Coriolanus: Dionysius, Plutarch, and Shakespeare", Poetica 48 (1997) 3-32.

- Plutarch and History: Eighteen Studies (Wales, 2002).

Pérez Jiménez, A.: “Actitudes de l'hombre frente a la tyche en las Vidas Paralelas de Plutarco" BIEH 7 (1973) 101-110.

Pinheiro, J. J. S.: "O sentido de philanthropia nas biografias de Coriolano, Cícero e Catão de Útica”, in J. R. Ferreira et al., Symposion and Philanthropia in Plutarch (Coimbra, Centro de Estudos Clássicos e Humanísticos da Universidade de Coimbra, 2009) 359-366. 
Rodrigues, N. S.: "História, Filologia e Problemáticas da Antiguidade Clássica”, in M.F. Reis, coord., Rumose Escrita da História. Estudos em Homenagem a A.A. Marques de Almeida (Lisboa, Edições Colibri, 2007) 643-659.

- Mitos e Lendas da Roma Antiga (Lisboa, Livros e Livros, 2005).

Romilly, J. DE, Alcibiade ou Les dangers de l'ambition (Paris, Éditions de Fallois, 1997).

Russell, D. A.: "Plutarch's Life of Coriolanus", JRS 53/1-2 (1963) 21-28.

Salmon, E. T.: "Historical Elements in the Story of Coriolanus", CQ 24/2 (1930) 96101.

Salvioni, L.: "Le madri dell'ira nelle Vite di Plutraco", GFF 5 (1982) 83-92.

Simonds, P.: "Coriolanus and the Myth of Juno and Mars”, Mosaic 18 (1985) 33-50.

Smith, R. E.: "Plutarch's Biographical Sources in the Roman Lives", CQ 34/1-2 (1940) 1-10.

Stadter, Ph.: "The Proems of Plutarch's Lives" ICS 13 (1988) 275-295.

Swain, S. C. R.: "Plutarch: Chance, Providence, and History”, AJPh 110/2 (1989) 272302.

_ "Hellenic Culture and the Roman Heroes of Plutarch", JHS 110 (1990) 126-145. 
__ "Plutarchan Synkrisis" Eranos 90 (1992) 101111.

Titchener, F. B.: "Critical Trends in Plutarch's Roman Lives, 1975-1990”, ANRW II.33.6 (1992) 41284153.

Vickers, M.: Sophocles and Alcibiades: Athenian Politics in Ancient Greek Literature (Stochsfield, Acumen, 2008).

Walbank, F.: “Tragedy and History”, Historia 9 (1960) 216-234. 
(Página deixada propositadamente em branco) 


\section{ÍNDICE DE NOMES}

Aвidos: AlC. 27.3; 29.4; 36.2

Adimanto: ALC. 36.6

Adónis: ALC. 18.5

Agatarco: Alc. 16.5

ÁgIs: ALC. 23.7; 23.8; 24.3; 25.1; 34.5; 38.6

Agraulo: Alc. 15.7

Agrila: ALC. 22.5

Agripa, Menénio: COR. 6.3

ÁJAX: ALC. 1.1

Alcibíades: AlC. passim

AlCMEÓnida: ALC. 1.1

AMicLA: ALC. 1.3

AMOR: ALC. 16.1

Anaxilau: AlC. $31.3 ; 31.7$

AnCiates: COR 9.6; 13.5; 19.1; 20.5; 39.3; 39.5

ÂNCIO: COR. 22.1; 26.1; 39.1

ANDÓcides: ALC. 21.1; 21.3; 21.4; 21.5; 21.6

ÂNDROCles: ALC. 19.1; 19.3

Andros: ALC. 35.2

ÂNIO: COR 6.1

ÂNito: $A L C .4 .4 ; 4.5$; Cor. 14.6

Antémion: ALC. 4.4; COR 14.6

Antifonte: ALC. 3.1

Antígono de Cirene: Cor 11.3

Antíoco: AlC. 10.2; 35.6; 35.7

Antípatro: COMP. ALC. COR. 42.3

Antístenes: ALC. 1.3

Apolo: ALC. 2.6

Aquiles: ALC. 23.6

ArCÁdios: COR 3.3

ARCIPo: ALC. 1.8

Argivos: AlC. $12.3 ; 14.3$

Argos: AlC. 12.3; 15.1; 15.3; 19.4; 23.1; COMP. ALC. COR 41.3

Arífron: ALC. 1.2; ALC. 3.1

Aristides: COMP. ALC. COR. 41.6; 43.8

Aristófanes: ALC. $1.7 ; 16.2 ; 16.3$

Aristofonte: ALC. 16.7

Aristóteles: COMP. AlC. COR 42.3

ArquÉstrato: AlC. 16.8 
ArtaxerXes: Alc. 37.7

Artemísio: ALC. 1.1

ÁsIA: ALC. 37.7

Aspendos: ALC. 26.8

Astíoco: ALC. 25.7; 25.8; 25.10; 25.11

Atena: Alc. 2.6; [34.1; 34.2]; COR 32.4

AtenAs: ALC. $12.3 ; 14.12 ; 14.3 ; 15.2 ; 15.5 ; 24.1 ; 24.2 ; 25.2 ; 26.1 ; 26.6$; 27.1;31.3;31.6; 36.1; 37.5; 38.1; 38.5; COR 14.6; COMP. ALC. COR 41.9; 43.1

Atenienses: ALC. $14.3 ; 14.4 ; 14.5 ; 14.9 ; 15.1 ; 15.6 ; 15.7 ; 16.4 ; 17.1$; $17.4 ; 7.3 ; 7.6 ; 9.2 ; 10.2 ; 18.1 ; 18.7 ; 20.3 ; 23.2 ; 24.1 ; 25.1 ; 25.2$; $25.3 ; 25.5 ; 25.10 ; 25.11 ; 25.12 ; 25.13 ; 25.14 ; 26.5 ; 27.2 ; 27.4 ; 27.6$; 28,$2 ; 28.4 ; 28.9 ; 29.2 ; 30.1 ; 30.7 ; 31.1 ; 31.4 ; 32.2 ; 34.2 ; 35.3 ; 35.7$; 36.4; 36.6; 37.4; 38.5; COMP. ALC. COR 41.6; 41.8; 43.1

Ática: ALC. 15.8

Átio, Tulo: COR 22.1; 23.1; 23.2; 23.9; 26.1; 26.4; 26.6; 27.1; 28.1; $28.2 ; 31.3 ; 39.1 ; 39.3 ; 39.5 ; 39.12$

BAgEU: AlC. 39.1; 39.3

BÁrbaros: AlC. 36.5; 39.5; 39.7

BATO II: COR. 11.2

Beócios: ALC. $1.1 ; 14.4 ; 14.5 ; 24.1 ; 31.4 ; 31.8$

Bisante: ALC. 36.3

Bitínia: ALC. 37.6; 37.7

Bitínios: ALC. 29.6

BizÂNCio: ALC. $31.3 ; 31.4 ; 31.8$

Bizantinos: AlC. 31.3; 31.6; 31.8

BOILA: COR 29.1

BOLANOS: COR. 28.5

Bruto, Júnio: COR. 7.2; 13.1

CalcÉdon: AlC. 30.1; 31.1

Calcedónios: AlC. 29.6; 31.1

Calescro: Alc. 33.1

CÁlias: AlC. 8.1; 8.3; 8.4

Calínico: COR. 11.2

Calípides: AlC. 32.2

CÁRIA: ALC. 35.5

Cartago: Alc. $17.3 ; 17.4$

Catana: Alc. 20.3

Catâo-o-Censor: ver Pórcio Catão-o-Censor, Marco

Cenco: COR 11.6

CÉLERE: COR 11.4 
Censorino: ver Márcio Rutílio Censorino, Gaio

CÉRICES: ALC. 22.4; 33.3; 34.6

Címon: ALC. 19.3; 22.4

Circeu: Cor 28.3

Ciro: Alc. 35.5

Cízico: ALC. 24.1; 28.2; 28.5; 28.9

Cláudio, Ápio: COR 19.3

Clazómenas: Alc. 28.1

Cleantes: Alc. 6.2

Clínias: AlC. 1.1; 11.3; 22.4

Clódio: COR 11.6

Cnidos: AlC. 27.2

Comínio, Póstumo: CoR 8.1; 8.2; 9.6; 11.1

Cónon: ALC. 37.4

Coníntios: AlC. 14.5; 18.7

Coriolano: COR 11.1; 11.2; 23.4; passim; ver Márcio Coriolano, Gaio

Coriolanos: COR. 8.1; 8.2

Coroneia: AlC. 1.1

Cós: ALC. 27.2

Crisógono: AlC. 32.2

CRÍtias: Alc. $33.1 ; 38.5$

Decelia: Alc. 23.2; 34.4

DÉLION: ALC. 7.6

Demócrates: ALC. $3.1 ; 1.3$

Demóstrato: ALC. 18.3

Diadémato: COR 11.4

Dinómaca: ALC. 1.1

Dioclides: ALC. 20.7; ALC. 20.6

Diomedes: ALC. 12.3

DíON: COMP. ALC. COR. 41.5

Dionísio: COMP. ALC. COR 41.4

Dioscuros: COR. 3.5

Diradiotas: Alc. 25.6

Dóson: COR. 11.3

DúRIS: ALC. 32.2

EfÉsIOs: ALC. 12.1

Éfeso: ALC. 35.6; 8.6; 29.2

Éforo: ALC. 32.2

EgIDAS: $A L C .21 .2$

Egospótamos: ALC. 36.6

ElÊUSIS: ALC. 22.4; 34.4; VER MisTÉRIOS DE ElÊUSIS 
ÉLIDE: ALC. 15.1

ENEIAS: COR. 29.2

Epaminondas: COR. 4.6; COMP. AlC. COR. 43.8

ÉQuOS: COR. 39.12

Erasístrato: Alc. 13.1

EsCAmbónides: ALC. 22.4

EsfaCtÉRIA: ALC. 14.4

Esparta: ALC. $23.5 ; 24.1 ; 24.4 ; 31.8 ; 38.6$

Espartanos: AlC. $14.3 ; 23.1 ; 23.2 ; 24.1 ; 24.3 ; 25.1 ;$ COMP. AlC. COR 41.8

EsTíRIA: 26.6

EUDÉMON: COR 11.2

EumólPidAs: ALC. 22.4; 33.3; 34.6

Êupolis: ALC. 13.2

EURÍPIDES: ALC. $1.5 ; 11.3$

Euriptólemo: ALC. 32.2

EURÍSACES: ALC. 1.1

EVÉRgETA: COR 11.2

FARNÁBAZO: ALC. $24.1 ; 27.5 ; 28.8 ; 28.9 ; 29.4 ; 29.5 ; 30.1 ; 30.2 ; 31.1$; $31.2 ; 37.8 ; 39.1 ; 39.9$

FÉAX: ALC. $13.1 ; 13.3 ; 13.8$

Fegeia: AlC. 22.4

Filadelfo: COR 11.2

FÍSCON: COR 11.2

FóRMION: ALC. 1.3

Fortuna Feminina: COR. 37.4

Fortuna: COR. 8.5; 24.6; 32.4; 35.2

Fossas CluÍlIas: COR 30.1

FrígIA: ALC. 37.8; 39.1

Frínico: ALC. 20.6; 25.6; 25.8; 25.9; 25.11; 25.12; 25.13; 25.14

GAIO: COR 11.2

GÉLON: COR 16.1

Gilipo: ALC. 23.2

GRÉCIA: $A L C .23 .2$

Gregos: AlC. 6.4; 14.2; 14.5; 24.6; 26.8; 36.5; COR. 11.2; 16.5; COMP. ALC. COR 44.2

GrIPO: COR 11.2

HÉLADE: ALC. $16.8 ; 38.5$

HeLÂNico: ALC. 21.1

Helenos: COR 24.10

Helesponto: AlC. $26.5 ; 27.2 ; 28.9 ; 30.3$

Heraclito: COR 38.7 
Hermes: AlC. 18.6; 20.5; 20.7; 21.2; 21.3

Hermocópidas: ALC. 20.8; 21.7

HÉRMON: ALC. 25.14

Hícara: ALC. 39.8

HipÁRETA: AlC. 8.3; 8.4

Hipérbolo: ALC. 13.4; 13.7; 13.8; 13.9

Hipócrates: ALC. $30.1 ; 30.2$

Hiponico: ALC. 8.1; 8.2; 8.3

Homero: ALC. 7.1; 7.2; 32.4; 32.6

Hostílio, Túlio: COR 1.1

Iónia: $A L C .23 .5 ; 24.2 ; 24.4 ; 26.5 ; 31.3 ; 35.3 ; 36.2$

IsÓCRATES: ALC. 12.3

Itália: AlC. 17.3; 20.2; COR. 6.1; 29.1; COMP. AlC. COR 41.5

ITÁLICOS: COR 3.1

Jogos Olímpicos: ALC. 11.1

Júpiter Capitolino: Cor 33.1

JÚPITER: COR. 24.3

LABICOS: COR. 28.5

LACEDEMónia: ALC. $14.6 ; 15.2 ; 23.6 ; 23.8 ; 24.2 ; 31.7$

LACEDEMÓNIOS: ALC. $14.1 ; 14.3 ; 14.4 ; 14.5 ; 14.9 ; 15.1 ; 15.2 ; 15.3 ; 15.6$; $24.4 ; 25.2 ; 26.2 ; 26.7 ; 26.8 ; 27.7 ; 31.8 ; 35.2 ; 35.5 ; 37.2 ; 37.6 ; 38.3$; 38.5; 38.6; COMP. ALC. COR. 41.2; 41.9

LAÍs: ALC. 39.8

LÂMACO: ALC. $1.3 ; 18.2 ; 21.9$

LAQUíAdes: ALC. 22.4

LÁrCio, Tito: COR 8.2; 8.6; 10.1; 10.2

Latínio, Tito: COR 24.2; 25.1

LATINOS: COR $3.1 ; 28.4 ; 28.5 ; 30.7$

Látiro: COR 11.3; Ver Ptolemeu Látiro

LAVÍNIO: COR. 29.2

LeOTÍQUidAS: ALC. 23.7; 23.9

LÉSBIOs: ALC. $12.1 ; 24.1$

Lesbos: ALC. 24.1

LEUCTRAS: COR 4.6

Líbia: ALC. $17.3 ; 17.4$

LicURgo: ALC. 23.6

LisANDRo: AlC. $35.5 ; 35.7 ; 35.8 ; 37.4 ; 37.5 ; 38.1 ; 38.5 ; 38.6 ; 39.1 ; 39.9$

Mantineia: AlC. $15.1 ; 15.2 ; 19.4 ;$ COMP. ALC. COR. 41.3

Márcio Coriolano, Gaio: Cor passim; ver Coriolano

Márcio Rutílio Censorino, Gaio: Cor 1.1

MÁrCIo, ANCO: COR. 1.1 
Márcio, Públio: COR 1.1

Márcio, Quinto: COR 1.1

Márcio: COR 11.2; VER Coriolano

MÁrcios: COR 1.1

MÉgaCles: AlC. 1.1

Megarenses: ALC. 31.4

MÉLIOS: ALC. 16.6

Melos: AlC. 16.5

Menandro: AlC. 36.6

MÉnOn: ALC. 22.5

Messina: ALC. 22.1

Metelo: COMP. Alc. COR. 43.8

Metelos: COR 11.4

MÉTON: ALC. 17.5; 17.6

Mídias: ALC. 10.3

Mileto: AlC. 23.3

Míndaro: AlC. 27.2; 28.2; 28.8; 28.10

Mistérios de ElÊUSIS: ALC. 19.1; 19.2; 20.5; 22.4; 34.3, VER ELÊUSIS

Monte Sagrado: COR 6.1

MuSAS: COR. 1.5

Nemeia: ALC. 16.7

NicÉrato: AlC. 13.1

NícIAs: ALC. $1.3 ; 13.1 ; 13.7 ; 13.8 ; 14.1 ; 14.2 ; 14.10 ; 14.12 ; 14.4 ; 17.3$; $18.1 ; 18.2 ; 20.3 ; 21.8$

Nigro: COR. 11.6

Numa Pompílio: Cor 39.11; ver Numa

Numa: CoR. $1.1 ; 25.2 ;$ ver Numa Pompílio

PANÁCTON: ALC. 14.4

Patras: Alc. 15.6

Pedanos: COR. 28.5

Pelida: Cor 32.6

Peloponésios: Alc. 27.4; 28.5; 28.9; 31.4; 31.8

Peloponeso: AlC. 15.2; 17.3; 23.1; Cor 14.6

Péricles: AlC. $1.2 ; 3.1 ; 6.4 ; 7.3 ; 14.2 ; 17.1$

PeritoÍdAs: $A L C .13 .4$

PILOS: ALC. I 4. I; COR 14.6

Pireu: ALC. 26.3

PisAndro: ALC. 26.1

Platão: AlC. 1.3; 4.4; COR. 15.4; COMP. Alc. COR 42.3

Platão-o-Cómico: Alc. 13.9

Plintérias: AlC. 34.1 
Pórcio Catão-o-Censor, Marco: Cor. 8.3

Póstumo: COR 11.5

Potideia: ALC. 7.3

Praxiérgidas: Alc. 34.1

Proconeso: ALC. 28.3

Próculo: COR 11.5

Ptolemeu látiro: Cor 11.3

Publícola: COR. 33.1; 33.2

Pulítion: AlC. 19.2; 22.4

Quios: ALC. 12.1; 24.1; 35.3

RÉGIO: ALC. 20.2

RoMA: COR. $1.1 ; 1.6 ; 3.1 ; 6.1 ; 13.6 ; 14.5 ; 14.6 ; 16.1 ; 24.1 ; 29.1 ; 31.7$; 33.1; 36.6; 39.7; COMP. ALC. COR. 43.2

Romanos: $\operatorname{CoR} 3.1 ; 4.4 ; 8.1 ; 8.2 ; 8.5 ; 10.4 ; 11.4 ; 19.1 ; 21.5 ; 22.3 ; 24.10$;

$25.5 ; 25.7 ; 26.1 ; 26.2 ; 26.3 ; 26.4 ; 26.5 ; 28.1 ; 28.3 ; 28.4 ; 29.2 ; 31.5$;

$33.1 ; 37.5 ; 39.10 ; 39.12$; COMP. ALC. COR 41.4; 43.2

Rufo: COR 11.6

SABINOS: COR. 5.2; 33.5

Salamina: AlC. 21.7

SAMOS: AlC. $25.3 ; 25.5 ; 26.1 ; 26.3 ; 27.2 ; 32.2 ; 35.8$

SARDES: ALC. 27.7

Selímbria: Alc. $30.3 ; 30.6 ; 30.7 ; 30.9$

Selímbrios: ALC. 30.10

Sesto: AlC. 36.6; 37.1

Sibírtio: ALC. 3.1

Sicília: ALC. $17.1 ; 17.2 ; 17.3 ; 19.4 ; 20.3 ; 24.1 ; 32.4 ;$ ALC. 39.8

Sicínio, Veluto: CoR. 7.2; 13.1; 18.3; 18.6; 18.8

Siracusa: AlC. 17.3; 18.7; COR. 16.1

SiraCUSANOS: ALC. $17.1 ; 22.1 ; 23.2$

SóCRATES: ALC. $1.3 ; 4.1 ; 4.4 ; 6.1 ; 6.5 ; 7.3 ; 7.4 ; 7.5 ; 7.6 ; 17.5$

SÓTER: COR 11.2

Sula: COR 11.6

SusÂMitres: ALC. 39.1

TARgÉLION: ALC. 34.1

Tarquínio-o-Soberbo, Lúcio: COR. 3.1

TÁUREAS: ALC. 16.5

Teano: AlC. 22.5

Tebanos: Alc. 2.6

Temístocles: Alc. 37.7; 37.8; COMP. Alc. CoR 41.6

Teodoro: AlC. 19.2; 22.4; 33.3

Teofrasto: Alc. 10.4 
Teоpompo: AlC. 32.2

TeOro: ALC. 1.7

TerÂmenes: Alc. $1.3 ; 31.5$

TÉssalo: AlC. $19.3 ; 22.4$

Teucro: AlC. 20.6; 20.7

Tideu: Alc. 36.6; 37.1

Timandra: AlC. $39.1 ; 39.7$

Timeia: AlC. 23.7

Timeu: Alc. 21.4; 21.6

Tímon-o-Misantropo: ALC. 16.9

TísIas: ALC. 12.3

TISSAFERNES: ALC. 23.5; 24.4; 24.6; 25.1; 25.2; 25.4; 25.5; 25.8; 26.1; 26.8; 27.6; 27.7; 28.2; COMP. ALC. COR. 41.9

TOlerinOs: COR. 28.5

TRÁCIA: ALC. 23.5; 36.3

TRÁcIOS: ALC. 30.9; 36.5; 37.7

Trasibulo: Alc. $1.3 ; 26.6 ; 36.1 ; 36.2$

Trasilo: Alc. 29.2; 29.3; 29.4

TRÁson: ALC. 36.1

TuCídides: ALC. 6.3; 11.2; 13.4; 20.6; COMP. ALC. COR 41.2

Tulo Átio: ver Átio, Tulo

Túrios: ALC. 22.1; 23.1

ULISSES: ALC. 21.1; COR. 22.4

VALÉRIA: COR. 33.1; 33.2; 33.7

VAlÉRIO, MÂNIO: COR 5.2

Veliternos: CoR. 12.4; 12.5

Vergília: Cor. 33.5; 34.1

Volscos: COR $8.1 ; 8.2 ; 9.7 ; 10.5 ; 12.6 ; 21.6 ; 22.1 ; 23.4 ; 23.7 ; 23.9$; $26.2 ; 26.3 ; 26.4 ; 26.5 ; 27.2 ; 27.3 ; 27.7 ; 28.1 ; 29.1 ; 30.6 ; 30.7 ; 31.1$; $31.2 ; 31.6 ; 31.7 ; 32.2 ; 34.1 ; 35.1 ; 35.7: 35.8 ; 36.6 ; 37.2 ; 39.2 ; 39.3$; 39.8; 39.12; COMP. ALC. COR. 41.4; 41.8; 43.2; 43.4

VolÚmNia: COR. $4.7 ; 33.3 ; 33.5 ; 33.7 ; 35.1 ; 36.1$

VOPISCO: COR 11.5

Xantipo: AlC. 1.2

Xenofonte: AlC. 32.2

Zeus Polieus: CoR 3.3

Zeus: ALC. 28.2; COMP. ALC. COR. 41.9; 44.2

ZópIro: ALC. 1.3 


\section{Volumes publicados na ColecÇÃo Autores Gregos e Latinos - Série Textos Gregos}

1. Delfim F. Leão e Maria do Céu Fialho: Plutarco. Vidas Paralelas - Teseu e Rómulo. Tradução do grego, introdução e notas (Coimbra, CECH, 2008).

2. Delfim F. Leão: Plutarco. Obras Morais - O banquete dos Sete Sábios. Tradução do grego, introdução e notas (Coimbra, CECH, 2008).

3. Ana Elias Pinheiro: Xenofonte. Banquete, Apologia de Sócrates. Tradução do grego, introdução e notas (Coimbra, CECH, 2008).

4. Carlos de Jesus, José Luís Brandão, Martinho Soares, Rodolfo Lopes: Plutarco. Obras Morais - No Banquete I-Livros I-IV. Tradução do grego, introdução e notas. Coordenação de José Ribeiro Ferreira (Coimbra, $\mathrm{CECH}, 2008)$.

5. Ália Rodrigues, Ana Elias Pinheiro, Ândrea Seiça, Carlos de Jesus, José Ribeiro Ferreira: Plutarco. Obras Morais - No Banquete II - Livros V-IX. Tradução do grego, introdução e notas. Coordenação de José Ribeiro Ferreira (Coimbra, CECH, 2008).

6. Joaquim Pinheiro: Plutarco. Obras Morais - Da Educação das Crianças. Tradução do grego, introdução e notas (Coimbra, CECH, 2008).

7. Ana Elias Pinheiro: Xenofonte. Memoráveis. Tradução do grego, introdução e notas (Coimbra, CECH, 2009). 
8. Carlos de Jesus: Plutarco. Diálogo sobre o Amor, Relatos de Amor. Tradução do grego, introdução e notas (Coimbra, CECH, 2009).

9. Ana Maria Guedes Ferreira e Ália Rosa Conceição Rodrigues: Plutarco. Vidas Paralelas - Péricles e Fábio Máximo. Tradução do grego, introdução e notas (Coimbra, CECH, 2010).

10. Paula Barata Dias: Plutarco. Obras Morais - Como Distinguir um Adulador de um Amigo, Como Retirar Benefício dos Inimigos, Acerca do Número Excessivo de Amigos. Tradução do grego, introdução e notas (Coimbra, CECH, 2010).

11. Bernardo Mota: Plutarco. Obras Morais - Sobre a Face Visivel no Orbe da Lua. Tradução do grego, introdução e notas (Coimbra, CECH, 2010).

12. J. A. Segurado e Campos: Licurgo. Oração Contra Leócrates. Tradução do grego, introdução e notas (Coimbra, CECH /CEC, 2010).

13. Carmen Soares e Roosevelt Rocha: Plutarco. Obras Morais - Sobre o Afecto aos Filhos, Sobre a Música. Tradução do grego, introdução e notas (Coimbra, $\mathrm{CECH}, 2010)$.

14. José Luís Lopes Brandão: Plutarco. Vidas de Galba e Otão. Tradução do grego, introdução e notas (Coimbra, CECH, 2010). 
15. Marta Várzeas: Plutarco. Vidas Paralelas - Demóstenes e Cícero. Tradução do grego, introdução e notas (Coimbra, CECH, 2010).

16. Maria do Céu Fialho e Nuno Simóes Rodrigues: Plutarco. Vidas Paralelas - Alcibiades e Coriolano. Tradução do grego, introdução e notas (Coimbra, $\mathrm{CECH}, 2010)$. 
(Página deixada propositadamente em branco) 

OBRA PUBLICADA

COM A COORDENAÇÁO

CIENTÍFICA

0

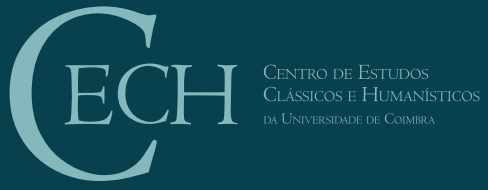

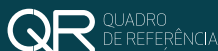
COMPETE

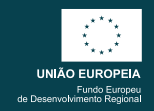

